\title{
Pántkarperecek a magyar honfoglalás korából
}

\author{
${ }^{1}$ MESTERHÁZY KÁROLY \\ 1e-mail: albeker.maria@t-online.hu
}

\begin{abstract}
MESTERHÁZY, K.: Band bracelets from the Hungarian Conquest period
Abstract: The author collected the material of ca. 250 find places by types. He examined the material, manufacturing technique, and chronology of the bracelets, as well as their distribution by social layers and gender, and their direct analogies in Russia and the Balkans. The ancient Hungarians of the Conquest period appeared in the Carpathian Basin with a new archaeological culture in the turn of the $9^{\text {th }}$ and the $10^{\text {th }}$ centuries. Band bracelets were characteristic pieces of this material culture. Today they are represented by three main types: 1 . band with rounded terminals, 2 . band with coiled terminals, 3 . hinged band. The first type has many variants. The terminal of the bracelet can be disc-like rounded, but mostly it just ends in a semicircular form. The band can be undecorated, decorated with punched palmette-tendril ornaments, or sometimes with geometric (zigzag) motifs, and applied decoration can also appear at the end of the band. In the beginning of the $11^{\text {th }}$ century only bronze bands occurred, with various punched dotted circle decorations. A punched hole can often be observed at both ends of the bands. This might have served for sewing the band on, however, others believe that a string threaded through the holes pulled the band together. The most frequent decorations of bracelets with coiled terminals are punched zigzag motifs, and sometimes palmette-tendrils also occurs. While the former type is frequent by both men and women, bracelets with twisted terminals rarely occur by men. Hinged bracelets either copied Byzantine antecedents, or they arrived as imports. The ends of the sleeves of the funerary dress, the cuffs were decorated by thin silver or gold ribbons that were sewed on the hem of the dress.
\end{abstract}

Keywords: band bracelets, Hungarian conquest period, chronology, decoration, main types of the bracelets

\section{Kutatástörténeti áttekintés}

Kereken 160 éve váltak ismertté az első honfoglalás kori karperecek. A verebi sírban a halott jobb oldalán, kezének elporladt csontjai között találtak rá egy gyűrüre, egy „ezüst nyílt karikára” és egy másik nyílt karikára sárgarézből. A leltár szerint az előbbi volt az ezüst pántkarperec, az utóbbi pedig a hegyesedő végű nyitott bronzhuzal karperec. ${ }^{1}$ A honfoglalás kori magyar sírleletek előkerülésének sorrendjében negyedik sírlelet karperece még rosszabbul járt. A szolyvai sír ezüst pántkarperecét ugyanis Lehoczky Tivadar fel sem ismerte. ${ }^{2}$ Fettich Nándor szerint a tegez alkatrészének nézte, ${ }^{3}$ és meg sem emlékezett róla. A nagyfokú bizonytalanságra maga Hampel mutatott rá első rendszerező munkájában, ahol még úgy látta, hogy „nem lehet mindig bizton tudni, hogy mi volt a rendeltetésük...csak akkor tételezhetö fel, hogy kar-vagy lábszár ékesítésére szolgáltak, amikor elég nagyok arra és amikor párosával jelentkeznek." Feltehető azonban, hogy e sorok a "Régibb középkor" első részének írása idején születtek meg, még 1894 elején vagy még előbb, és aztán változatlanul maradt a szöveg, mert a "Magyar honfoglalás kútfői"-be készült összefoglalás első változatában világosabban fogalmaz. ${ }^{5}$ Mai ismereteink szerint nyilvánvaló, hogy a véletlenül előkerült tárgyak helyes meghatározására csak szakszerủ feltárások után kerülhetett sor. Ennek tudható be, hogy Varázséji Gusztáv már 1880-ban helyesen írja le a szeged-öthalmi karpereceket, ${ }^{6}$ és Reizner János is saját tapasztalata alapján írt a bojárhalmi és királyhalmi leletekről.7 Másrészt az amatőr kutatók inkább egymás tapasztalataira támaszkodhattak, mint az éppen megszülető és alig hozzáférhető szakirodalomra. A Nemzeti Múzeumban dolgozó Nagy Géza mindkét lehetőséget kihasználva előbb saját tapasztalatokat szerzett Székesfehérváron, ${ }^{8}$ majd a következő évben (1893) már áttekintést is ad a honfoglalás kori temetkezésekről. ${ }^{9}$

ÉRDY 1857, 15; PULSZKY 1891, 10-12

2 LehoczKy 1870, 201-206; LehocZKy 1886, 379-380.

3 FetTICH 1937, 77.

4 Hampel 1897, 131.

5 HAMPEL 1895, 200.

6 VARÁZSÉJI 1880, 326-328.

7 ReIZner 1891, 102-104.

8 NAGY 1892, 299-315.

9 NAGY 1893, 224. 
Mivel a honfoglalás kori emlékek felismerése nagy vonalakban párhuzamosan folyt az avar hagyatékéval, a kezdeti időkben össze is keverték azokat. Amikor Hampel József 1892-ben Nagykátáról két karperecet vett leltárba, népvándorlás kor végéről valónak mondja mindkettőt, és pontosítva saját magát, korukat 8. századinak írja. ${ }^{10}$ Még jó, hogy egyúttal közli is az egyik karperec rajzát, és így egyértelmú a tévedése. Ennek oka pedig az volt, hogy szinte egyszerre Mártélyról is bemutattak egy pántkarperecet, melynek végein és a pánt közepén is volt egy rátétes dísz. Ez azonban később avar korinak bizonyult."1

De nemcsak a tárgyak felismerése és koruk megállapítása tartott el hosszabb ideig. Kalandos volt a karperecek egykori viselőinek maghatározása is. A verebi sírban a váz bal oldalán egy csomóban hat nyílcsúcs került elő. Ezért fel sem vetődött, hogy esetleg női sírra bukkantak. Sőt a rá következő száz évben sem vetődött fel ellenvélemény a halott nemével kapcsolatban. Csak 1962-ben gondolt Szőke Béla, éppen a karperecek jelenléte miatt arra, hogy a verebi sírban, vagy közvetlenül mellette egy női halottnak is lennie kellett. ${ }^{12}$ Ráadásul e feltevést rendszerszerúen kiterjesztve, megalkotta a páros (férfi és női) sírokból álló temetkezések csoportját. ${ }^{13}$ Pedig Érdy leírásából egyértelmű, hogy a lócsontváz (helyesebben lócsontok) alatt „egy ölnyi hosszú ember csontváz feküdt", és más csontokról nem esett szó. Ugyanakkor Pulszky Ferenc tapasztalata szerint a nyak és karperecek inkább a női sírok tartozékai, még ha az eddigi sírleletek bizonytalanságban is hagyják a kutatót. ${ }^{14}$

A következő negyven évben a honfoglalás kori sírok gazdag sorozata került elő, és jelentékenyen megnőtt a karperecet is tartalmazó temetkezések száma is. Ezért Hampel József, aki 1884 óta az Archaeologiai Értesítő szerkesztőjeként is egységesítette a régészeti szakszókincset, elvégezte a karperecek első rendszerezését, felosztását, tipológiáját. ${ }^{15}$ Az első rendszerezés, amely a későbbiekben is erőteljesen érvényesült, az 1890-es évekig előkerült anyagra épült, és annak a kornak a szemléletét tükrözi: a szarmata (a későbbi késő avar), az avar (a mai korai avar), és a magyar karpereceket együtt, formai alapon osztályozta. Ennek következtében eléggé zavarosnak ható leírások jöttek létre, melyek a példa darabok ábrázolásai nélkül ma már nehezen értelmezhetőek. A karpereceknek négy típusát különböztette meg. Az első csoportba tartoznak nála a kerek metszetű karikák, de ide sorolja a négyélű változatot is. A második (nála „b” típus) típusba sorolja azokat a kerek átmetszetű karikákat, melyeknek végei vagy egyenes lappal záródnak (pl. Cikó 356. sír karperece), vagy kiszélesednek, mint a szentendrei ezüst karperecek, melyeket ma kürtös végú típusként ismerünk. A harmadik csoportba (Hampelnél „c" típus) tartoznak a lemezkarperecek, az avar és magyar változatok egységként kezelve: Ordas és Mártély egyfelől, és a magyar sírok pántkarperecei másfelől, végződésükre való tekintet nélkül. Hampel a negyedik (nála ", $\mathrm{d}^{\prime)}$ típusba sorolta az állatfejes karpereceket, az ötödikbe (nála „e") pedig egyéb formákat, mint a sodronyból fonott (sodrott) és egyéb formákat. Alapvetően ugyanez a felosztás maradt meg a tíz évvel későbbi német nyelvű változatban, az „Alterthümer"-ben is. Csak ott több példát hoz az egyes típusokhoz, és mindegyik típust több ábrával teszi szemléletessé. ${ }^{16}$ Ezért, ha a jobb áttekinthetőségre vagyunk tekintettel, célszerúbb a német változatot használni. Ha a történeti szempontokat részesítem előnyben, nem mellőzhető "A régibb középkor" sem. Annál inkább sem, mert a két vaskos könyv megjelenése között, pont a félidőben készült el a honfoglalás millenniumára tervezett forrásgyűjtemény (1896/1900), amelyben Hampel a régészeti emlékek összefoglalásával szerepelt. ${ }^{17} \mathrm{~A}_{\text {, }}$ honfoglalási kor" emlékeinek vizsgálatakor a karperecek típusbesorolásánál ugyan figyelembe vette az előbb ismertetett tipológiát, de annak egyszerübb változatát mutatta be. Csak három fö csoportot különített el: „,...ismerünk egy vagy több szálból sodrott karikákat, vannak lapos, lemezespántú karikák, és vannak melyeknek fala gömbölyü vagy szögletes átméretü". ${ }^{18} \mathrm{~A}$ lemezes karperecek anyaga tapasztalata szerint rendesen ezüst, a pántok végződése szerint megkülönböztet kiszélesedő, néha körded alakot felvevő változatot, egyenesen levágott formát, mint a szeged-királyhalmit (aminek a vége valószínüleg letörött), és a végein kihajló karpereceket, melyek a példa szerint (Szeged-Bojárhalom, Nagykörü) a bepödrött végúek. A pántok lehetnek egyenletes szélességűek vagy kiszélesedők, simák, azaz díszítetlenek és pontkörös beütésekkel díszítettek (Kaba, Galgóc). A galgóciról azonban Fettich Nándor kimutatta, hogy a sírlelethez eredetileg, a leltár szerint, nem tartozott karperec, sem a pontkörös díszítésű, sem a kikerekedő és átlyukasztott végű darab. Sőt a pontkörös díszítésűről az is kiderült, hogy eredetileg a Ráth-féle gyújteményből keveredett a galgóci leletek közé. ${ }^{19} \mathrm{~A}$ pántkarperecekkel kapcsolatban Hampel egy fontos új megállapítást tett, miszerint ez a tí-

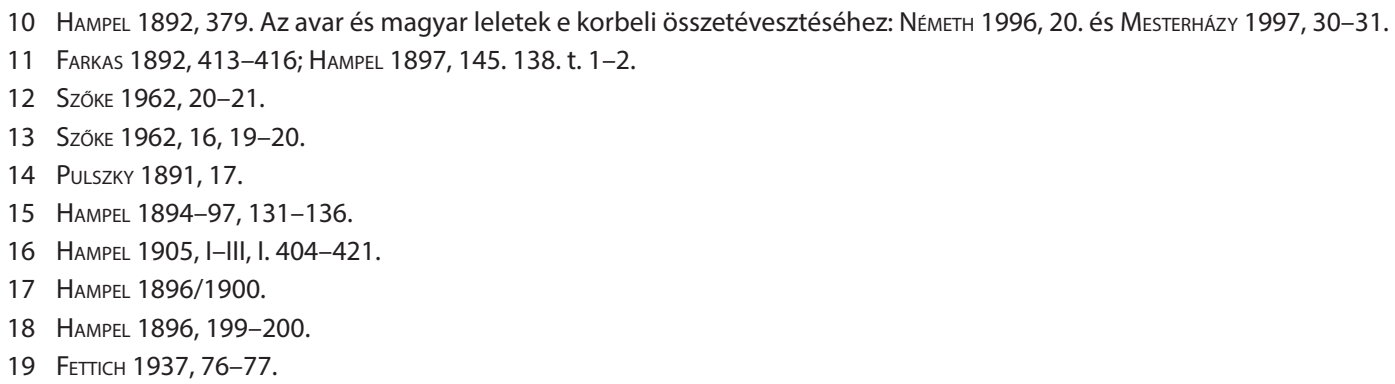


pus a kora középkori emlékek negyedik csoportjában, azaz a honfoglalás kori leletek között a leggyakoribb. ${ }^{20}$ Az időrendet tekintve ennél több nem is derült ki az addigi kutatásokból. Csak Hampel utolsó összefoglalásában találunk erre utalást, amikor is megjegyzi, hogy a pontkörös díszítésű karperecek néha a soros temetőkben is előfordulnak. ${ }^{21}$ Ezen felül csak olyan megfigyeléseket tett, amelyek további példák híján nem, vagy alig voltak általánosíthatók, pl. az oroszlámosi karperecek díszítése, vagy más egyedi jellegzetességek. Pósta Béla nyomán felveti, hogy ezek a karperecek nemzetközi forgalomból kerültek különböző népekhez. Egyebekben csak ismételte a korábbi megállapításokat. Érdekes, hogy nem tűnt fel neki, hogy az oroszlámosi karpereceknek akkor már két további párhuzama volt (Egyek, Nagykáta), sőt Oroszlámosról utánzatuk is ismert volt.

A Hampel utáni kutatás számára az egyes tárgytípusok érdektelenné váltak. Apró megfigyelések csak a sír- és tárgyleírások során történtek, azok is elszórva, alkalmilag. A karpereces sírok száma azonban jelentősen megnőtt. Már Fettich Nándor új ásatásain is számos példány került elő. A kenézlői, hencidai és más ásatások közlésekor a tárgyak leírása azonban nem mindig volt elegendő az élükre állítva fényképezett tárgyak típusának felismeréséhez. Ezeket a karpereceket a pántvég leírásának hiányában újra kézbe kell(ett) venni.0. Ebben a tekintetben Széll Márta rajzos táblái a szentesi temetők anyagáról megfelelőbbek. Mondhatnánk szerencsére, mert a sír- illetve tárgyleírások alapján néha egészen másra is gondolhatunk. Például a szentlászlói 87. sír egyetlen tárgyleírása sem egyértelmű, sőt félrevezető.. ${ }^{23}$ László Gyula munkásságában a karperecek csak mint a női viselet rekonstrukciójának elemei szerepelnek. A szeged-bojárhalmi nő ruházatán meg is találhatnánk azokat, ha karjait nem tenné a háta mögé. ${ }^{24}$

Az 1940-es évek elejéig a 10-11. századi ékszerek megnevezéseit a Hampel idejében rögzült formában használták. A hampeli munka folytatója, Szőke Béla azonban megújította, javította a terminológiát, és újabb tárgyneveket vezetett be. Az általunk vizsgált karperecekre összefoglalóan a jól bevált lemezes karperec kifejezést tartotta meg és használta. Ebben bizonyos fokig a készítési technika is kifejeződik. A honfoglalás kori sírokból a lemezkarperecek két fajtáját ismerte, a kikerekedő és pödört végű változatokat. A harmadik típus, a csuklós karperecek ekkor még csak két közöletlen darabbal voltak képviselve. Mindkét karperectípusnak összegyűjtötte a fontosabb lelőhelyeit (összesen 38 lelőhely), és az általa meghatározott temető illetve sírtípusokkal való kapcsolódásukat vizsgálta. ${ }^{25} \mathrm{Az}$ eredmények ugyan nem voltak egyértelmüek, mégis viszonylagos eligazítást adtak abban a tekintetben, milyen társadalmi csoportokban vagy rétegekben milyen karperecek várhatók a 10. század elején, a század végén, vagy a 11. század elején. Tapasztalata szerint a kikerekedő végű lemezkarperecek (26 lelőhely) leginkább a közép- és vezetőréteg első csoportjának (rozettás lószerszámos női sírok csoportja) sírjaiban fordulnak elő, de néhány darab köznépi temetőkben is található (4 lelőhely). Anyaguk főleg ezüst, de a köznépi temetőkben inkább bronz, sőt vas példányok is (Piliny-Sirmányhegy) fordulnak elő. A köznép körében a 10. század végétől válnak gyakoribbá, és ezek már pontkörös díszítéssel vannak ellátva (7 lelőhely). Szőke szerint ez utóbbiak a vezető réteg emlékeinek utánzásaként jelennek meg. Megemlíti, hogy néhány karperec kiszélesedő végein ütött lyukak vannak, de ennek értelmezésébe nem bonyolódik. ${ }^{26} \mathrm{~A}$ pödrött végű karperecek nyolc lelőhelyébő| ${ }^{27}$ arra következtetett, hogy a közép- és vezetőréteg második csoportjára jellemzőek (csüngős veretekkel díszített női ruha viselete). ${ }^{28}$ Ezek is főleg ezüstből készültek, de bronzból is előfordulnak. Viselőik Szőke leletstatisztikájából következően kivétel nélkül nők. Mivel a kikerekedő végű lemezkarperecek is zömmel női sírokból kerültek elő, feltételezte, hogy a férfi sírok karperecei meg nem figyelt női temetkezésekből származnak. Azaz eredetileg páros temetkezésekről lehet szó Vereb és más lelőhelyek esetében is. Véleménye szerint a koraiak a 10. század első feléből származnak és díszítetlenek, a díszített példányok pedig későbbiek. ${ }^{29}$

Szőke terminológiája és értékelése mind a mai napig tartja magát, és kisebb kiegészítésekkel, módosításokkal ezt használjuk valamennyien. Pedig azóta megsokszorozódott a hitelesen feltárt karperecek száma, újabb megfigyelések történtek a karperecek tipológiájára, viseletére, készítésére, időrendjére, származására vonatkozóan. Előbb nyilvánvalóvá vált, hogy a pántkarpereceknek van egy harmadik típusa is, a csuklós pántkarperec (Szarvas, Tiszaeszlár-Bashalom, Ártánd). Majd Szabó János Győző tett megjegyzéseket a karperecek anyagának

20 HAMPEL 1905, I. 413.

21 HAMPEL 1907, 67.

22 FеттісH 1937, 80, 85. t.

23 SzÉlL 1941, 241.

24 LÁszLó 1944, 153.

25 SZŐKE 1962, 71-72.

26 SZÖKE 1962, 71.

27 SZÖKE 1962, 72.

28 SZÖKE 1962, 24.

29 SzÖKE 1962, 95. Ezt követte KovÁCS 1989, 171. A bezdédi 18-as sír karperecével kapcsolatban vitatta IsTVÁNOviTs 2003, 312. A vita tárgyát két karperectípus azonos díszítésmódja indukálta. 
és időrendjének kapcsolatához. ${ }^{30}$ Az 1980 -as évek elején Kiss Attila gyűjtötte össze a teljesség igényével már mindhárom karperectípus lelőhelyeit és példányait. Alapforrása a "leletkataszter" volt, melynek adatait saját gyüjtésével is kiegészítette. Az alapforrás adatait mechanikusan vette át, így szerepel nála nem létező, illetve nem azonosított lelőhely, illetve a karperec típusa, díszítése, jellegzetességei csak autopszia útján deríthetők ki. Az általa gyűjtött lelőhelyek száma 179. A 10. és 11. századi lelőhelyek térképezését településtörténeti vizsgálatokhoz használta fel. ${ }^{31}$ Azóta Kiss Attila lelőhelylistája, illetve listái szolgálnak alapul húsz 10-11. századi tárgytípus elterjedéséhez.

Nagyjából Kiss Attilával egy időben foglalkozott a köznép (nála Bijelo Brdo-kultúra) ékszereivel Jochen Giesler. A karperecek időrendjére tipológiai besorolásukhoz volt szüksége. Megerősítette azt a felfogást, miszerint a honfoglalás kori környezet tovább élő formái a pödrött végü (nála 2. formaszámú) karperec, és a 3. számú, pontkörös poncokkal díszített pántkarperec. Ezek szerinte mind az ó-magyar horizonthoz, mind a Bijelo Brdo-kultúrához kapcsolódnak. ${ }^{32}$

A karosi, majd a Heves megyei honfoglalás kori temetők feldolgozásánál Révész László is Szőke Béla és Kiss Attila munkáit hasznosította, de Szőkével ellentétben saját gazdag ásatási példáira hivatkozhatott. ${ }^{33} \mathrm{~A}$ pántkarperec összefoglaló kifejezést használta, kiiktatva a lemez szót. Ennek következtében a készítési technikára kevesebb figyelmet fordítva bevezette, talán Bálint Csanád nyomán, az öntött pántkarperec meghatározást, ami azonban téves megállapítás. Másik nem szerencsés állásfoglalása a valódi karperecek és a vékony lemezből készült fémpántok összemosása. A közös szerepüket abban is megerősítve látta, hogy mindkét ékszer végein előfordulnak kis ütött vagy fúrt lyukak, melyek szerinte a viselet azonosságával magyarázhatók. A karperecek időrendjében és típusfelosztásában Szőkét követi, viszont jóval nagyobb a saját példatára több tekintetben is, így a férfiak és nők karperecviselésével kapcsolatban is. ${ }^{34}$

A legújabb szakirodalomban már gyakran Révész László összefoglalásaira hivatkoznak. ${ }^{35}$ Gáll Erwin az „erdélyi" pántkarpereceket egyetlen típusba sorolja négy altípussal (kikerekedő végű, pszeudorátétes, körponcokkal díszített és pödrött végü). ${ }^{36}$ Készítési technikájuk szerint megkülönböztet lemezből kivágott és öntött változatot. Vizsgálja az egyes altípusok elterjedését, nemek szerinti megoszlásukat, az egyes altípusok súlyát, időrendjét. A korábbiaktól eltérő keltezésre nem volt módja. Megismétli Révész megállapításait Varga Sándor is a keceli és homokmégy-székesi példányok kapcsán. ${ }^{37} \mathrm{~A}$ Szabolcs megyei Rétköz honfoglalás kori leleteinek közlésekor Istvánovits Eszter foglalkozott a karperecek e típusával. ${ }^{38} \mathrm{~A}$ Szőke-féle terminológiától eltérően ő is a pántkarperec kifejezést használja, és a terület hagyatékának példatárából kiindulva három altípust különböztet meg: a pödrött végű és kikerekedő végủeken kívül az eddig még fel sem bukkanó vas hornyolt oldalú változatot (Tiszabercel-Ráctemető 26. sír). Statisztikailag vizsgálja az egyes típusok számát, viseleti szokásokat, a karperecek anyagának kapcsolatát a társadalmi tagozódással. A szomszédos nyíri Mezőség emlékeit Tóth Anikó foglalta össze, gondosan számon tartva minden eddigi véleményt és megállapítást. ${ }^{39}$

A magyar kutatás viszonylag bőséges szemléje mellett szükséges lenne a témával foglalkozó külföldi szakirodalom áttekintése is, ahogy Szőke Béla is támaszkodott Zdeněk Vaňa, Lubor Niederle vagy Heinz Knorr munkáira. Erről azonban le kell mondanunk részint terjedelmi okokból, részint pedig a magyar kutatás eredményei ritkán érintették meg a külföldi kollegákat, és mi is ritkán reflektáltunk az ő tapasztalataikra. Így a pántkarperecek esetében csak példatárnak használjuk a külföldi szakirodalmat. Első feladatunk egy viszonylag teljes lelőhely adattár összeállítása. Ennek alapja mindenképpen Kiss Attila 1980 körüli adatgyüjtése. Adatait azonban egyenként ellenőrizni kell, részben mert hiányosak, és ezért kiegészítendők, részben mert pontatlanok, továbbá nem tett különbséget a valódi karperecek és a ruhaujjat díszítő lemezes pántok között. Azon felül az elmúlt negyven évben jelentékenyen megnőtt az új leletek száma. Bár a teljes lelőhelylista elérhetetlen, de a kimaradók száma 1-2 százaléknál aligha nagyobb, s közöttük nem várható olyan fontos egyedi példány, amelynek hiánya döntően befolyásolhatja a megfigyeléseket.

\section{Kikerekedő végü pántkarperecek}

Valójában többségében nem kikerekedő a végük. A kikerekedő végú típus is többféle.

A ritka változat pántja egyenletesen széles 10-14 milliméter között, és a két pántvég valóban kikerekedően

30 SZABÓ 1978-79, 51.

31 Fehér - Éry - Kralovánszky 1962; Kiss 1985, 232, 257-264.

32 GIESLER 1981, 88-89.

33 Révész 1996b, 91; Révész 2003, 435; Révész 2008, 415-416.

34 Bálint 1971, 51; Révész 1996b, 24, 30, 90.

35 GÁl 2013, 673-686.

36 GálL 2013, 208. kép.

37 VARGA 2016, 165, 289.

38 IsTVÁNOVITS 2003, 311-313.

39 То́тн 2014, 212-213. 
szélesedik ki. Van díszítetlen (Nagyszokoly: II. t. 1., Génye/Geňa), rátétdíszes (Mezőzombor-Bálvány-domb: I. t. 1, 3.) és poncolt díszítésű (Kiskunfélegyháza-Ferencszállás: I. t. 4.).

A második változatnak szintén egyenletesen 10-12 milliméter széles a pántja, a nyílt végek hosszan-oválisan szélesednek ki. Itt is gyakori a díszítetlen (Vereb, Neszmély) és a rátétdíszes (Nagykáta: I. t. 5., Egyek: III. t. 8., Kistokaj: III. t. 10., Oroszlámos).

A szakonyi kavicsbánya 1. sírjából olyan karperec került elő, melynek kiszélesedő vége nem lekerekített, hanem majdnem derékszögben záródik a pántvég (II. t. 8.).

Gyakori az a változat, amelynek viszonylag keskeny pántja 8-10 milliméter széles, és a végei hirtelen, tárcsaszerűen kerekednek ki. A végek kidolgozása/kiverése kevés gondossággal történt (Esztergom, "Galgóc”: II. t. 2., Karos II/45. sír).

Viszonylag széles pánt kettős karéjos kiszélesedő véggel. A pántvég középvonalában gyenge gerincelés látszik (Hencida 5. és 10. sír, Kőrösszegapáti-Pál-lapály, Galánta: III. t. 5., Gáva: II. t. 3.). Ennek díszített változata a Berettyóújfalu-B. Nagy János földjéről előkerült pántkarperec, amelynek végein poncolt palmetta látható.

Egyedi kialakítású a Békéscsaba-Erzsébethelyen talált karperec. A pánt végei felé összeszűkül, és „mandzsetta" közbeiktatásával gerincelt keskeny levél alakú díszítéssel zárul. Mandzsetta nélküli sima keskeny levél alakú végződése van egy hajdúböszörményi karperecnek.

Egyedi formája van a Budapest XX. kerületi Szent László úti karperecnek. A viszonylag keskeny pánt és a pánt szélességében kerek vég között egy-egy „farkasfog” elem az összekötő tag (III. t. 3.).

Enyhén kiszélesedő és kikerekedő pántja van egy három bordával díszített karperecnek (Győr-Újszállások: III. t. 7.).

Leggyakoribb a lekerekedő pántvég. Ennél a változatnál a pánt a végei felé többé-kevésbé kiszélesedik, de a pántvég egyenesen levágott, a sarkok azonban lekerekítettek. Díszítetlenek (Sajtény: Il. t. 10., Szentes-Borbásföld 14. sír) és díszítettek is előfordulnak közöttük. Poncolt díszítés van egy sajóládi pántvégen (I. t. 7.), és rátétes díszítése van egy madarasi karperecnek (I.t. 2.). Gyakori a teljesen egyenletes szélességű pánt, amelynek végei félkörben vagy kisebb ívben lekerekítettek (Sárrétudvari-Hízóföld 33. és 167. sír: II. t. 9., I. t. 8., Zalkod: Il. t. 6., Bánkeszi/Bánov 23. sír: III. t. 1., Szeged-Öthalom 41. sír, Sárospatak-Baksa-homok 2. sír, Csongrád, Szered/Sered 5/54. sír: Il. t. 5. stb.). Különböző szabálytalanságok a lekerekedő pántvégű karperecek esetében is előfordulnak. Egy Molnos/Mlynarce-i pánt a végei felé elkeskenyedik. Keskeny ezüstpántból készültek a szeged-domaszéki karperecek is, végeik inkább hegyesednek, a pántszélek szabálytalanok és eldolgozatlanok. Az egyik példány egyik végén ütött lyuk látható.

A pántok anyaga leggyakrabban ezüst vagy bronz. Néha azonban vasból is készültek (TiszabercelRáctemető). Egy esetben találkozunk arany lemezzel (Geszteréd: II. t. 4.), és egyetlen esetben borították be a bronz pántot aranylemezzel (Heves). De előfordul az aranyozott felületű ezüstpánt is (Karos III/9. sír). Az anyagnak nemcsak társadalmi-szociális mutató szerepe van, hanem bizonyos fokig időrendi különbséget is jelez. Az ezüst pántok a korábbi időre jellemzőek, a későbbi időre, értve alatta a 10-11. század fordulója körüli időket, már csak bronz példányokkal találkozunk. A pántkarperecek lemezből készülnek. Egyetlen kivétel az ártándi csuklós karperec. A lemezcsíkokból kivágott darabokat veréssel alakították ki. Az ezüstpántok többségét egyenletes vastagságú, 1-1,5 milliméter vastag ezüstlemezből készítették, és végeiket saját anyaguk vékonyabbra verésével alakították ki. Elsőként Fettich Nándor hívta fel a figyelmet arra, hogy a pántok a végeik felé vékonyodnak (pl. a hencidai karperecek esetében). ${ }^{40} \mathrm{~A}$ bronzpántok szintén lemezből vannak kivágva. Ez gyakran a pántok szélének eldolgozatlanságán is meglátszik (Nádudvar-Töröklaponyag). A pántok döntő többsége sima, díszítetlen. Néha azonban poncolt minta, esetleg a végeikre erősített rátét díszíti azokat. Apró vonalszakaszokból álló ponc-minta van a berettyóújfalui karperecen, hasonló poncmintából alakult a nagykátai karperec pántjának meg-megszakadó kettős vonalú farkasfog mintája, és szintén poncolt a sajóládi karperec díszítése is. A szob-ipolyparti temető 13. sírjának karperece bizonytalanul tartozik ide, hiszen a pántvéget nem ismerjük. A ritka kivételek közé tartozik a csekeji 401-es sír vékony pántja, rajta kettős vonalú X-ek sorával (III. t. 4.), és a Deszk-D temetőből való pánt „poncolt geometrikus díszítése” is.

Néhány karperecen hosszanti bordázás látható. Ilyen egy a győri Újszállásokról való aranyozott ezüst darab (III. t. 7.), amelyen két hornyolat fut végig, és a vaskarperec Tiszabercel-Ráctemetőből. Alsó és felső borda közt futó egyetlen hornyolat díszít egy karosi pántot (Karos III/9. sír). Ez a díszítésmód az avar korban is előfordul (Ordas, Bács-Kiskun megye). ${ }^{41}$

A ki- és lekerekedő végű pántkarperecek legszebb darabjai a végeiken rátétes példányok. Ma mintegy tucatot ismerünk: Berekböszörményből, Bajótról (ez már elveszett), Egyekről (III. t. 8.), Hevesről, Kistokaj-Gerendáról (III. t. 10.), Madarasról (I. t. 2.), Mezőzomborról (I. t. 1, 3.), Nagykátáról (I. t. 5.), Nagytőkéről, Oroszlámosról, Sarkadról, Vágvörösvár/Červenikről, van ahonnan többet is. Ez a díszítés csak az ezüst vagy az aranyborítású darabokon fordul elő. A pánt kikerekedő, többnyire ovális végére egy nagy, csepp alakú rátétet szegecseltek,

40 FETTICH 1937, 96.

41 RévÉSz 1996b, 35, 118. t. 18; Tergina 1880. 
esetleg felforrasztottak. Ez utóbbi lehetőségre egy nagytőkei (másként Szentes-Kunszentmártoni út) karperec végeinek lenyomata utal, ${ }^{42}$ valamint azok a rátétes karperecek, amelyeken a rátét felerősítésének nyoma, az aklaszeg nem látszik (Egyek, Sarkad, Nagykáta). Ezek esetében röntgenvizsgálattal meggyőződhetnénk a felerősítés technikájáról. Több esetben azonban világosan látszik a rátét szegecseléssel való rögzítése. Az egyik oroszlámosi példányról mind Hampel, mind Kovács László megjegyzi, hogy három-három szegecs látszik mindkét rátét alatt a pánton. ${ }^{43}$ Három-három szegeccsel erősítették fel a madarasi (I. t. 2.) és mezőzombori poncolt mintájú karperec díszítését is ${ }^{44} \mathrm{~A}$ madarasi karperec egyik rátétje már a temetés előtt elveszett, $\mathrm{s}$ itt a pánton jól látszik a három szeglyuk vagy furat. A másik rátét azonban a helyén van, csupán a rátét közepére behelyezett üvegberakás esett ki az idők folyamán. A harmadik szeglyuk pont az üvegbetét alatt van, tehát az ott levő szegecs nem a rátét felerősítésére szolgált, hanem az üvegberakás rögzítésénél lehetett szerepe. A másik mezőzombori, a vágvörösvári és a kistokaj-gerendai karperecen a rátét rögzítésére csupán két szegecset alkalmaztak, azaz itt két-két szeglyuk lenne a pánton, ha a rátétek leestek volna.

Ennél a pontnál érkeztünk el a kikerekedő végű pántkarperecek egyik nehezen értelmezhető jellegzetességéhez: a pántok végén több mint harminc esetben találunk egy-egy ütött/fúrt lyukat (Arad-Csálya, Biharkeresztes-Bethlen G. u.: III. t. 2., Csekej 401. sír: III. t. 4., Galánta-Papföld 6. sír, Gyulavarsánd-Laposhalom, szórvány: Il. t. 7., Gyulavarsánd-Laposhalom 1949/15. sír, Hencida 5. sír, Hertelendyfalva: III. t. 6., "Galgóc": Il. t. 2., Ibrány-Esbó-halom 197a. sír, Kál-legelő 10. sír, Karos III/6-os sír, Karos II/45-ös sír, Marosgombás-Kis Magura 10. sír, Ócsa-Alsópakony, Oroszlámos-Vasútállomás, Pétervására-Laktanya 1. sír, Sárrétudvari-Balázshalom, Sárrétudvari-Hízóföld 33. és 167. sír: Il. t. 9. és I. t. 8., Szeged-Öthalom 3. sír, Szentes-Borbásföld 14. sír, SzentesSzentlászló 74. és 95. sír, Szinyér, Szolnok-Beke Pál halma III/5. sír, Tiszanána-Cseh tanya 2. sír, Tiszapüspöki, Tiszakécske, Tiszavasvári-Aranykerti tábla, Várfalva 42. sír), néha két-két lyukat. Ez utóbbiak közé négy karperec tartozik: Bánkeszi/Bánov 23. sírjából (III. t. 1.), a karosi II/61-es sírból, Nagytőke-Jámborhalom, Németh Gergely földjéről és egy szórvány példány Mezőzomborról. A két-két szegeccsel rögzített rátétekhez két-két szegecslyukat kell ütni a pántba. Ezzel magyarázhatók a rátét nélküli 2-2 szegecslyukas pántok. De mire szolgálhatott egy-egy szegecslyuk? Erre több régészünk egymástól függetlenül azt a választ adta, hogy a karperecek végén levő lyukakba fonalat, László Gyula szerint egyenesen szalagot füztek a karperec összehúzására. Részben, hogy összehúzza a ruha ujját, részben pedig hogy a karperec le ne essen viselője kezéről. ${ }^{45}$ Már itt jelezzük, hogy valami nincs rendben ezzel az elképzeléssel, mert a karperecek zöme méreténél fogva fennmarad a csuklón. Példásan illusztrálja ezt a helyzetet a letkési II/67. sír, amelyben egy négy év körüli kisgyermek feküdt. A karperec pántvégei egymás felett zártak egy 52 milliméteres kört, és nem ütötték át a pántot, hogy a belefüzött huzallal összehúzzák a pánt végeit. ${ }^{46}$ Már ez is arra figyelmeztet, hogy a pántvégekbe ütött lyukaknak más szerepe lehetett. A hencidai 5. sírban csak a bal karon levő karperecen voltak lyukak, a másikról pedig hiányoztak. ${ }^{47}$ Ez azt jelentené, hogy csak a bal alkaron kellett összehúzni az ingujjat? További furcsaságot tapasztalunk három másik karperecen. A kál-legelői 10. sír karperecének egyik végén találunk lyukat. A másik karperecvég hiányosnak látszik. ${ }^{48}$ De az eger-szépasszonyvölgyi egyik bronz lemezkarperecnek szintén csak egyik végén van ütött lyuk. ${ }^{49}$ Egyetlen lyuk van a szeged-domaszéki egyik karperecen is, míg a másikon egy sincs. ${ }^{50}$ A geszterédi sírban is volt egy arany karperec, vagy inkább pótkarperec, amelyen szintén csak az egyik végen ütöttek egy lyukat. ${ }^{51}$ Bonyolítja a helyzetet három rátétimitációs karperec. Az ibrányi Esbó-halom 197a. sírjából való karperecen (III. t. 9.) a hátulról domborított rátétutánzat és a karperec széle közötti nagyon rövid felületbe ütötték bele mindkét végen a lyukat..52 A szeged-öthalmi 10/1950-es sír esetében is találkozunk ezzel a megoldással, ${ }^{53}$ és az egyik oroszlámosi karperecen is. ${ }^{54}$ Bizonyos mértékủ megoldást kínál egy széles, egyenletes pántszélességű, lekerekedő végủ ezüst karperec Sárrétudvari-Hízóföldről. A 167. sírban talált karperec mindkét végén a "szeglyukak" körül teljes körben az ezüstbe belenyomódott-belevert körgyűrủ van, de az egyik oldalon mélyebben, az ellenkező oldalon sekélyebben: mint a lemezes díszú nyergek szegeinek lenyomata az

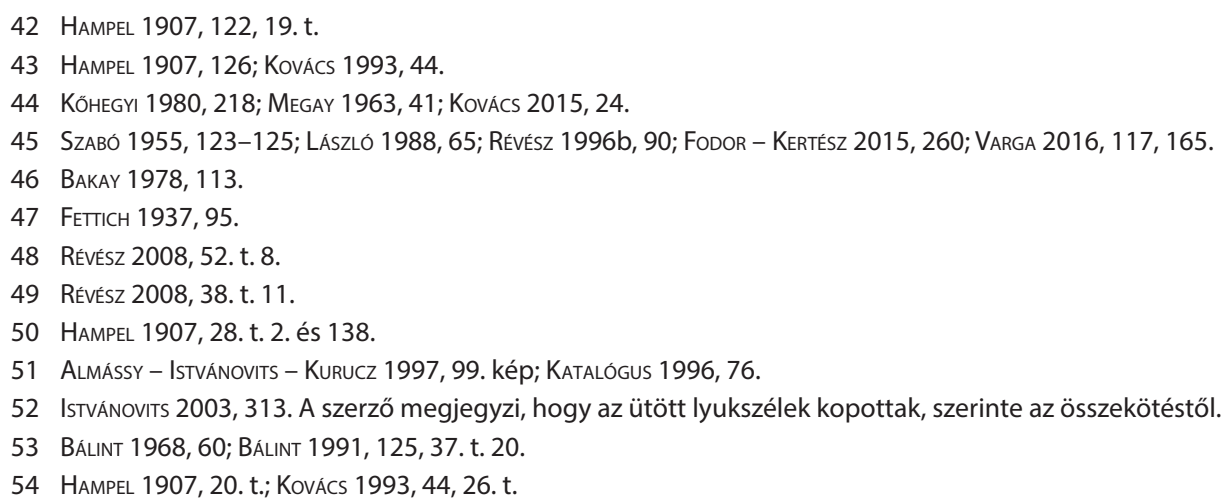


ezüstlemezeken. Itt talán valamilyen gömbfejű szegecs díszítette a pántvégeket (I. t. 8.). ${ }^{55}$ Hasonló szegnyom, szeglenyomat látható a karosi III/6-os sír karperecén is. Kár, hogy egyetlen karperec sem került elő még ezzel a díszítéssel. A magyarázatra egyelőre várnunk kell. Talán jobb régészeti megfigyelés vagy szerencsés néprajzi párhuzam megvilágíthatja ezt a jelenséget.

Az a feltevés is védhetetlen, hogy a ruha ujjának összeszorítására szolgálnának a karperecek. Ez az ötlet már Hampelnél felmerült, ${ }^{56}$ Szabó Kálmánnal folytatódott, ${ }^{57}$ majd újra egymástól függetlenül így vélekedik Kürti Béla, ${ }^{58}$ Fodor István.$^{59}$ Legújabban Szőke Béla nyomába lépve Révész László fejtette ki, ${ }^{60}$ és utána többen csatlakoztak hozzá: Gáll Erwin, ${ }^{61}$ Perémi Ágota, ${ }^{62}$ Türk Attila és Lőrinczy Gábor. ${ }^{63}$ Valamennyiüknek az volt a feltevés legfőbb érve, hogy a karperecek jelentős része a könyök alatt, vagy az alkar közepe táján volt a sírban. Jellemző azonban, hogy egyetlen nő sem csatlakozott a gondolathoz, vagy legalábbis a jelen érvekkel bizonyíthatatlannak érezte. Ellenérveket viszont csak Langó Péter vetett fel. ${ }^{64} \mathrm{~A} 19$. századi kazah viselet archív felvételei is azt mutatják, hogy akár négy pántkarperecet is viselhetett egy nő egyidejüleg a karján, de a ruhára ráhúzva egyetlen példát sem találtam. ${ }^{65}$ Nem mellékesen azt is meg kell jegyezni, a halottak nem viselik az ékszert, azokkal a temetést előkészítő családtagok látják el őket. Nagyon tanulságosnak vélem az ibrányi temető 194. sírjában nyugvó halott karperecének helyzetét: a halott jobb kezét a vállához húzták fel, és a jobb kéz karperece a jobb könyökhöz csúszott le eközben. ${ }^{66}$

A rátétdíszes karperecek a legigényesebb darabok közé tartoznak. Néha előfordul, hogy a rátétet önállóan használják fel. Szolnok-Lenin tsz. lelőhelyről közöl egy ilyen darabot Madaras László, bár eredeti szerepét nem ismerte fel. ${ }^{67} \mathrm{Az}$ igényes ékszereket olcsóbb kivitelben utánozni is szokták. A pántkarperecek között is több imitált rátétes példány fordul elő. Egy gyulavarsándi karperecen a pántvégeken fekvő $V$ alakú préselt díszítés fogja közre a pánt két oldalát, és középen szintén préselt csepp alakú díszítés foglal helyet, ezzel egy rátétet utánozva. ${ }^{68}$ Solton, Szeged-Öthalmon, Oroszlámoson, Ibrányban (III. t. 9.) vagy az egész rátétet egyetlen csepp alakú, hátulról domborított díszítéssel utánozzák, vagy a csepp alakzat körvonalát jelzik hátulról domborított hólyagocskákkal. A legszebb díszítés kétségtelenül a poncolt indával kitöltött mezőzombori és ferencszállási pánton látható, melynek leegyszerúsített változataival majd a pödrött végű pántkarpereceken találkozunk.

Még egy mintáról meg kell emlékeznünk, amely föleg a bronz pántokon fordul elő: ez a pontkörös vagy egyszerü, apró egymásba írt-ütött körökből álló díszítés. Majdnem harminc lelőhelyről ismert. Ezek közül egynek az anyaga ezüst (Letkés II/67. sír: IV. t. 6.), illetve van még két másik ezüstkarperec is, de azok már pödrött végüek (Kistokaj-Gerenda 4. sír: IV. t. 9., Bezdéd 14. sír). Az utóbbin nem pontköröket látunk, hanem egyszerű beütött kis karikák sorait. Ha a díszítés egységeit vizsgáljuk, akkor legalább négyféle változatot találunk. Van pusztán beütött kör (Bezdéd), négyszeres koncentrikus kör (Kaba), hármas koncentrikus kör (Püspökladány-Eperjes 521. sír: IV. t. 3.), kettős egybeírt kör középen ponttal (Körösszegapáti: IV. t. 4., MezőkovácsházaTemplomföld: IV. t. 5., Hajdúszoboszló-Árkos-halom 14. sír, Dunaszekcső, Fábiánsebestyén-Molnár F. F. földje: IV. t. 1.). Ha a beütött körponcok rendszerére vagyunk tekintettel, akkor van egysoros (Taktaharkány-Bazsi, Gyulafehérvár-Brandusei u. 137. sír, Mezőkovácsháza, szombathelyi múzeum-ismeretlen lelőhely, SzegedMakkoserdő 13. sír, Püspökladány-Eperjes 521. sír), kétsoros (Csákberény-Öregtó, Nádudvar-Töröklaponyag 20. sír: IV. t. 2., Körösszegapáti-Pál-lapály 6. sír: IV.t. 4.), és háromsoros (Bezdéd 14. sír, Brestovik) díszítés. A kiszélesedő pántvégek díszítésének rendszere is jellegzetes. Az egyszerū pontkörös egységekkel díszített karperecek elterjedése egy laza sűrűségű alföldi csoportot rajzol ki, melyhez Bakonszeg-Kovácsi és Nádudvar-Töröklaponyag tartoznak egyfelől: a kikerekedő végeken 3-3 ponc a széleken, alul-felül-középen és utánuk két sorban alul és felül, és másfelől Fábiánsebestyén-Molnár F. F. földje, Kaba, Csanytelek-Dilitor 61. sír karperecein 3-3 ponc a kiszélesedő végeken, utánuk pedig egy sor van a pánton. Hasonló elrendezésü, de nem szimmetrikus a poncok elhelyezkedése a nagykapornaki és taktaharkányi pántokon. Teljesen szabálytalan a beütések elhelyezése az egysoros csöllei/rovinkai (IV. t. 8.) és a Hajdúszoboszló-Árkos-halmi 14. sír karperecén. Stilizált indát alakítottak

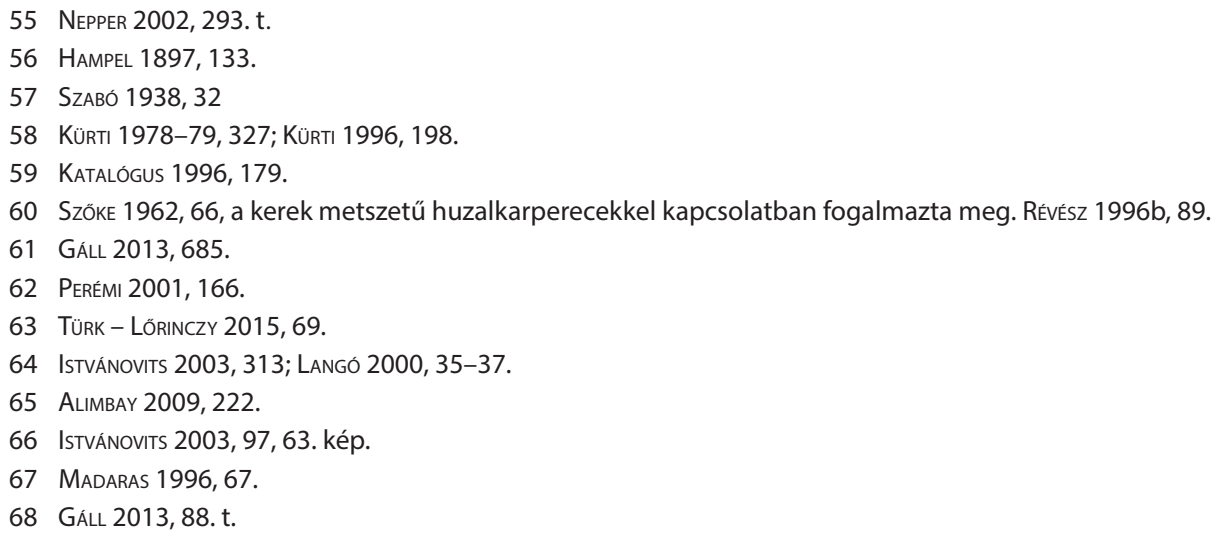


ki a Homokmégy-székesi 229. sír karperecének pántján (IV. t. 7.). A pántvégeken ennél a típusnál is előfordul az egy-egy ütött lyuk (Várfalva 42. sír: IV. t. 10., Homokmégy-Székes 229. sír).

Időrend. A kikerekedő végű pántkarpereceket általában a 10. század első két harmadára szokás keltezni. ${ }^{69}$ Pénzzel keltezett sírlelet a verebi, Berengár imperator (915-924) denárával. ${ }^{70}$ Hasonló korú a neszmélyi karperec, szintén Berengár imperator pénzével. ${ }^{71}$ Szered II. temetőjének 8/55-ös sírjában Henrik német király (919-936) pénze keltezte a karperecet. ${ }^{72}$ A szeged-királyhalmi leletben (mai neve Ásotthalom-Rívó) Ismail ibn Ahmed szamanida emir 905/906-ban vert dirheme volt. ${ }^{73}$ Sárospatakon, a baksahomoki 2. sírban Nasr ibn Ahmed szamanida emir 918/919-ben vert dirhemét találták. ${ }^{74}$ Jánoshalma-Kisrátán a karpereces sírral szomszédos sírban Theophilos és II. Mihály valamint Constantin társcsászárok közös uralkodása alatt (832-839) vert 1/2 solidus került elő. ${ }^{75} \mathrm{~A}$ pénzek keltező értéke azonban mindaddig viszonylagos marad, amíg nem rendelkezünk elegendő számú zárt lelettel, amely megfelelő életkor adatokkal kombinálva a 10. század első évtizedeitől keltezi a sorozatokat. A szeged-királyhalmi és sárospatak-baksahomoki karperecek jól jelzik, hogy ezzel a típussal már a honfoglalástól számolhatunk, ha egyelőre nincs is korábbra biztosan keltezhető darabunk, és hiányzanak a Kárpátoktól keletre levő sírleletekből. Az bizonyos, hogy Kiss Attila nem kételkedett abban, hogy a pántkarperecek a honfoglaló magyarokkal kerültek a Kárpát-medencébe. ${ }^{76} \mathrm{~A}$ kelet-európai, nem magyar karperecek között azonban vannak egészen jó formai párhuzamok is, például a rátét díszes típusból, melyekre már jóval korábban felfigyeltek. ${ }^{77}$ Ilyen egy kocserginoi bronzkarperec, amelynek pántjai végén olyan ovális-csepp alakú rátét van, mint a magyar pántkarpereceken. A birituális temető feltehetően egy volgai finnugor néphez kapcsolható. ${ }^{78} \mathrm{~A}$ már magyarnak mondható Szubbotyici temető 1. sírjában is volt egy bronzkarperec, amelynek pántja középvonalában gerincelt volt, a végei pedig egy kis becsípett vállból enyhén kiszélesedve kerekedtek le. ${ }^{79} \mathrm{~A}$ hazai anyagból közel áll hozzá a Nagytőke-Jámborhalmon, Némedi Gergely tanyáján előkerült karperec, amelynek szintén lapos háromszög metszetű a pántja, azaz gerincelt. ${ }^{80} \mathrm{~A}$ korobcsinói karperec pedig egyesíti a hevesi és a békéscsaba-erzsébethelyi pántok jellegzetességeit: a bronz pánt aranylemezzel van beborítva, a pántvégeken pedig hosszú, ovális foglalatban rubin kő ül.81 Így mind a legkorábbi pénzzel keltezett sírok, mind a keleti párhuzamok arra mutatnak, hogy a kikerekedő végú pántkarperec minden változata a magyarokkal jelent meg a Kárpát-medencében. Keltezésük általában a honfoglalástól számítható még akkor is, ha az egyes sírok anyaga nem ad lehetőséget évtizednyi pontos kormeghatározásra. A legkésőbbi példányok már bronzból készültek, és rajtuk pontkörös vagy koncentrikus poncbeütések láthatók. Szőke Béla még csak hét lelőhelyüket sorolta fel, ma harminc körül van a számuk. ${ }^{82}$ Gyulafehérváron a Brandusei utca 137. sírjában Szent István és András pénzével együtt találták. ${ }^{83}$ Hasonló korú lehet a fábiánsebestyéni (Molnár F. F. tanya 4. sír) darab is, a mellette levő 5. sírban szintén András denára voltt. ${ }^{84}$ Közbenső korú Csanytelek-Dilitor 61. sír karperece, amely Szent István denárának negyedével került elő. ${ }^{85} \mathrm{~A}$ bezdédi 14 . sír a kerek poncokkal díszítettt karperece alapján a temető legkésőbbi sírja is lehet, de mindenképpen korábbi a 10. század végénél. A többi pontkörös díszítésű karperec e két végpont közé keltezhető. Sajnos, a köznépi temetkezések legkorábbi pontkör poncos karperecei szórványok, vagy még az Árpád-kori pénzek sírba kerülése előtti időből származnak (Nádudvar-Töröklaponyag 20. sír, Homokmégy-Székes 229. sír, Letkés II/67. sír, Várfalva 42. sír, PüspökladányEperjes 521. sír, Hajdúszoboszló-Árkos-halom 14. sír). A letkési karperec anyaga ezüst, a pánton két sorban fut körbe a pontkörös ponc díszítés. Ezzel összekötő kapocs a középréteg és a köznép ékszerviselete között. A sír kora a 10. század utolsó harmada lehet, de a sírban levő két $\mathrm{S}$ végű hajkarika nem segíti a keltezést. ${ }^{86}$ A hajdúszoboszlói Árkos-halom 14. sírjának karperece szintén a temető 11. század eleji sávjából került elő. Így

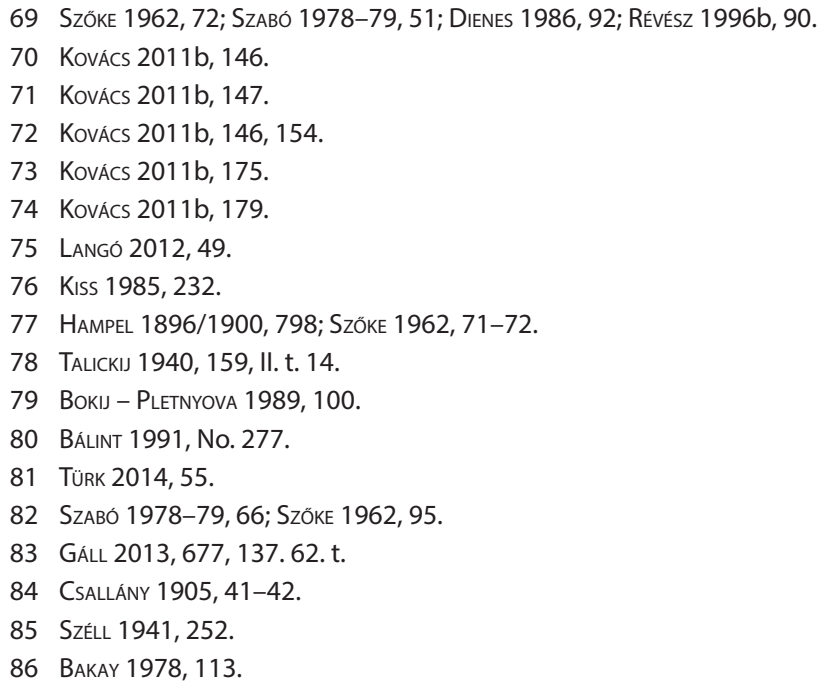


az utóbbi fél évszázad ásatásai megerősítették a pontkörös díszítésű karperecek Szőke-féle keltezését. Mindez annak ellenére is igaznak látszik, hogy maga a pontkörös díszítés a honfoglalás kori tárgyakon jóval korábban feltűnik. Nincs szükség nagy tárgybemutatóra e tekintetben, de a számos tegezszáj agancsléc, ${ }^{87}$ csonteszköz, $_{1}^{88}$ különböző gyűrűtípusok ${ }^{89}$ díszítése erről tanúskodik. Erre vallanak a 10. századi Cherson városának hétköznapi tárgyain is gyakori pontkör-díszítések, melyek korai forrásként jöhetnek számításba a honfoglaló magyarok díszítőművészetében. ${ }^{90}$

A kikerekedő, de legalábbis nem bepödrött végü karperecek szinte elmaradhatatlan kellékei a rozettás lószerszámos női síroknak. Erre külön felhívta a figyelmet Szőke Béla. A karosi temetők anyaga megerősítette ezt a megfigyelést. A második és harmadik karosi temető összesen 23 pántkarperecéből csupán két darab pödrött végű, a többi a Szőke-féle statisztika szerint kikerekedő végű típus. Valamennyi ezüstből készült. A két bronz pödrött végű változat azonban jelzi, hogy az egyes csoportok nem különülnek el élesen egymástól, hanem átjárhatóak. Ugyanígy a nemek szerinti megoszlás sem követ megváltozhatatlan szabályosságot. A karosi II. és III. temetőben ugyan főleg a női sírok ékszerei voltak a pántkarperecek, de itt sem kizárólagosan, hiszen a II/61. és III/13-as sírban férfiak voltak.

\section{Pödrött végü pántkarperecek}

Az első pödrött végű pántkarperec tudomásunk szerint a szeged-bojárhalmi sírból került elő 1889-ben, és eléggé körülményesen írta le Reizner János: „....s a nyílásnál a pánt végei egy kis karikára visszahajlítvák." ${ }^{\prime \prime 1}$ Néhány év múlva, 1892-ben találták a székesfehérvári Demkóhegyen az 5. sírban azt az ezüst karperecet, amely „négy darabra tört s egyik végén kifelé csavarodó" volt. ${ }^{92}$ Még Hampel is körülírással mutatta be a honfoglalás kori karperecek e típusát: "amelyeknek a végei tekercsszerüen kifeléfordulnak”, és zsineg vagy sodrony segítségével voltak összefoglalhatók. ${ }^{93}$ 1907-ben a pántos karperecek harmadik főváltozatának mondta azokat, „,amelyeknek nyílt végei hengerded tekerccsel fejeződnek be.."94 Ez után hosszú ideig alig esik szó a pödrött végü karperecekről. Jellemző, hogy az 1941-ben közölt szentes-szentlászlói 82. sír kapcsán a típus pontos megjelölése el is maradt, csak a rajzos tábláról derül ki, hogy miről is van szó. ${ }^{95} \mathrm{~A}$ máig érvényes terminológiát ez esetben is Szőke Béla alkalmazta. Megállapításait ma is használjuk. Jellemző, hogy leletstatisztikájában összesen csak nyolc lelőhelyet sorol fel, majd ezeket további kettővel egészíti ki (Bezdéd, Piliny), és ezek alapján jellemzi a tárgytípust. ${ }^{96}$ E típusnál is a díszítetleneket véli korábbinak, a díszítetteket pedig későbbinek. Az előbbieket a 10. század első kétharmadára keltezi, a díszítetteket a harmadik harmadra. Leletstatisztikájából egyértelmű volt, hogy a női sírokra jellemzők, és a "csüngős veretekkel jellemzett" viseletben eltemetett nők körében gyakoriak. ${ }^{97}$ A régészeti kutatások a Szőke számára rendelkezésre álló leletmennyiséget megtöbbszörözték, és Kiss Attila már 45 lelőhelyet jelölt meg településtörténeti munkájában. ${ }^{98}$ Ez a szám azt jelzi, hogy a pántkarpereceknek kb. a negyede (25\%) pödrött végü. Jochen Giesler csupán annyiban érintette a pödrött végű karperecek kérdését, amennyiben azok átvezetnek a honfoglalás kori lelettípusok közül a Bijelo Brdo-kultúrához. De nem tartoznak a Bijelo Brdo-kultúra ékszerkészletéhez. ${ }^{99} \mathrm{Ez}$ azért fontos, mert eközben a magyar kutatók sora a köznépi temetőkkel való szoros kapcsolatukat hangsúlyozták. Míg tehát a kikerekedő végű, zömmel ezüst karpereceket az előkelő réteg viseleti darabjaiként ismerték el, a pödrött végű karpereceket a köznépi ékszerek közé sorolták, ahogy azt Szőke Béla megfogalmazta: főleg a köznépi temetőkre jellemző a pödrött végü karperec. ${ }^{100}$ Valójában arról volt szó, hogy a lelőhelyek közt köznépi temetők is voltak, de a karpereces sírokban nem a köznép szegényei nyugodtak.

87 Straub 1999, 410-414.

88 Wolf 2016, 650.

89 Demo 2009, II. 520; KeSZI 1990, 133, 137; Bollók 2015, 329-331.

90 YashaYeVA 2010, 208-209.

91 ReIZNER 1891, 104.

92 NAGY 1892, 306; BaKay 1965-66, 47.

93 HAMPEL 1897, 133, három példát mutat be, Szeged-Bojárhalom, Székesfehérvár-Demkóhegy és az 1893-ban közölt nagykörűi pántkarperecet. Ugyanakkor nem említi az 1896-ban ismertté vált bezdédi példányt. Ezért valószínű, hogy "A Régibb középkor” II. kötete is jórészt készen állt 1894-ben, az első kötet megjelenése évében.

94 HAMPEL 1907, 67.

95 SzÉLL 1941, 241.

96 SZÖKE $1962,72,96$.

97 SZÖKE 1962, 24.

98 KISS 1985, 257-264.

99 GIESLER 1981, 88-90.

100 SZÖKE 1962, 72; KISS 1985, 232; KovÁCS 1989, 171; RÉVÉSz 1996b, 91. 
Kovács László a nagyhalász-zomborhegyi ásatása kapcsán megkísérelte a pontosabb keltezést, és felsorolta a pénzzel keltezhető sírokat, és tágabban véve a pénzt és pödrött végú karperecet tartalmazó temetőket. ${ }^{101}$ Az eredmény természetesen nem volt egyértelmű, és az a próbálkozása sem volt az, hogy kizárólagosan a női ékszerviselet tartozékának tekintsük a pödrött végú pántokat. ${ }^{102} \mathrm{~A}$ karosi temetők mindezekben a kérdésekben semlegesek maradtak a jelzett karperecek kis száma miatt. Inkább megerősítették Szőke Béla véleményét. Ennek ellenére egy érdekes keltezési szempont rögzült, amely széles körben elismerést nyert. Ez a bepödrött végü pántkarperecek 920 körüli feltűnésének keltezése. ${ }^{103}$

Jelenleg majdnem nyolcvan lelőhelyről tartunk számon pödrött végű karperecet, és ezeknek mintegy a fele készült ezüstlemezből, a másik fele pedig bronzból. Nincsenek köztük öntött darabok. A lemezek szélessége 0,5-1,4 centiméter között változó. A pántok vége lehet egyenletesen széles, de többnyire a pántvég felé keskenyedik, és ez a szakasz van bepödörve. Ritkán előfordul azonban olyan változat is, amikor a le- vagy kikerekedő végű pántok végét hajlították ki (Kecskemét-Lakihegy B. sír, Szob-Kiserdő 66. sír, Középhídvég/mai nevén Tengelic). ${ }^{104}$ A pántok zömmel díszítetlenek, de vannak poncolt mintázatú karperecek is. A pontkörös vagy csak többsoros körponc ritkán fordul elő (Bezdéd 14. sír, Galánta: VI. t. 3., Kistokaj-Gerenda 4. sír: IV. t. 9., Kistokaj-Gerenda 45. sír: V. t. 10.). ${ }^{105} \mathrm{Nem}$ túl gyakori a rezgő vonalú (tremolírozott) háromszög és összetett geometrikus minta sem: Biharkeresztes-Bethlen G. u. (VI. t. 6.), ${ }^{106}$ Kistokaj-Gerenda 17. sír (V. t. 9.), ${ }^{107}$ MiskolcReptér 4. sír (V.t. 7.), ${ }^{108}$ Sóshartyán-Hosszútető 30. sír (V. t. 3.), ${ }^{109}$ Csekej/Čakajovce 336. sír (VI. t. 5.). ${ }^{110} \mathrm{~A}$ leggyakoribb díszítés a páros vonalú szaggatott háromszög sor, a zeg-zug minta, amely a piliny-sirmányhegyi temető karperecein kétszer fordul elő (5., 58. sír), ${ }^{111}$ Ipolykiskeszi/Male Kosihy 301. sírjában (VI. t. 4.), ${ }_{112}^{112}$ de a legtöbbször Kistokaj-Gerenda 5., 34. (V. t. 8.), 58. sírjában,, ${ }^{113}$ Püspökladány-Eperjesen a 450. sírban, ${ }^{114}$ Zsitvabesenyő/ Bešeňov-Sírdülő 30. sírban (V. t. 1.). ${ }^{115}$ Ennek változata a poncolt többszörös hullámvonal a pánt hosszában: Szőreg-Homokbánya (V. t. 5.). ${ }^{116}$ A karperec pántjának alsó és felső széle mentén poncolt vesszősor húzódik a karosi II/73. sír és a zsitvabesenyői 107. sírban. ${ }^{117}$ Befejezetlen palmettás inda látható a pilinyi Sirmányhegy 56. sírjának karperecén, ${ }^{118}$ és sematikus indával díszítették a kecskemét-lakihegyi B. sír pántját (VI. t. 1.). ${ }^{119}$ Szép kivitelü az inda a gényei karperecen (VI. t. 2.). ${ }^{120}$

Itt merül fel azonnal a keltezés kérdése. A pénzekkel keltezett sírok közül első pillantásra is számításon kívülre kerül a sóshartyán-hosszútetői karperec, melyet Kegyes Lajos (814-840) denára „keltez". ${ }^{121}$ A perse-bérci 101. sírban viszont Nasr ibn Ahmed emir al Muktadir kalifa uralkodása alatt (908-932) vert dirheme volt. ${ }^{122}$ AldebröMocsáros 20. sírjában a pödrött végú pántok Provencei Hugó (926-931) denárával együtt kerültek elő. ${ }^{123}$ A kistokaji 58. sírban talált karperecet a szomszédos 53. sír Ismail ibn Ahmed 906/907-ben vert dirheme keltezte. ${ }^{124} \mathrm{Ha}$ ezekhez hozzávesszük még az orosházi Nagy Albert tanyánál feltárt sírt, amelyben Provencei Hugó és II. Lothar (931-947) érme volt, ${ }^{125}$ akkor ezekből az adatokból nehezen lehet a 920-as éveket kikövetkeztetni. Más adat pedig a többi pénzzel keltezett temetőből sem adódik. A feltételezés út(já)ra indítója Szabó János

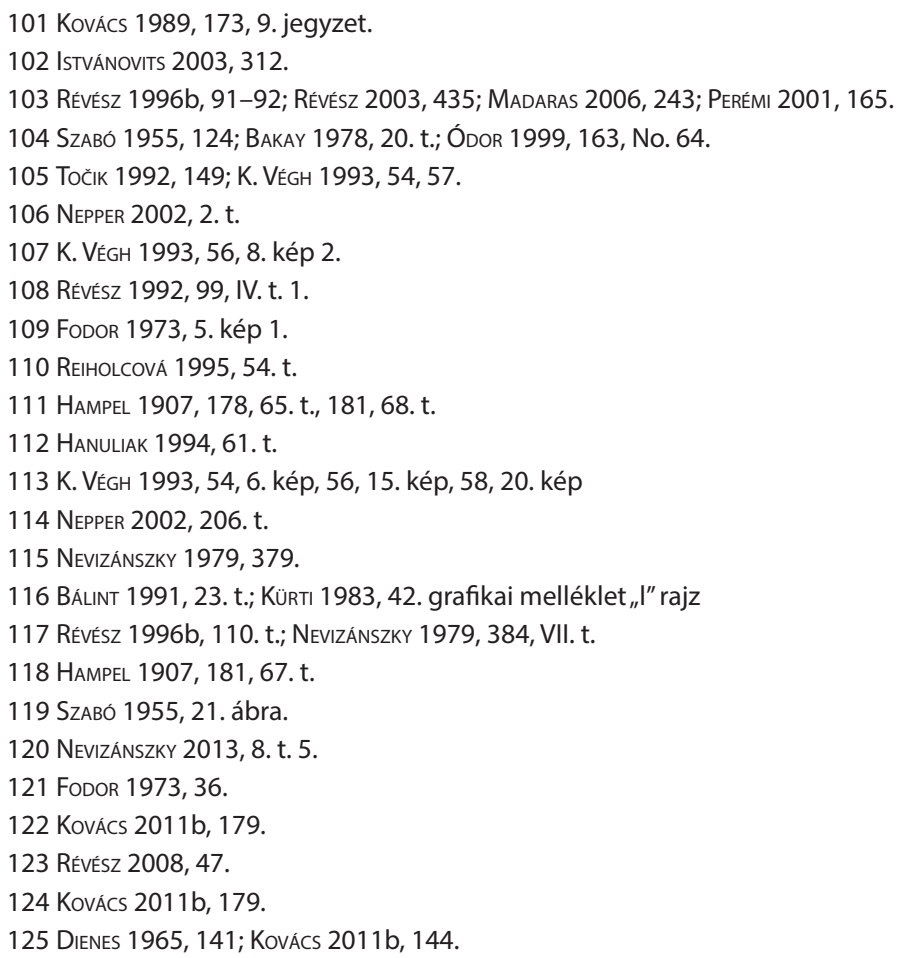


Győző volt, aki a sodrott huzalú és spirálisban záródó karpereceket igyekezett Szőke Bélánál pontosabban keltezni. Az aldebrő-mocsárosi 13. sír karperecei olyan temetőből kerültek elő, amelyben csak két Provencei Hugó érme volt. ${ }^{126}$ Ezt a keltezést tartotta a spirálissal kitöltött végű sodrott karperecek számára reálisnak Langó Péter is. ${ }^{127}$ Az aldebrői 13. sírban levő pödrött végű karperec ezek után automatikusan kelteződött a másik karpereccel azonos évekre. ${ }^{128}$ Azzal a megszorítással tetézve, hogy biztosan honfoglalás előtt készült tárgyakkal együtt sem került még elö. ${ }^{129}$

Valójában tehát itt is ugyanolyan bizonytalanságban vagyunk, mint a kikerekedő végű karperecek esetében, és egyúttal a legtöbb 10. századi tárgytípusunk esetében. Pedig célszerű arra gondolni, miért éppen a 920-as évek lennének egy sor új tárgytípus feltűnésének évei. Nagyon valószínű, hogy ez a karperec is keleti hozadék, csak ki kell várni az egyértelműen honfoglalás előttre keltezhető darabok előkerülését, akár keleten, akár itthon. Jelzés értékűnek tartom, hogy a Kosztroma környéki kurgánokban, Moszkvától kb. 250 kilométer távolságban északkeletre, a 11. század elején minden lényeges pántkarperectípus előfordul, a kikerekedő végűek, a bepödrött végűek és más formák is. Nem valószínű, hogy ott újra feltalálták ezeket a formákat. ${ }^{130}$

Ami pedig a díszítettséget illeti, ennek időrendi besorolását a kistokaji nyolc pödrött végü karperec alaposan megváltoztatta. Teljesen nyilvánvaló, hogy a 10. század első harmadában is előfordultak díszített példányok, és használatuk párhuzamosan futott a díszítetlen pántokéval. Azt azonban nem tudjuk, hogy a díszítetlen karperecek valóban korábbiak-e, mint a díszítettek. A legkésőbbi bepödrött végű karperecek Kovács László szerint 11. századi magyar pénzekkel is előfordulnak. A közölt anyagban én ilyeneket nem találtam. Ennek ellenére a szakonyi 28. sír karperece lehet 11. századi is. A 11. századra keltezett szőregi temető „A" sírja azonban még bizonyosan 10. századi. ${ }^{131}$ Kétségtelen, hogy voltak közösségek, ahol nagyon divatosnak tartották a pödrött végű karpereceket (Piliny, Ipolykiskeszi, Sárrétudvari, Kistokaj), máshol viszont elő sem fordulnak (Halimba, Majs, Kérpuszta stb.).

Arról is le kell mondani, hogy kizárólag női viseleti daraboknak tartsuk e karpereceket, mert a feleslegesen vitatott nagyhalász-zombor-hegyi példányon kívül biztosan férfi sírból kerültek elő Orosházán a Nagy Albert tanyánál és Sárrétudvariban a hízóföldi 160. és 252. sírban, valamint a kistokaji 68. sírban. ${ }^{132}$

\section{Csuklós karperecek}

A pántkarperecek harmadik típusát képezik. Szőke Bélánál nem szerepelnek, mert ő még nem ismerte azokat, bár a szarvasi és a bashalmi példányokat éppen azokban az években fedezték fel (Szarvas 1960 előtt, Bashalom 1958). Valójában csupán néhány darab került elő, de azoknak is két változata van: az egycsuklós és két félpántból álló kétcsuklós karperec. Az előbbit képviseli a Hajdúszoboszló-Árkos-halmi példány. Anyaga bronzlemez, amelyből egy 10 milliméter széles csíkot vágtak ki, felületét apró pontkörök ferde sorai díszítik (VI. t. 7.). A sírban mellette zárt bronz állatfejes karperec és egyszerű bronzhuzal karperecen kívül ezüst $\mathrm{S}$ végű hajkarika és kétrét hajtott bronzhuzalból csavart nyakperec is volt. ${ }^{133}$ Így kora egyértelműen a 11 . század első harmada. Párhuzamait ugyanebből az időből a Balkánról ismerem: ÉNy-Epirusból, Parapatamosból, az albán határ közeléből, ${ }^{134}$ Macedoniából Krstevi Koresmiaból, ${ }^{135}$ a bulgáriai Skalaból, ${ }^{136}$ Romániából Dinogetia/Garvanból. ${ }^{137}$ A legközelebbi párhuzama talán mégis a görögországi Nea Anchialosból való. Bár bronz pántja 1,8 centiméter széles, de a pánton váltakozóan poncolt apró pontkörök ferde sorai és fekvő U alakú egységek hármas csoportjai láthatók. ${ }^{138}$ Ezért lehetséges, hogy a hajdúszoboszlói csuklós pántkarperec idegen áru az Alföldön.

\footnotetext{
126 SZABÓ 1978-79, 64-66.

127 LANGÓ 2000, 42-44.

128 RÉVÉSz 2008, 232.

129 RÉvÉSz 2003, 435.

130 SzEDOv 1982, 233, 59. t.

131 Kovács 1989, 173, 9. jegyzet; BÁLINT 1991, 78-79.

132 Dienes 1965, 141; Nepper 2002, 329, 348; K. VéGH 1993, 59.

133 Nepper 2002, 69, 38. t.

134 Poulou-Papadimitriou - Tzavella - Ott 2012, 407-408, 17. kép

135 LANGÓ 2014, 327.

136 Jotov - Atanasov 1998, 116, 109. t. A település 25. számú veremházából 28 darab bizánci anonym follis keltezte a leletegyüttest a 11. század elejére.

137 Stefan - Barnea - Comsa - Comsa 1967, 291, fig. 172. 5.

138 BosselmanN-RUICKBIE 2011, 274.
} 
A batajnicai csuklós karperecről továbbra sem tudunk többet közöletlensége miatt. A földeáki karperecet viszont törölni kell a honfoglalás kori leletek közül. ${ }^{139} \mathrm{~A}$ legszebb egycsuklós karperec a csak rekonstrukcióban létező szarvasi pánt. Négy töredékét Kovalovszki Júlia fedezte fel a szarvasi múzeum leletei között, és teljesen meggyőzően egy egycsuklós karperecet szerkesztett ki belőlük. A mintegy három centiméter szélességú ezüstpánton keretelés nélkül öt medalion van elhelyezve, illetve egy megkezdett, de az első ötöd vagy hatodrész után egyszerűen levágták a kompozíciót. Az így kialakított pánthossz egy karperec számára elegendő. Az állatok valószínüleg griffek, de nagyon hasonlítanak a honfoglalás kori korongjaink állatalakjaihoz is. Az állatok egymással szemben, illetve háttal állnak, mellső lábukat lépésre emelik. A medalionok között összekötő tagok vannak, melyek alul és felül kitöltik a teret (VI. t. 10.). ${ }^{140} \mathrm{~A}$ medalionok körvonalai és az állatok rajza is poncokkal készült, a hátteret kissé visszakalapálta az ötvös és aztán tűzaranyozással fedte. Ez a technika teljes mértékben azonos a honfoglalás kori ötvösmunkák technikájával. A szarvasihoz legközelebb áll a tiszaeszlár-bashalmi kétcsuklós ezüst pántkarperec. A majdnem négy centiméter széles pánt mindkét felén 3-3 medalion van, de itt már keretbe foglalva. A keret, a medalionok kerete, a medalionokban ábrázolt madár és palmettacsokrok poncolással készültek. A félpántokon a pánt közepén levő palmetta két oldalán egy-egy gyöngytyúk szerű madár áll, testük a palmetta felé fordul, de fejük hátra néz. A medalionok kerete egy szakaszosan megcsavarodó szalagfonatot utánoz, de az ötvös a számára szokatlan feladatot nagyon leegyszerúsítve oldotta meg. Ennek ellenére a madáralakok megfogalmazása gyakorlott mesterre vall. Egykor a teljes felület aranyozva volt, ma már csak a csuklók mentén látható jól, és a poncbeütések alján (VI. t. 9.). ${ }^{141} \mathrm{~A}$ szarvasi és bashalmi karperecekkel kapcsolatban felmerült a bizánci eredet lehetősége, főleg amikor az első valódi párhuzamok felbukkantak. Elöbb a baltimorei Walters Art Galery arany karperece vált ismertté, majd a washingtoni Dumbarton Oaks szintén arany karperecét közölte M. C. Ross. Jóval később találkoztunk a Kanellopoulos-gyüjtemény arany karperecével, és végül egy kis múzeumra valót közölt együtt Antje Bosselmann-Ruickbie. ${ }^{142} \mathrm{~A}$ mi pántkarpereceink mintái aranyból, vagy ezüstből készültek. Többnyire öt-öt medalion van egy-egy félpánton, és a medalionokat niellóval kitöltött szőlőindás keretben helyezik el. A medalionok és az indák is lemezre készülnek, de domborítással. A medalionokban griffek, oroszlánok, madarak láthatók. A bashalmi karperec mintájához jó párhuzamot talált Bollók Ádám egy bizánci festett kéziraton. Véleménye szerint a bashalmi karperec állatalakjai idegenek a honfoglalás kori magyar ornamentika faunájában. Ezért szerinte ezek a karperecek lehetnek bizánci ékszerek magyar utánzatai. ${ }^{143}$ Mivel a bizánci ötvösök teljesen más technikát alkalmaztak karpereceiken, úgy véljük, e karperecek bizánci előképek nyomán készült magyar munkák. A második kétcsuklós karperec Ártándon került elő egy Péter (1038-1041) denárával keltezett sírból. ${ }^{144} \mathrm{Az}$ öntött bronzpántokon négy-négy páros félpalmetta van hátával a pánt széléhez támaszkodva, egy-egy pár pedig kissé összeszorítva hátával egymásnak támaszkodik. Mivel ezek a pántok öntéssel készültek, ezért általános megnevezésként a lemezkarperec helyett indokolt a pántkarperec megnevezést használni. A pántok felülete aranyozva volt, ennek ma már kevés nyoma van a mélyedésekben. Párhuzamát még nem sikerült megtalálni, de csuklós pántkarpereceink eredetét figyelembe véve, ez sem származhat máshonnan. A páros félpalmetták hasonló felhasználása egyébként egy bashalmi csaton és más vereteken is elöfordul. ${ }^{145}$

139 KIss 1985, 258, 259. A leletkataszter, amely ez esetben is Kiss Attila tárgylistájának alapja volt, a 321. tételszám alatt tartja nyilván a lelőhelyet. Megjelöli a tárgy őrzési helyét, a Nemzeti Múzeumot és megadja a leltári számát is: TM 78/1912. Irodalmi hivatkozásként Bálint Alajos múvét jelöli meg. „Csanád, Arad Torontál k.e.e. vármegyék régészeti katasztere. Makó, 1941.” Az adott helyen ezt találjuk: „A Nemzeti Múzeumban Kutasi Radisich iparmüvészeti múzeumigazgató közvetítésével egy bronzkarperecet őriznek, mely $1 \mathrm{~cm}$ széles lemezből s két végén csuklós taggal van összeerősítve." Megadja az előbb idézett leltári számot és a lelőhely tulajdonos Návay István birtokos nevét. A megadott leltári szám alatt azonban egy bronzkori tárgyat találtunk egészen más adatokkal. Ennek a birtokosnak a neve azonban már egyszer elém került, a nagykátai karperecek első említésekor. És valóban, az Archaeologiai Értesítő 1892-es évfolyamában a mondott helyen ez áll: „A népvándorlás végéről való jellemző karpereceket szereztünk két alföldi lelőhelyröl. Egy pár sírból való és hivatalos úton Nagykátáról jutott múzeumunkhoz...Ehhez némileg hasonlit egy harmadik karperec, melyet Radisics Jenő igazgató úr közbenjárásával Makóról Návay István földbirtokos ajándékozott." HAMPEL 1892, 379. Ezek után ellenőriztem a leltárkönyvet, s ott megtaláltam a Makóról való karperecet az 1892/78. számon. A leltárkönyvi tárgyleírás valóban egy pántkarperecre vonatkozik, amely azonban szarmata korinak látszik. Maga a karperec azonban jelenleg nem található meg a gyűjteményben. A leltárkönyvi leírás alapján e karperec leginkább egy endrődi szarmata karpereccel vethető össze: JuHÁsz 1978, 97-98.

140 KovalovszKI 1960, 173.

141 Dienes 1972, 48-50. kép.

142 Ross - Downey 1956-57, fig. 11; Ross 1965, 80, No. 108. 58. t.; Bosselmann-RuickBie 2011, 149-160. kép

143 ВоцLók 2015, 153, 176, 354, 412, 556.

144 MesterHÁzy 1965, 61-67; Mesterházy 2006, 223, 3. kép

145 То́тн 2014, 36, 38. t. 8.; ВоцLók 2015, 235, 42. kép 7-12. 


\section{A kézelö/mandzsetta díszítésére szolgáló fémszalagok}

Már érintettük azt a feltevést, hogy a karperecek valójában a ruhaujj leszorítására szolgáltak. Az ötlet mind a mai napig újra és újra felvetődik, többnyire a régóta ismert érvekkel alátámasztva. Néha előfordulnak újdonságnak látszó szempontok is. Az egyik ilyen, talán határozottan még meg sem fogalmazott szempont, hogy nem hihető a pánt karperec funkciója. A legújabbak közül való a Szeged-Kiskundorozsma-Hosszúhátról való 595. sír ezüst karperecpárja. A mindössze 6 milliméter széles ezüst pántok egyik oldala szabályosan eldolgozott, a másik azonban jól látható vágásnyomokkal az ideiglenességet sugallja, ${ }^{146}$ mintha mai gondolkodásunkkal úgy vélekednénk, a halottnak így is jó, a temetésre ez is megfelel. Ha a geszterédi sír aranypántjára gondolunk, ahol ugyanez a formai igénytelenség jelenik meg valódi nemesfém anyagban és valóban rangos temetkezés esetében, még feltűnőbbé válik a tartalom és forma ellentéte. A kiskundorozsmai 595-ös sír karperecei a sírfotón jól láthatóan a jobb alkar közepe táján és a bal csuklónál kerültek elő, ahová a halottat utolsó útjára felkészítő öltöztető asszonyok(?) helyezték azokat. Ez azt mutatja, hogy valójában karperec/pánt funkcióban látjuk ezeket az ékszereket. Az ideiglenességet sugalló tárgyi megjelenés tehát határozott és egyértelmű funkcióval párosul. Ezért nem hihető, hogy „.... a ruhaujj végén a kézelő díszítésében játszhattak szerepet,...mely nélkül azonban igen nehezen képzelhető el viseletük." Megoldásként úgy vélekedtek, hogy a pántok a sírban való helyzetük alapján „....a temetés során nagy valószínűséggel nem voltak a kézelöhöz rögzítve." ${ }^{147} \mathrm{~A}$ dilemma régóta kísért szakirodalmunkban, és érdekes módon éppen a legjobb régészeti megfigyelések hozzák felszínre. Az időben visszafelé legközelebb álló karosi ásatások adtak lehetőséget az addigi megfigyelések összefoglalására. Talán a karosi II/11. férfi sír pántjai voltak annak az ötletnek a kiváltói, amely szerint a karperecek és az annak látszó pántok közötti különbség a készítés technikájában van: míg az igazi karperecek öntöttek, addig az annak látszó darabokat szinte házilag „fusizták”, funkciójuk viszont azonos volt. ${ }^{148}$ A II/11-es sír leírásából és főleg sírrajzából kiderül, hogy a jobb csuklón egy 10 milliméter széles, és 9 centiméter hosszú, a két pántszél közelében egymással szemben egy-egy szegeccsel összefogott, mindkét végén töredékes félpánt került elő. A bal csuklótól legalább 15 centiméterrel távolabb, a bal combcsont felső végével egyvonalban volt egy teljesen ép félpánt, melynek mindkét végén egy-egy ütött lyuk van. ${ }^{149} \mathrm{Ez}$ arra mutat, hogy a funkciója nem azonos a valódi karperecekével. Arról nem esett szó, hogy ezek a pántok valójában körbeérik a csuklót és végeik egymás közelében is rögzíthetők.

Még érdekesebb Kürti Béla véleménye a kétségtelenül szép és pontosan dokumentált algyői sírok esetében. Bár a teljes dokumentáció még nem áll rendelkezésünkre, a lényeges adatok talán hozzáférhetőek. A 49. számú gazdag női sírban a feles(!) méretű sírrajzon jól látható a bepödrött végű pántok megtalálás kori helyzete az alkaron, a könyök alatt. Ugyanakkor ennek a sírnak a ruharekonstrukcióján az ingujj is kézelővel van összefogva. Kürti szerint ezek a karperecek nem is ékszerek, hanem az ingek díszei-tartozékai, amelyek a bőujjú inget fogták össze. ${ }^{150}$ Eltekintve attól, hogy a rajz szerint nem túl masszív karperecek nem alkalmasak finom kelme/selyeming összefogására sem, akkor mi szükség van a csuklón a kézelőre? Illetve, ha az ingnek van kézelője, akkor mi szükség van az alkaron egy fémpántra? Az 52. és 92. (férfi) váz csuklóján aranyozott ezüst pántokat találtak, végükön átlyukasztva: „Úgy gondoljuk, hogy e tárgyakat a temetés alkalmával varrhatták a ruhára." ${ }^{\prime 151}$ Bár ez utóbbi pántokat nem ismerjük, mégis úgy tűnik, ugyanolyan szerepük volt, mint a karosi II/11-es sír pántjainak - tehát nem karperecek.

Az időben visszafelé következő vélemény Dienes Istváné és László Gyuláé. Az orosházi Pusztai Ignácné tanya 2. sírjában, a bolygatatlan bal alkar alsó harmadánál került elő négy darab, néhány centiméteres ezüstszalag, szabálytalanul levágott végeiken egy-egy ütött lyukkal. A négy vékony szalagocska szélessége fél centiméter körüli, összhosszuk alig több 10 centiméternél. ${ }^{152}$ A rekonstrukciós rajzot, nyilván közös vélemény alapján, László Gyula rajzolta meg, ami nem hihető. A törékeny fémszalagok nyilván a ruhaujjra voltak felvarrva, de ezek nem húzhatták össze a bőujjú inget vagy kaftánt, ahogy ez a rekonstrukciós képen látható. László Gyula ezt a képet saját könyvében is felhasználta. ${ }^{153} \mathrm{~A}$ perzsa szikladomborművek és ezüsttálak ábrázolásaival világította meg a rekonstrukciós rajzot, „....amelyeken az ing buggyos ujját, nemkülönben a buggyos nadrágot ilyen pánt fogja össze." Amint látjuk, az orosházi rekonstrukció nem az orosházi pánttöredékek alapján készült. Ha az ingujjat valóban össze akarták fogni, akkor azt kézelővel oldották meg. A kézelőt lehetett díszíteni ezüst vagy aranylemezekkel, de azok nem fogtak össze semmit. Nagyon díszes kézelőt láthatunk az afganisztáni Tillia tepe

146 TÜRK - LÖRINCZY 2015, 20, 68-69, 41. kép

147 TÜRK - LÖRINCZY 2015, 69.

148 RÉvÉsz 1996b, 90.

149 Révész 1996b, 17, 17. t.

150 KüRTI 1983, 39. grafikai melléklet; KüRTI 1978-79, 327; KüRTI 1996, 151.

151 KÜRTI 1978-79, 327.

152 DienEs 1965, 146, 6. kép, rekonstrukció uo. 9. kép, a pántok fotója IX. t. 3.

153 LÁSZLó 1988, 64. 
fejedelmi sírjaiban ${ }^{154}$ annak bizonyítékaként, hogy nomád környezetben sem kell lobogós pásztor ingujjat feltételeznünk, amint azt Szabó Kálmán is romantikusan elgondolta. ${ }^{155} \mathrm{Ha}$ pedig ilyet is viseltek, akkor a karpereceket nem a ruhájuk ujjára szorították, hanem a puszta karjukra, melyek viselet közben nyilván a csuklójukra csúsztak le.

A ruhaujj végére, azaz a kézelöre/mandzsettára rávarrt pánt volt a dunaújvárosi 1,6 centiméter széles tǔzaranyozott bronzpánt, amelyen egy felvarrásra szolgáló ütött lyuk is volt. Mivel a pánt végei sérültek, ott nincs nyoma hasonló lyukaknak. ${ }^{156}$ A felvarrás módja ideiglenesnek látszik, de hát a célnak így is megfelelt. Még ennél is szélesebb (2 centiméter) volt a Csorna-Sülyhegyen, a halott nő alkarján talált ezüstpánt, amelynek közepe táján négyzetes rátét volt, melyet egy szegeccsel fogtak a pánthoz. Az egykori ásatási megfigyelés szerint a pánt végeit egy szerencsésen megmaradt fonal tartotta össze. Az egyetlen, sokat mondó leletről sajnos csak ennyi híradás maradt ránk. ${ }^{157}$ Viszonylag jó megfigyelést tett Patay Pál egy nógrádkövesdi sír feltárásakor. A bal alkarcsontok körül vékony ezüstlemezből kivágott karikát talált, rajta kis kerek lyukkal, amelyet a felvarrás céljából készültnek tartott. Hasonló ezüstkarika volt a jobb alkarcsontok körül is, de ez három félköríves darabból állt. A fényképes dokumentáció jól mutatja a feltáráskor tapasztalt helyzetüket, amit viszont az ásató nem tudott értelmezni, mert nem számolt egy mandzsettás ingujjal és az arra felvarrható fémszalagokkal. ${ }^{158}$

A dunaújvárosi kézelődísz párhuzamának tekintette Bóna István többek között a kenézlői 10. sír boka- és könyökízületei felett talált ezüstpántokat. Jósa úgy találta, hogy "mintha tölcsérnek harántszeletei lettek volna", azaz a pánt alsó és felső széle különböző hosszúságú volt, mindkét végén 2 milliméter széles lyukakkal. Ezek a szalagok is a halotti ruha tartozékai voltak, a pántvégeken levő lyukak a pántok „ideiglenes" felvarrására szolgáltak. ${ }^{159}$ Önkéntelenül is a híres thesszaloniki kincs „karpereceire”, illetve csuklópántjaira gondolunk (angolul wrist cuffs-nak írják). ${ }^{160}$ Néha olyan vékony ezüst vagy aranyszalagokat használtak fel erre a célra, hogy alig, vagy egyáltalán nem maradtak meg. Bálint Csanád említi, hogy Szabadkígyóson a 4. sírban csak az alkaron látható zöld patina nyoma jelezte egykori jelenlétüket. ${ }^{161}$

Ma már mintegy 20 hasonló szerepú pántot ismerünk (a fentebb tárgyaltakon kívül Ógyalla-Bagota 3. sír, Naszvad-Partok 2. sír, Naszvad-Rókalyuk 9. sír, Sárrétudvari-Poroshalom 1., 2., 3. sír, Köröstarján-Csordás domb 3. és 28. sír, Bátorkeszi/Vojnice-Papajtó 5. sír, Madaras-Árvai dűlő 6. sír, Berekböszörmény-Páldomb 3. sír, Bodrogszerdahely/Streda nad Bodrogom, Szeged-Öthalom 3. sír, Üröm). Egy részükre jellemző, hogy két félpántból vannak összeszegecselve (Köröstarján, Naszvad), a két szabadon álló pántvég át van lyukasztva a felvarrás céljából. Máskor a pántok hosszúsága egy teljes karperec pántjának megfelelő hosszúságú, vagy azt megközelítő (Sárrétudvari), de mint az orosházi négy rövidebb pántocska jelzi, a díszítést több szakaszból is összeállíthatták. Kiss Attila pántkarperec-listáján a valódi karperecek között szerepelnek, ezáltal el is tüntetve azokat a pántkarperecek két fő típusa között. A rossz vagy teljesen elmaradt régészeti megfigyelések és a 1920. századi viselet múltba való visszavetítése sokféle hibás elképzelésnek adott teret. Remélhetőleg a ruhaujjak végeinek/kézelőinek pántokkal való díszítése a jobb megfigyelésekre sarkallja a jövő feltáróit.

Befejezésül még egy lehetőséget vizsgálunk meg: lehetnek-e mandzsetták díszei azok a pántkarperecek, amelyeknek mindkét végén egy-egy lyuk van, lehetnek-e ezek a lyukak a felvarrás előfeltételei. Mint láttuk, az ibrányi 197a. sír imitált rátétes karperecén a végek széle előtt egy-egy ütött lyuk van, amelyeken az ásató összekötésre valló kopásnyomokat figyelt meg. De valószínüleg ugyanilyen kopásnyomok keletkeznek akkor is, ha nem a két lyukat fúzzük össze, hanem egyenként levarrjuk azokat az ingujjra. Ha gyors statisztikát végzünk az egy-egy lyukkal ellátott karperecek sírban való helyéről, a következő képet kapjuk. A megközelítőleg 30 lelőhelyről az esetek felében van pontos adatunk a karperec feltáráskor megfigyelt helyéröl (a másik fele szórvány, vagy megfigyelés nélküli). Hat esetben a csuklón vagy annak helyén került elő a mindkét végén átlyukasztott karperec (a jobb csuklón volt öt esetben: Csekej 401. sír, Karos II/45. sír, Sárrétudvari-Hízóföld 33. és 167. sír, Szolnok-Beke Pál halma III/5. sír, a bal csuklón találták Galánta-Papföld 6. sírjában). 12 esetben viszont az alkar valamelyik pontján, akár középtájon (Hencida 5. sír, Gyulavarsánd 1949/15. sír, lbrány 197a. sír, Karos III/6. sír, Marosgombás-Kis-Magura 10. sír, Szentes-Borbásföld 14. sír, Tiszapüspöki, bizonytalanul ide sorolva Szentes-Szentlászló 74. és 95. sír), akár feljebb, a könyök közelében (Tiszavasvári-Aranykerti tábla 13. sír, Kál-Legelő 10. sír), akár lejjebb (Tiszanána-Cseh tanya 2. sír). Ha valamennyi esetben a csukló felett találták volna meg a pántokat, meggyőző lenne számunkra a kézelőn való viselet szokása. Valami ilyesmit képzelt el László Gyula is azzal a különbséggel, hogy szerinte a pántok nem voltak rávarrva az ingujjra, csak a pánt vé-

\footnotetext{
154 SzARIANIDI 1983, 19. színes kép

155 SZABÓ 1938.

156 BónA 1971, 170.

157 Bella 1895, 253; Hampel 1905, II. 524, III. 367. t. 1.; SzÖKe 1954, 131.

158 Patay 1957, 58-59.

159 Jósa 1914, 313; Bóna 1971, 172.

160 Katalógus 1997, 243-244, No. 165.; Bosselmann-Ruickbie 2011, 274-279.

161 Bálnt 1971, 56; Mesterházy 2013, 207.
} 
gén levő lyukakon keresztülhúzott szalag szorította rá a csuklóra. Ezt nevezte perzsás viseletformának. ${ }^{162}$ Más kérdés, hogy a kézelő a temetéskor mennyire csúszhatott fel a halott karján. A levarrásra utalhat viszont egy Szeged-Öthalomról való (V. homokbánya 150. sír) pödrött végű keskeny ezüstpánt. Egyik végén a bepödrés előtt van egy kis, valószínűleg levarrásra szolgáló lyuk, pedig a jobb alkar felső harmadánál került elő. ${ }^{163}$ További bizonytalansági tényező, hogy nemcsak női sírban találjuk meg a lyukas végű pántkarpereceket, hanem férfi sírokban is (Arad-Csálya, bár az nem hiteles feltárásból származik). Nagy kár, hogy nincs olyan megfigyelésünk sem, amely a pántkarperec belső oldalához tapadó/hozzá oxidálódott textilmaradványt említene meg. Néhány esetben ugyan szó esik a pánton fémrozsdával megőrződött textilmaradványokról, de nem tartották fontosnak a pontos leírást (Sárrétudvari-Hízóföld 167. sír), megelégedtek a karperec külső felületére tapadt durva textil fényképes rögzítésével. A pilinyi Sirmányhegy 73. sírjában is vászonmaradványok oxidálódtak a pödrött végü karperechez, de ennél többet nem tudunk meg a leírásból. ${ }^{164}$ Talán a balkáni néprajzi anyagban sikeresen kereshetnénk párhuzamokat. A hertelendyfalvai leletben, amely sajnos szórványnak tekinthető, a mi Árpád-korunkra utaló környezetben van egy pántkarperec (III. t. 6.), amelynek a végei át vannak lyukasztva. ${ }^{165}$ A mirijevói középkori temetőből a 14. század végéről is találunk olyan pántkarperecet, illetve annak leszármazottját, mint a nádudvar-töröklaponyagi vagy a hozzá hasonló pontkörös díszítésű példányok. ${ }^{166}$ Mivel ebben a kérdésben nem sokkal jutottunk közelebb a megoldáshoz, valószínűleg több figyelmet kell fordítani a történeti-néprajzi párhuzamok kutatására.

\section{Adattár ${ }^{167}$}

\section{Ki- és lekerekedő végü karperecek}

Arad-Csálya (Ro.). Az ún. X. sírból két kikerekedő végű bronz pántkarperec került elő. Az egyik végein ütött lyuk látható. A férfi sírban szablya volt, palmettás mintájú markolatgombbal. Mivel a szórvány leletek között egy másik karperec töredéke is van, a leletek egybetartozása nem feltétlen hitelü. ${ }^{168}$

Bajót (Komárom-Esztergom m.). Aranyozott bronz lemezkarperec ráforrasztott ezüstdísszel és kék üvegbetéttel. Mára elveszett. ${ }^{169}$

Bánkeszi 23. sír (ma: Bánov, SI.). Keskeny, 8 milliméter széles, lekerekített bronzpánt, mindkét végen két-két ütött lyukkal (III. t. 1.). A egyik lyukpár közvetlenül a pántszéleken van, a másik pár majdnem 1 centiméterrel beljebb. Anton Točik megjegyzi, hogy az „Enden, die Niete tragen”. ${ }^{170}$

Békés-Hidashát (Békés m.). Végein kiszélesedő és kikerekedő ezüstpánt. ${ }^{171}$

Békéscsaba-Erzsébethely (Békés m.). Bronzpánt, alig kiszélesedő vége levél alakúan megnyúlik és keskeny mandzsettával csatlakozik a pánthoz. ${ }^{172}$

Berekböszörmény-Pál-dombja 2. sír (Hajdú-Bihar m.). Bronz pánt, egyik végén rovátkos szegélyű bronz, csepp alakú rátét, közepén kerek lyukban kék üvegpaszta berakással. A másik pántvég hiányos. A 6. sírban kikerekedő végü, ezüst pántkarperec volt, csorba végekkel. Közöletlen.

Berettyóújfalu, B. Nagy Sándor földje (Hajdú-Bihar m.). Ezüst pántkarperecek, kiszélesedő és kikerekedő végekkel, az egyiken a kikerekedő részen palmetta díszítéssel. Az együtt talált övveretek alapján férfi sír volt. ${ }^{173}$

Biharkeresztes, Bethlen G. út 1. sír (Hajdú-Bihar m.). Ezüst pántkarperec kiszélesedő és lekerekített végekkel, melyeken egy-egy ütött lyuk van (III. t. 2.). A sírban szvasztika díszes hajfonatkorongok mellett pödrött végü bronz pántkarperec is volt. Női sír. ${ }^{174}$

Bodrogvécs (Več, ma Szomotor része, SI.). Két darab kikerekedő végű ezüst pántkarperec. ${ }^{175}$

Boldog-Téglaházi part (Heves m.). Talán kikerekedő végű pántkarperec, bronz, első leírása pontatlan, és elveszett. ${ }^{176}$

162 LÁSZLÓ 1988, 65.

163 TÜRK - LöRINCZY 2015, 38, 69, 104. kép

164 Nepper 2002, 332; HAMPEL 1907, 183-184.

165 Bálint 1991, 103, Abb. 27.; Stanojev 1989, 39-42.

166 BAJALOVIĆ-BIRTAŠEVIĆ 1960, XII. t.

167 Rövidítések: Hrv. = Horvátország, Ro. = Románia, SI. = Szlovákia, Srb. = Szerbia, U. = Ukrajna, m. = megye

168 GálL 2013, 41, 4. t. 1-2; KISS 1985, 257.

169 BaLogh 1938, 583; MRt 1979, 52; KISS 1985, 258.

170 TočIK 1968, 14, 5. t. 8., KISs 1985, 258.

171 MRT 1998, 74, 123. t. 32.

172 RÉvÉsz 1997, 169, 2. kép 2-3.

173 SÖREGI 1948, 8; KATALÓGUS 1996, 215; KISS 1985, 258.

174 NepPer 2002, 28.

175 Dókus 1900, 39-61, 6. ábra 1-2; HAMPEL 1905, II. 264-265; KISS 1985, 262.

176 KISS 1985, 258; RÉVÉSZ 2008, 71. 
Borosbenedek (Ro.). Bronz pántkarperec, egykor a nagyenyedi múzeum gyűjteményében volt, mára azonosíthatatlanná vált. ${ }^{177}$

Budapest XX. Pesterzsébet, Külső Török Flóris u. 121. (illetve más néven Soroksár, Szent László u. 121., Pest m.). 9 milliméter széles ezüstpánt, a pánt szélességével azonos szélességű kikerekedő végei kis nyakkal kapcsolódnak a pánthoz (III. t. 3.)..$^{178}$

Csákberény-Pusztaorond (Fejér m.). Két darab ezüst pántkarperec, az egyik kiszélesedő és kikerekedő, de mindkét vég függőlegesen letörött, a másik pánt egyenletes szélességű és lekerekített. ${ }^{179}$

Csekej (ma: Čakajovce, SI.). 579. sír: Egyenletes szélességű, lekerekített végú bronzpánt, mellette hajfonatkorongok, csüngős veretek, gömbsorcsüngős fülbevaló, női sír. 401. sír (III. t. 4.): kissé kiszélesedő, de egyenesen levágott bronzpánt, rajta kettős vonalú X-ek sora. Mindkét vége átlyukasztott. A párja keskeny bronz pántkarperec volt, melynek végei hiányoztak, a pánton rezgő vonalú rombuszokban pontkörös beütés látható, feltehetően pödrött végű karperec volt. ${ }^{180}$

Csólyospálos (Bács-Kiskun m., egykor Kiskunfélegyháza, Csólyos-puszta). Ezüst lemez, talán pántkarperec töredékei. ${ }^{81}$

Csongrád (Csongrád m.). Ezüst lemezkarperec, egyenletes szélességú pántja félkörösen lekerekített. ${ }^{182}$

Csongrád-Vendel-halom 26. férfi sír (Csongrád m.). 4-5 milliméter széles ezüst pántkarperec három töredékben a jobb alkarról, eredetileg lekerekített lehetett. ${ }^{183}$ Egyéb melléklet: négy nyílcsúcs, csontlemezek.

Csorva-Ruzsajárás (Csongrád m.). Két darab kikerekedő végű bronz lemezkarperec. ${ }^{184}$

Eger-Répástetö 1. sír (Heves m.). Szablyás férfi temetkezésében két keskeny ezüst pántkarperec, mindkettő lekerekített végü. Az egyik karperecen szakaszosan karcolt sávok díszítik a pántot. ${ }^{185}$

Eger-Szépasszonyvölgy (Heves $\mathrm{m}$.). A temető régészeti anyaga, amennyiben nem teljesen egyedi tárgy, öszszekeveredett. A leltár szerint négy sírban is voltak pántkarperecek. Összesen hét kikerekedő végú pántról lehet tudni, ezek közül egy ezüst. A táblarajzokon lehet látni egy oválisan kikerekedő, egy tárcsa-szerűen kikerekedő és végén átlyukasztott példányt, és egy töredezett végú darabot. ${ }^{186}$

Egyek (Hajdú-Bihar m.) Két darab ezüst pántkarperec, kikerekedő végekkel, az egyik díszítetlen, de gerincelt véggel, a másik rátétdíszes (III. t. 8.). ${ }^{187}$

Eperjes-Kiskirályság, Sáfrány János tanya (azonos a Takács tábla lelőhellyel, Csongrád m.). Kikerekedő végủ ezüst pántkarperec. ${ }^{188}$

Eperjeske 3. sír (Szabolcs-Szatmár-Bereg m.). Két darab inkább lekerekedő végű ezüst pántkarperec. ${ }^{189}$

Esztergom (Komárom-Esztergom m.). Hampel szerint ezüst pántkarperec kikerekedő végekkel. ${ }^{190}$

Gádoros 2. sír (Békés m.). Fettich N. szúkszavúan egy-egy „vékony bádogból” készült pántkarperecet említ, az élére állított tárgy fotója értékelhetetlen. A 2. világháborúban megsemmisült. ${ }^{191}$

Galánta-Papföld 6. sír (SI.). Bronz pánt enyhén kiszélesedő és félkörösen lekerekedő, átlyukasztott végekkel. Ugyanott szórvány ezüst pántkarperec kiszélesedő és kettős karéjjal záruló végekkel (III. t. 5.). ${ }^{192}$

"Galgóc" (SI.). Ezüst pántkarperec, egyik vége hiányzik, másik vége tárcsa-szerúen kikerekedik, és átlyukasztott (II. t. 2.). A galgóci sírlelethez keveredett, de valódi honfoglalás kori karperec. ${ }^{193}$

Gáva-Vásártér 28. sír (Szabolcs-Szatmár-Bereg m.). Női sírból való, kiszélesedő, félkörösen kikerekedő, a pántvégen gerincelt karperec. Köznépi temető gazdag sírja gömbsorcsüngős fülbevalóval, rombusz alakú ingnyakveretekkel, tömör bronzgombokkal (II. t. 3.). ${ }^{194}$

\footnotetext{
177 KISS 1985, 258; GálL 2013, 64.

178 Kiss 1985, 258; BenCZE - SzIGETI 2015, 98, 9. kép 2.

179 Fehér - ÉrY - Kralovánszky 1962, no. 158; KISS 1985, 258.

180 ReiHOLCOVÁ 1995, 63, 92. t. 23, és 43, 64. t. 10.

181 KADA 1912, 323; SZÖKE 1962, 23; KISS 1985, 258.

182 FehÉr - Éry - Kralovánszky 1962, no. 195.; KISS 1985, 258.

183 PÁrducz - TARY 1939, 191, 1. t. 35.; KIss 1985, 258.

184 Fehér - Éry - Kralovánszky 1962, no. 201.; Kiss 1985, 259; Bálint 1991, 218, no. 52.

187 Dienes 1972, 84, 51. kép; Katalógus 1996, 217-218; Kiss 1985, 259.

188 BÁLINT 1991, 52; KISS 1985, 259.

189 Kıss 1920-23, 47, 10. kép; Kıss 1985, 259.

190 Hampel 1907, 114-115, 12. t.; KIss 1985, 259; MRT 1979, 228, 44. t. 18-19.

191 FEтTICH 1937, 103, 91. t.; KISS 1985, 259.

192 Točı 1992, 142, 90. kép 14, 149, 93. kép 17; Kıss 1985, 259.

193 FетTICH 1937, 76-77; Toс̌IK 1968, 26; KISS 1985, 260.

194 IsTVÁNOVITS 2003, 60, 311, 44.t.
}

185 SzABó 1964, 115-117, 8-9. ábra; Révész 2008, 104. A rajzos táblán hiányzik a karperec karcolt díszítése. KIss 1985, 259.

186 Bartalos 1899, 129-130, 353-360; Hampel 1900, 572-580; Kiss 1985, 259; Révész 2008, 119, 37-38. t. 
Gégény-Vasúti őrház (Szabolcs-Szatmár-Bereg m.). Állítólag lovas sírból, keskeny kikerekedő végű bronz lemezkarperec, mellette nyílcsúcsok és lószerszámok is voltak. A pántvég hasonlít a „galgóci” karperecéhez. ${ }^{195}$

Génye 1. sír (ma: Geňa, SI.). Széles ezüstpánt valódi kikerekedő végekkel, párja bronz huzalkarperec, hegyesedő végű gyűrűsen ízelt végekkel, női sír. ${ }^{196}$

Geszteréd (Szabolcs-Szatmár-Bereg m.). Arany pántkarperec, lemezből kivágva, mindkét vég egyenesen levágott, de az egyik oválisan kikerekedő pántvég utánzata szögletes oldalakkal, rajta ütött lyukkal (II. t. 4.). ${ }^{197}$

Gödöllő (Pest m.). Kaffka László birtokán előkerült férfi sír, leletei közt kikerekedő végű ezüst pántkarperec, hat nyílcsúcs, lószerszám, tegezvasalások, szablya. A leletek a föld tulajdonosánál maradtak, és a világháborúban elásott rejtekhelyen várják ismételt megtalálásukat. ${ }^{198}$

Gyömöre (Győr-Sopron-Moson m.). Friedrich Károly kertjében talált rozettás lószerszámos sírból 6 milliméter szélességű, keskeny ezüst pánt egyenesre levágott végekkel és lekerekített sarkokkal. Jelenleg nem található. ${ }^{199}$

Győr-Újszállások (Győr-Sopron-Moson m.). Kiszélesedő és félkörösen lekerekedő végű aranyozott ezüstpánt, rajta az egész pánton végighúzódó két vízszintes hornyolat (III. t. 7.).200

Gyula-Téglagyár, 10., 37., 45. sír (Békés m.). Pántkarperecek élükre állított fényképpel, minden leírás nélkül. Mivel a lelőhely hiányzik a leletkataszterből, így Kiss Attilánál sem szerepel. ${ }^{201}$

Gyulafehérvár 41. sír (ma: Alba lulia, Ro.). Cserni Béla ásatása 1906-1908-ból. Bronz pántkarperec, mindkét végén töredékes. Valószínűleg a mentőállomás melletti temetőről van szó, Gáll Erwin nem foglalkozik vele. ${ }^{202}$

Gyulavarsánd-Laposhalom (ma: Varsand, Ro). Domokos J. ásatásából szórvány ezüst pántkarperec kiszélesedő és kikerekedő végein egy-egy ütött lyukkal (II. t. 7.). ${ }^{203}$ Kammer ásatásából szórvány ezüst pántkarperec kiszélesedő és lekerekített végekkel, amelyeken préselt fekvő V alakú borda fog közre csepp alakú díszítést, ezzel egy nagyobb csepp alakú rátétet utánozva. ${ }^{204}$ Kammer ásatásából két pár további pántkarperec, az egyik szélesebb pánt, Medgyesi szerint bronz, Gáll szerint, valószínúleg hibásan, ezüstnek írva, és egy másik keskeny pánt kiszélesedő végekkel, anyaga nincs említve. ${ }^{205}$ D. Popescu ásatásából, 15/1949. sírban keskeny bronzpántok kikerekedő és átlyukasztott végekkel. ${ }^{206}$

Hajdúböszörmény, Vidi föld, Erdős tanya (Hajdú-Bihar m.). Ezüst pántkarperec kiszélesedő és kikerekedő végekkel, férfi lovas sírból. ${ }^{207}$

Hajdúböszörmény (Hajdú-Bihar m.). Szórvány sírleletben sárgaréz(?) pántkarperec ovális pántvéggel, amely vésett mandzsettával van elválasztva a pánttól. A leletben övveretek és lószerszám mellett két gömbsorcsüngős fülbevaló is van. ${ }^{208}$

Hencida (Hajdú-Bihar m.). 1. sír: bronz pánt, kiszélesedő és kikerekedő pántvéggel a leány sírban a bal csuklóról. 5. sír: rozettás lószerszámos női sírban két kiszélesedő és kikerekedő végű karperec, mindegyik ezüstből. A bal karon levő pánt végein ütött lyuk, ez a kevésbé kiszélesedő végű, a másik karperec pántvége erőteljesebben kikerekedő és gyenge gerinc húzódik rajta végig. Fettich sírrajza szerint a jobb karon levő karperec a csukló felett volt, a bal kézen levő az alkar közepe táján. 10. sír: férfi váza, bal csuklóján ezüst pántkarperec kikerekedő végekkel, amelyek a pánt középvonalában mintegy másfél centiméter hosszan alig láthatóan gerinceltek, és vékonyra kalapáltak. ${ }^{209}$

Hertelendyfalva (ma: Vojlovica, Srb.). 11-12. századi sírleletből bronz pántkarperec kiszélesedő, egyenesen levágott és lekerekített sarkú végekkel, melyeken egy-egy ütött lyuk látható. A pánt poncolt szegéllyel és középvonallal, közben kis körökkel díszített (III. t. 6.).210

Hetény 60. sír (ma: Chotin, SI.). A váz jobb kezén bronz lemezkarperec, elnyúltan kiszélesedő és kikerekedő pánt. Kiss Attila a 83. sírnál is karperecet jelez, de sem az ásató, sem Anton Točik nem szól róla. ${ }^{211}$

195 Jósa 1914, 179, VI. kép; KısS 1985, 259; IstVÁNovits 2003, 67, 311, 51. t. 5.

196 NevizÁNSZKY 2013, 185, l. t. 9.

197 Kiss 1938, 16; Katalógus 1996, 77; AlmÁssy - IstVÁNOVITS - KuRucz 1997, 112, 99. kép.

198 SUPKA 1911, 180-181, 9. ábra; KISs 1985, 259.

199 BörzsönYı 1912, 217, b. kép; SzÖKE 1954, 128-129; Kıss 1985, 259; HoRvÁTH 2014, 34, 2. t. 7.

200 FETTICH 1943, 48, 48. t. 12-13.; HORVÁTH 2014, 56, 14. t.; KISS 1985, 259.

201 BAKAY 1978, 62. t. 16., 61. t. 13., 65. t. 6, 7-8.

202 HOREDT 1958, 62, Abb. 13.4.; KISS 1985, 257.

203 MedGYESI 1995, 101, 18. t.; GÁLL 2013, 94. t.

204 MedGYESI 1995, 99, 5. t. 1.; GÁlL 2013, 209, 88. t.

205 MedGyesI 1995, 99, 8. és 9. t.; GÁlL 2013, 209, 89. és 90. t.

206 MedGyesı 1995, 102, 23. t.; GÁlL 2013, 215, 97-98. t.; Kıss 1985, 263.

207 SÖREGI - ZoltAl 1927, 16-19; KovÁCs 1984, 25, 5. ábra; KISS 1985, 259.

208 HAMPEL 1907, 117, 15. t.; KISS 1985, 259.

209 Fеттісн 1937, 96-97, 80. t. 6., a sírrajz: 87. t. 2., 85. t. 42. és 41., 88. t. 29.; Kiss 1985, 259.

210 Bálint 1991, 103, 27. kép; Stanojev 1989, 42.

211 DUŠEK 1955, 251, no. 62. kép; TočIK 1968, 28, 18. t. 24.; Kıss 1985, 258. 
Hódegyháza 5. sír (ma: Jázova, Srb.). Köznépi temető gazdagabban ékszerezett sírral, női váz, bronz pántkarpereccel, kiszélesedő pánt kis ívben lekerekedő végekkel, párja bronz huzalkarperec középen és huzalvégeken többszörös gyűrűs díszítéssel, kéttagú csüngők, kerek préselt rozetták stb. Bálintnál 6. számú sírként említve. ${ }^{212}$

Hódmezővásárhely-Kopáncs 10. sír (Csongrád m.). Gyermek sír, bal csuklóján széles, ezüst pántkarperec három töredéke, az egyik töredéken ütött lyuk. ${ }^{213}$ Mivel a leletkataszter címszavában nincs felsorolva a karperec, Kiss Attila sem említi.

Ibrány-Esbó-halom 197a. sír (Szabolcs-Szatmár-Bereg m.). Köznépi temető, melléklettel gazdagon ellátott sírja, az ezüst pántkarperec a jobb alkaron volt, a pánt végein mandula alakú, hátulról domborított rátétimitációval és egy-egy lyukkal (III. t. 9.). ${ }^{214}$ A 206. sírban bronz pántkarperec, egymást fedő, kiszélesedő és megközelítőleg derékszögben záródó oldalakkal. Női sír, hajfonatkorongokkal. ${ }^{215}$

Ipolykiskeszi 224. sír (ma: Male Kosihy, SI.). Mindkét végén sérült bronzpánt, enyhén kikerekedő véggel. ${ }^{216}$

Jánoshalma-Kisráta (Bács-Kiskun m.). Az 1. sírban férfi nyugodott, kikerekedő végü ezüst pántkarpereccel, a mellette levő „A" sírban bizánci solidus fele volt. 217

Kál-Legelő 10. sír (Heves m.). 22-26 év körüli nő jobb alkarján a könyök alatt kb. 12 centiméterre keskeny bronz pántkarperec, egyenletes szélességű, félkörben lekerekedő véggel, rajta ütött lyuk. A másik pántvég sérült. 218

Karos I. temető 12. sír (Borsod-Abaúj-Zemplén m.). Két darab "lapos karperec" kikerekedő végü, de adataik bizonytalanok, elvesztek. ${ }^{219}$

Karos II. temetö 3., 12., 29., 45., 47., 53., 54., 56., 61., 66. sír (Borsod-Abaúj-Zemplén m.). 3. sír: ezüst pántkarperec ötszögű pántvéggel, gyermeksírból. ${ }^{220} 12$. sír: bronz pántkarperec, ovális alapforma szögletesen kivágott pántvégződéssel. ${ }^{221} 29$. sír: ezüst pántkarperec, egyik végén átlyukasztott, másik pántvégen nincs lyuk. ${ }^{222} 45$. sír: a jobb csukló helyén, mindkét végén átlyukasztott kikerekedő végú ezüstpánt. ${ }^{223} 47$. sír: ezüst karpántok, szabálytalan pántszélekkel, egyenletes pántszélesség mellett lekerekített pántvégek.224 53. sír: kikerekedő végú pánt, formája teljesen azonos a karperecekével, de a jobb bokánál került elő. ${ }^{225} 54$. sír: ezüst pántkarperec vékony lemezből, egyik vége egyenesen levágott, másik vége félkörben lekerekített. ${ }^{226} 56$. sír: a jobb alkaron ezüst pántkarperec kikerekedő végekkel.227 61 . sír: kikerekedő végű ezüstpánt , mindkét végen kétszer átlyukasztott, férfi sírból. ${ }^{228} 66$. sír: bronz pántkarperec, kikerekedő végekkel, másodlagos helyről. ${ }^{229}$

Karos III. temető 6., 9., 13. sír (Borsod-Abaúj-Zemplén m.). 6. sír: két töredékes ezüst lemezkarperec, kiszélesedő, de szabálytalan végekkel, az egyik pántvégen két ütött lyuk nyomával. 2309 . sír: két darab kikerekedő végü, aranyozott ezüst pántkarperec. ${ }^{231} 13$. sír: mindkét karon ezüstlemez pántkarperecek, keskeny, szabálytalan szélü és töredezett végű pántvégekkel, férfi sírból.232

Kecel-Lehoczky János tanyája (Bács-Kiskun m.). Egyenletes szélességú, keskeny ezüstpánt karperec, lekerekedő és egymásra érő végekkel. ${ }^{233}$

212 Bálint 1991, 229; Stanojev 1989, 48, no. 234.; Kiss 1985, 260.

213 PÁrducz 1943, 185, 62. t. 22-24; FeHÉR - ÉRY - KRALOvÁnSZKY 1962, 397. tétel

214 IsTVÁNOVITS 2003, 99, 313.

215 IsTVÁNOVITS 2003, 103, 311, 102. t.

216 HANULIAK $1994,127,46 . t$.

217 Bálint 1991, no. 108; LANGó 2012, 49-50, fig. 1; KISS 1985, 260.

218 Révész 2008, 201, 52. t. 8.

219 RévÉsz 1996b, 14.

220 RÉvÉsz 1996b, 16, 9. t. 6.

221 Révész 1996b, 18, 26. t. 11.

222 Révész 1996b, 39. t. 4.

223 Révész 1996b, 24, 59. t.

224 Révész 1996b, 24, 62. t.

225 Révész 1996b, 28, 91. t.

226 Révész 1996b, 29, 93. t. 3.

227 Révész 1996b, 29, 94. t.

228 RÉvÉsz 1996b, 30, 101. t.

229 RÉvÉsz 1996b, 31, 105. t.

230 RÉvÉSz 1996b, 34, 115. t.

231 RÉvÉsz 1996b, 35, 118. t.

232 RÉvÉSz 1996b, 37, 130. t.

233 WinkLeR 1912, 322-323; KISS 1985, 260. 
Kecskemét-Lakihegy A sír (Bács-Kiskun m.). „....erősebb ezüstlemezből kivágott, s végein átlyukasztott pánt töredékei, valószínüleg ruhaujj-szorító karperecek voltak."234

Kenézlö-Fazekaszug I. temető 7., 16. sír (Szabolcs-Szatmár-Bereg m.). 7. sír: enyhén kiszélesedő bronzpánt, kis ívben lekerekedő végekkel. 16. sír: bronz pánt kiszélesedő és kikerekedő végekkel. ${ }^{235}$

Kenézlö-Fazekaszug II. temető (Szabolcs-Szatmár-Bereg m.). 26. sír: két darab keskeny bronzpánt félkörben lekerekedő végekkel. 34. sír: két darab bronzpánt karperec, mindkét pántvég levágott sarkai lekerekednek, a második karperec azonban pödrött végűnek látszik, poncolt háromszögsorral díszítve. 41. sír: bronz pántkarperec a jobb alkaron, a pánt a végei felé több milliméterrel kiszélesedik, egyenesen levágott és a sarkak lekerekítettek. 44. sír: bronz pántkarperecek, az egyiknek a pántvége kiszélesedő és egyenesen levágott, csak a szögletet kerekítették le, a másik egyenletesen széles, keskeny pánt félkörösen lekerekített pántvéggel. 47. sír: ezüst pántkarperec pár, mindegyik kiszélesedő, de különböző mértékben. A keskenyebb darab pántvége kevésbé is kerekedik le, egyenesebb, mint a szélesebb pánt vége. 49. sír: két darab ezüst pántkarperec, a pántvégek kiszélesednek 2-3 milliméterrel, egyenesen levágottak, a sarkaikat lekerekítették. 50. sír: ezüst pántkarperec, a pántvég kevéssé kiszélesedik és kikerekedik. A karperecek adatai Fettichnél hiányoznak, ha fényképes ábrázolásuk van, az az élükre fektetett pántoknál nem jelent többletet. ${ }^{236}$

Kiskunfélegyháza-Ferencszállás (Bács-Kiskun m.). Karperecpár, az egyik egyszerű bronzpánt, csak töredékei maradtak meg, a másik azonban ezüstből készült, kikerekedő végű, a teljes pánton poncolt palmettainda volt. Csak László Gyula rajza alapján ismerjük, a második világháborúban elpusztult (I. t. 4.). ${ }^{237}$

Kistokaj-Gerenda (Borsod-Abaúj-Zemplén m.). Szórvány pántkarperecek, az egyik ezüstpánt kikerekedő végü, rajta csepp alakú rátét üvegpaszta betéttel (III. t. 10.), a másik bronzpánt kikerekedő, részben egymásra érő végekkel. ${ }^{238}$

Kiszombor, F-temető (Csongrád m.). Avar temetőrészletben nyolc magyar temetkezés, az egyik sírban kiszélesedő végü ezüst pántkarperec volt a leletkataszter szerint. ${ }^{239}$

Koppányszántó-Belterület (egykor Tolnaszántó néven is, Tolna m.). Kammerer Ernő gyűjteményében sárgaréz lemezből készült karperec. ${ }^{240}$ Végei kissé kiszélesedők, egyenesen levágottak, és egy keskeny pánttal az alsó pántszél össze van kötve.

Koroncó-Bábota II. sír (Győr-Sopron-Moson m.). Rozettás lószerszámos női temetkezésben bronz pántkarperec, kiszélesedő és lekerekített pántvéggel. A karperec jellegét csak Horváth Ciprián leírásából ismerjük, aki viszont átvette László Gyula fényképét a karperecről is. Az pedig a karperec végeinek megítélésében semmitmondó. Állítólag ezüstözött, de valószínűbb az ónozás. ${ }^{241}$

Koroncó-Dózsa Gy. út (Győr-Sopron-Moson m.). Rozettás lószerszámos női sír pántkarperece ezüstből, oválisan kikerekedő végekkel. ${ }^{242}$

Koroncó-Rácdomb (Győr-Sopron-Moson m.). Rozettás lószerszámos női sír karperece, egyenesre levágott végű keskeny pánt, Szőke Béla szerint aranyozott ezüst, Horváth Ciprián szerint aranyozott bronz. ${ }^{243}$

Körösszegapáti-Pállapály (Hajdú-Bihar m.). Szórvány bronz pántkarperec, a pántvégek kiszélesednek, kettős karéjosak, a pántvég középvonalában egy rövid szakaszon gyengén gerincelt. ${ }^{244}$

Madaras-Árvai-dülő 4. sír (Bács-Kiskun m.). Ezüst pánt kiszélesedő, egyenesen levágott végekkel, de a levágáskor képződő sarkokat lekerekítették. Mindkét végen három-három aklaszeggel felerősített nagy csepp alakú rovátkolt szélű rátét van, amelynek közepén eredetileg üvegpaszta berakás ült. Az egyik rátét már a temetéskor hiányzott, csak a három szegecslyuk jelzi a helyét. A meglevő rátétből az üvegpaszta betét esett ki az idők folyamán, érdekes módon pont alatta van az egyik szegecslyuk. Ezek szerint a rátét felerősítésére két szegecs szolgált, a harmadiknak más szerepe volt. A berakás alatt levő szegecslyuk valamivel kisebb a másik kettőnél (l. t. 2.). ${ }^{245}$

Magyarpécska (ma: Pecica, Ro.). Szórvány bronzkarperec, kiszélesedő és kikerekedő végekkel. ${ }^{246}$

234 SZABÓ 1955, 123; KISS 1985, 260.

235 Jósa 1914, 309-310, 324; Kiss 1985, 260.

236 FEтTICH 1931, 80, a 26. sír karperecéről nincs fénykép, 88, 65. kép, 92, 71. kép, 93, a 44. sír karperecének nincs fényképe, 96, 84. kép, 98,

83. kép, 100, 86. kép; Kıss 1985, 260.

237 KadA 1912, 326; LÁszló 1943, 1. kép; LÁszló é.n. 69, 38. kép; Kiss 1985, 260.

238 K. VÉGH 1993, 23. kép 11-12.

239 FehÉR - ÉRY - KralovÁnSZKY 1962, 576. tétel; KISS 1985, 260.

240 WOSINSKY 1896, 1042; ÓDOR 1999, 156; KISS 1985, 260.

241 LÁsZló 1943a, 7; SZÖKE 1954, 125; HORVÁTH 2014, 82, 26. t. 117.; KISS 1985, 260.

242 SZÖKE 1954, 126-127, 3. kép; HoRvÁTH 2014, 86, 32. t.; Kıss 1985, 260.

243 SZÖKE 1954, 125; HORVÁTH 2014, 91, 37. t.

244 NePper 2002, 126, 124. t.

245 KÖHEGYI 1980, 218, 15. kép 4.

246 BÁLINT 1991, no. 75.; GÁLL 2013, 154; KISS 1985, 261. 
Mándok-Tetenke (Szabolcs-Szatmár-Bereg m.). Rozettás lószerszámos női sírban kiszélesedő, egyenesen levágott és a sarkain lekerekített végű ezüst pántkarperec. ${ }^{247}$

Marosgombás-Kis-Magura 10. sír (Ro.). Bronz pántkarperec, keskeny pánt, alig lekerekítetten levágott pántvéggel, egy-egy ütött lyukkal. ${ }^{248}$

Mezőberény-Kérhalom 74. sír (Békés m.). Nagyon kicsi bronz pánt, átmérője pont 4 centiméter. A pánt szélessége is csak 4 milliméter, külső oldala pedig domború, az egyik pántvég letörött és hiányzik. ${ }^{249}$

Mezőmegyer (Békés m.). Kerepeczki J. tanyájának közelében rozettás lószerszámos sírban két darab ezüst, egyik végén kikerekedő, másik végén egyenesre levágott „ruhaszorító" pántkarperec.250

Mezőtúr-Alsórévai határ (Szolnok m.). Kikerekedő végű, ezüst pántkarperec női sírból. ${ }^{251}$

Mezőzombor-Bálványhegy 2., 4. sír (Borsod-Abaúj-Zemplén m.). 2. sír: keskeny, 9 milliméter széles ezüst pántkarperec, kiszélesedő és kikerekedő pántvéggel. 4. sír: ezüst pántkarperec, pántszélesség: 13 milliméter, pántvégek kikerekednek és rozettás rátéttel díszítettek, melyeket 3-3 szegeccsel erősítettek fel a pántvégekre. A pánton poncolt félpalmettákból álló inda húzódik végig, felülete aranyozott volt, amely ma már inkább csak a poncok alján maradt meg (I. t. 1., 3.). Szórvány, ezüst, kikerekedő végű pántkarperec, csepp alakú rovátkolt szegélyű rátéttel, és rátét nélküli ezüst, kikerekedő végű pántkarperec, pántján egy szakaszon kis kerek poncok több sorban beütve. ${ }^{252}$

Mindszent (Csongrád m.). „Mindszentröl 1902-ben szórványként két rosszezüst lemezkarkötő” került elö, lekerekedő végüek a természetesnél kisebb rajz szerint. ${ }^{253}$

Molnos (ma: Mlynarce, Sl.). Lovas sírból keskeny bronz pántból lekerekedő végű karperec, a halott neme azonban kérdéses. 254

Nagykamarás-Rózsamajor (másként Bánkút, Békés m.). Két darab pántkarperec 7 milliméter széles, vékony ezüstlemezből, a pántvégek kiszélesednek 2-2 millimétert, és kis ívben zárulnak. ${ }^{255}$

Nagykáta (Pest m.). Ezüst pántkarperec enyhén kikerekedő végekkel, rajtuk csepp alakú, rovátkolt szegélyú rátéttel, melynek közepén kék üvegpaszta betét van (I. t. 5.). ${ }^{256}$

Nagyrév (Szolnok m.). Ezüst pántkarperec kiszélesedő és kikerekedő végekkel. ${ }^{257}$

Nagyszokoly (Tolna m.). Férfi sír mellékleteként széles ezüstpánt kikerekedő végekkel, négy darab Provencei Hugó (926-945) pénz keltezi (II. t. 1.). ${ }^{258}$

Nagyteremia (ma:Teremia Mare, Ro.). Gazdag női sírból ezüst pántkarperec, mérsékelten kiszélesedő pántjának végei tompa csúcsban zárulnak. A három pánttöredék Hampel szerint egy 12 centiméter átmérőú pánthoz tartozik, de valószínúbb, hogy két kisebb, de hiányos pántról lehet szó. ${ }^{259}$

Nagytőke-Jámborhalom (Szentes-Kunszentmártoni út néven is, Csongrád m.). Rozettás lószerszámos női sír tartozékaként vastag ezüstlemezből készült karperec, oválisan kikerekedő végein egykor ráforrasztott rátét helyének nyomaival. 260

Nagytőke-Jámborhalom, Németh Gergely földje (Csongrád m.). Szórványként elökerült ezüst pántkarperec, pántja lapos, háromszög metszetű, kikerekedő végein két-két ütött lyukkal.261

Nagyvázsony-Nőzsér A. sír (Veszprém m.). Rozettás lószerszámos női sírból való kikerekedő végű, fehérfém pántkarperec. ${ }^{262}$

Naszvad-Babicz kút (ma: Nesvady, Sl.). Vörösréz lemezböl készült pántkarperec, egymásra hajtott végei vékonyra vannak kalapálva, karéjosan kiszélesednek, a pántszélek elnagyoltan, csipkézetten vannak levágva. ${ }^{263}$

247 HAMPEL 1900, 652-653, 66. t.; KISS 1985, 260.

248 Roska 1936, 164-166; KISS 1985, 259; GÁLL 2013, 324, 161. t.

249 KÜRTI 1973, 61; MRT 1998, 601, 9/137. lelőhely

250 BanNer 1943, 172-175, 57. t.; KISS 1985, 260.

251 FehÉR - ÉRY - KralovánsZKY 1962, 660. tétel; KISS 1985, 260.

252 MeGAY 1963, 41-43, 48; KovÁCS 2015, 21, 24, 27.1, 3-4. t.; KISS 1985, 260.

253 SzÉl. 1942, 128-134, 9. t. 19, 29.; KISS 1985, 260.

254 SZŐKE 1954, 122; ToČIK 1968, 37, 20. t. 44; KISS 1985, 260.

255 BÁLINT 1932, 259-260, 51. t. 36, 39; KISS 1985, 261.

256 Hampel 1892, 379; Dienes 1972, 51. kép; Kiss 1985, 261.

257 HAMPEL 1900, 722-723, 99. t.

258 Mészáros 1962, 5; KISS 1985, 261; Ódor 1999, 158.

259 HAMPEL $1900,668,76$. t.

260 Csallány 1905, 34; Hampel 1907, 122; Kiss 1985, 261.

261 FehÉr - Éry - KralovánsZky 1962, 728. tétel; BÁlint 1991, no. 277.; KISS 1985, 261.

262 MRT 1969, 138-139; KISS 1985, 261.

263 SZÖKE 1954, 124; KISS 1985, 261. 
Neszmély-Meleges hegy (Komárom-Esztergom m.). Ezüst pántkarperec, végei kikerekednek és egymást részben takarják. A karperec feltehetően férfi sírból származik, vele együtt övvereteket és Berengár imperator denárát is ajándékozták a MNM-nak. ${ }^{264}$

Ócsa-Alsópakony (Pest m.). Vastag ezüstlemezből kivágott pántkarperec, végei tárcsa-szerűen kikerekednek, csak az egyik pántvég van meg ütött lyukkal. ${ }^{265}$

Oros, 4025-ös objektum (Szabolcs-Szatmár-Bereg m.). Végei felé kiszélesedő és egyenesen levágott ezüstpánt. A pántvég sarkai lekerekítettek. ${ }^{266}$

Oroszlámos (ma: Banatsko Arandjelovo, Srb.). A vasútállomásnál előkerült szórványleletek közül 93/1903. számú bronz pántkarperec, kiszélesedő és kikerekedő végein hátulról domborított rátét utánzat és a pántszél közvetlen közelében egy-egy ütött lyuk. A pánt és a kikerekedő pántvég között egyenesen bevágott nyak van, amely néhány keskenyebb pánton figyelhető csak meg, mint Budapest-Soroksár (I. t. 6.). ${ }^{267}$ 91-92/1903. számú pántkarperecek ezüstből, csepp alakú aranyozott ezüst rátéttel, mindegyik rátét három-három szegeccsel van felerősítve. A rátét gyöngyözött kerettel és középen üvegpaszta betéttel díszített. ${ }^{268}$ 94/1903. és 141/1909. számú ezüst pántkarperecek, mindkettő kikerekedő végü, de csak az előbbinek a pántvégén van egy-egy ütött lyuk, a másiknak viszont alig észrevehetően háromkaréjos a vége. ${ }^{269}$

Öcsöd (Szolnok m.). A Mogyoróshalmon férfi sírból előkerült keskeny bronzpánt karperec, külső oldala domborított, végei enyhén kiszélesednek és csúcsban végződnek, a két pántvég egymást fedi. ${ }^{270}$

Pétervására-Laktanya (Heves m.). Női sírból ezüst pántkarperec, kissé kikerekedő, a pántvég alig szélesebb a pánt középső szakaszánál, átlyukasztott végekkel. ${ }^{271}$

Piliny-Sirmányhegy 64. sír (Nógrád m.). Vas pántkarperec, kikerekedő végekkel, egyik pántvég hiányos. ${ }^{272}$

Rakamaz-Belterület (Szabolcs-Szatmár-Bereg m.). Női sírból, ezüst pánt, végei kikerekednek, mellette áttört korong stb. ${ }^{273}$

Ratnóc (ma: Ratnovce, Sl., egykor Nyitra m.). J. Eisner gyarapodási szemléje szerint „...dva plechova naramky typu belobrdského s elipsovičě rozšiřenymi konci."274

Rád-Kishegy A. sír (Nógrád m.). Ezüst pántkarperec, kiszélesedő és félkörben lekerekedő, elvékonyodó pántvéggel. ${ }^{275}$

Sarkad-Peckesvár (egykor Bihar, ma Békés m.). Fettich Nándornál bronz, a valóságban ezüst pántkarperec, kiszélesedő végein rovátkolt szegélyü üvegbetétes rátét van. ${ }^{276}$

Sajtény 1. sír (ma: Seitin, Ro.). Férfi sírból, övveretek társaságában, 16 milliméterre kiszélesedő végű bronz pántkarperec, a pántvég egyenesen levágva, a sarkok lekerekítve (II. t. 10.). ${ }^{277}$

Sajólád (Borsod-Abaúj-Zemplén m.). Szórvány bronzlemez karperec, pántja enyhén kiszélesedik, egyenesen levágott végén a sarkok lekerekítettek, a pánt felületén a pántvégeken kígyófejre emlékeztető poncolt minta, a pánton két sorban alul és felül háromszögek sora látszik (I. t. 7.). ${ }^{278}$

Sárazsadány (Borsod-Abaúj-Zemplén m.). Keskeny bronzpánt, végei enyhén kiszélesednek, egyik vég jobban lekerekedő, másik inkább egyenesen levágott, és a sarkok lekerekítettek. ${ }^{279}$

Sárospatak-Baksahomok 2., 3., 7. sír (Borsod-Abaúj-Zemplén m.). 2. sír: lovas íjász férfi sírjában keskeny ezüstpánt, mindkét végen lekerekített, kis méretű. A sírt Nasr ibn Ahmed szamanida emír 918/919-ben vert dirheme keltezi. 3. sír: keskeny ezüstpánt, egyik vége kissé kiszélesedik és kis ívben lekerekített, másik pántvég csonka. 7. sír: kiszélesedő végű bronzpánt, a pántvég tompaszögben záródik, a középvonal mentén gerincelt.280

Sárrétudvari-Hízóföld 33. és 167. sír (Hajdú-Bihar m.). Előbbi keskeny (10 milliméter) bronz pánt, egyenletes szélességű, de a pántszélek eldolgozatlanok, a végek részben félkörösen, részben szögletesen levágva, egy-

264 HAMPEL 1900, 552, 17. t.; KISS 1985, 261.

265 KISS 1985, 261.

266 ЈАКАВ 2017, 46-49.

267 Hampel 1907, 20. t.; KISS 1985, 258; KováCs 1993, 44, 55, 71. jegyzet, 26. t.; Stanojev 1989, no. 38.

268 HAMPEL 1907, 21. t.; KovÁCS 1993, 44, 27. t.; StANOJEV 1989, no. 65-66.

269 HAMPEL 1907, 20, csak azt mutatja be, amelyiken ütött lyuk van, ebben követi StANOJEv 1989, no. 39; KovÁCS 1993, 45, 49, 28. t., 32. t.

270 CSALlány 1899, 42, 1.B. kép; Hampel 1905, II. 656-657, III. 431. t.

271 RéVÉSz 2008, 262, 64. t.; Kıss 1985, 261, Pétervására-Vár lelőhely név alatt.

272 HAMPEL 1907, 183, 70. t.; KISS 1985, 261.

273 CSALLÁNy 1959, 284, 8. kép 16.; KIss 1985, 262.

274 EISNER 1935, 79. Ezt a lelőhelyet eddig nem tartotta nyilván a magyar szakirodalom.

275 Patay 1957, 60, XI. t. 1.; KISS 1985, 261.

276 Fettich 1931, 74; Dienes 1972, 84, 51. kép; Katalógus 1996, 347; Kiss 1985, 262.

277 KISS 1985, 262; GÁlL 2013, 439, 229. t.

278 RÉvÉSz 1992, 166, 5. ábra; KISS 1985, 262.

279 MNM Itsz. 62.67.1.A.; Kıss 1985, 262.

280 KISs 1985, 262. 
egy lyukkal átütve (II. t. 9.). A 167. sír karperece 1,6 centiméter széles ezüstpántból készült, egyenletes szélességú pántjának vége félkörösen lekerekített, egy-egy szeglyukkal hátulról áttörve, a szeglyukak körül kör alakú karika lenyomat látszik (I. t. 8.). ${ }^{281}$

Sárrétudvari-Balázshalom (Hajdú-Bihar m.). Keskeny ezüstpánt, végei közül egyik hiányzik, a meglevő 1 centiméteren belül kiszélesedik, tompa szögben záródik és ütött lyuk van rajta. 282

Sikló (ma: Siclau, Ro.). A 2. számú (férfi) sírban keskeny bronzpánt, sajnos pont a pántvéget nem rajzolta le Gáll Erwin. Jelenleg több töredékre szétesve. ${ }^{283}$

Solt-Tételhegy (Bács-Kiskun m.). Ezüstlemez karperec, egymásra hajló, kikerekedő végekkel, ,"a kihajló részen tojásdad lapos dudorodás, melynek egyike kicsorbult", írja Hampel a rátétutánzatról. ${ }^{284}$

Sóshartyán-Mura-hegy 1. sír (Nógrád m.). Kiszélesedő és lekerekített végű ezüst pántkarperec. ${ }^{285}$

Sóshartyán-Zudótető (Nógrád m.). Gádor Judit ásatásából „,bronzlemezből készült karperec," de a pántvéget nem említi. 286

Szabadegyháza (Fejér m.). „egymásra hajló, lekerekített végü, díszítetlen ezüst lemezkarperec”, mellette 12 darab Berengár, köztük 3 darab Berengár imperator (915-924) denár, lószerszám. ${ }^{287}$

Szabadkígyós-Pál ligeti tábla 1. sír (Békés m.). Szablyás férfi sírból ezüst pántkarperec, az ásató szerint öntött munka. A pántvég kiszélesedik és a levágáskor képződött sarkakat lekerekítették. ${ }^{288}$

Szakony-Kavicsbánya 1. sír (Győr-Sopron-Moson m.). Férfi sírból keskeny ezüstpánt karperec, a pántvégek enyhén kiszélesednek és tompa hegyben zárulnak (II. t. 8.). A sírban veretes lószerszám és hét nyílcsúcs is volt. ${ }^{289}$

Szedres-Ifigénia-puszta (korábban Fácánkert, Kajmád-puszta, Iphigénia major, Tolna m.). A csontváz bal karján ezüstlemezből készült karperec, mely azonban darabokra törött. Ódor János megjegyzése szerint a töredékek nem igazi karperecre utalnak, hanem pótlék pántra. 290

Szeged-Felsőváros, Fekete földek (Csongrád m.). Bálint szerint: „Fragmente eines Armbandes mit Ornament und ein kleines Beil." A leletkataszter nem tud karperecröl.291

Szeged-Királyhalom-Rívó (ma: Ásotthalom-Rívó, Csongrád m.). Ezüst pántkarperec töredéke, valószínűleg kiszélesedő és kikerekedő pántvég, de a kikerekedő résznek legalább a fele letörött, ezért Hampel egyenesen levágottnak értékelte. A pántvég középvonalának mindkét oldalán egy-egy hosszú csepp vagy levél alakú díszítés, a sajóládi pántvégre emlékeztet. A feltehetően egy sírleletben Ismail ibn Ahmed 906-os dirheme volt ${ }^{292}$

Szeged-Öthalom 1879/39., 41. sír (Csongrád m.). 39. sír: karperec vékony ezüstből, hasonló a galgócihoz. 293 41. sír: vastag ezüstlemezből készült karperec, hasonló a verebihez. Pántja kissé kiszélesedő, egyenesen levágott, és a sarkokon lekerekített pánt. ${ }^{294} \mathrm{Az}$ 1950-ben előkerült 5. sírban bronz lemezkarperec volt, kikerekedő végén hátulról domborított, a szegély szélén vezetett dudor-sor rajzolt ki egy csepp alakú díszítést, és ezen belül egy nagy csepp, vagy mandula alakú domborulat szolgált egy rátét díszítés imitációjaként. A pontsor és a pánt szegélye közt, a pontsorba illesztve egy-egy áttört lyuk látható. ${ }^{295} \mathrm{Az}$ Öthalom harmadik lelőhelyéről az V. homokbánya területéről való 36. sírban 5 milliméter széles ezüstpánt karperec jött elő, végei kissé elhegyesedők, illetve hiányosak. ${ }^{296}$

281 NePPER 2002, 302, 232. t. 14., 332, 293. t.

282 MeStERHÁZy 1978, 40; Kiss 1985, 262.

283 KIss 1985, 262, hibásan 11-es sírszámot ír, ami egy római 2-esből is származhat. GÁlL 2013, 445, 235. t.

284 Hampel 1907, 137, 27. t.

285 Patay 1957, 60; Katalógus 1996, 406; Kiss 1985, 262.

286 GÁDOR 1969, 51-52; KISS 1985, 262.

287 KRALOVÁNSZKY 1967-68, 249-252; KISS 1985, 262.

288 BÁLINT 1971, 51, 1. t. 8.; KISS 1985, 262.

289 RÉvÉSz 2006, 200-205, Abb. 11.6.; KISS 1985, 262.

290 WoSINSKY 1896, 1036-1038; ÓdOR 1999, 160; KISS 1985, 259.

291 Fehér - ÉRY - Kralovánszky 1962, 953. tétel; BÁlint 1991, 250, no. 244; KISS 1985, 262.

292 Reizner 1891, 99; HAMPel 1900, 528-530; Kiss 1985, 262.

293 VARÁZSÉJ 1880, 54. t. 11. Mivel a galgóci leletben nem volt karperec, ez az adat árulkodó arra nézve, mikortól számolhatunk a leletkeveredéssel.

294 VARÁzSÉJ 1880, 328, 332, 54. t. 12.; Kiss Attila e leletekkel nem foglalkozik, hiszen mint lelöhely szerepelnek nála, bár hibás lelőhely néven.

295 KÜRTI 1983, 12. fénykép, „i" tárgy, 751. oldalon a fényképjegyzékben. Ugyanez a karperec a leletkataszterben hibásan Székkutas-Öthalom néven szerepel, és ezt használja szintén hibásan Kıss 1985, 263. A másik hibát Bálint Csanád követte el, aki ugyanezt a sírt 10. sírként idézi, miután a Varázséji féle sírokat átszámozta, és a karperecet ezüstnek írja: BÁLINT 1968, 58-60. A lelőhely megnevezését javítja Kürti és TürR - LÖRINCZY 2015, 41-42.

296 TÜRK - LÖRINCZY 2015, 27, 76. kép 
Szeged-Kiskundorozsma-Hosszúhát 595. sír (Csongrád m.). Idős nő keskeny, 6 milliméter széles ezüst pántkarperecei, a pánt egyik oldala eldolgozott, a másikon jól láthatók a készítés vágásnyomai. Az egyik karperec pántvégei egyszerủen, sarkosan levágottak, a másikon összeszűkülően lekerekítettek. A pántok jellege és sírban való helyzete a karperec funkciót erősíti. ${ }^{297}$

Szentes-Borbásföld 9. és 14. sír (Csongrád m.). 9. sír: Révész László szerint „négyszög átmetszetü öntött bronz karperec", azaz vaskos bronzlemezből készült, téglalap metszetú pánt, végei egyenesen levágottak, de ez nincs a rajzos táblán ábrázolva. 14. sír: két ezüst pántkarperec, végeik több milliméterrel szélesebbek a pánt középső szakaszánál, az egyik inkább kikerekedő, ezen a pántvégeken egy-egy ütött lyuk, a másik egyenesen levágott és a sarkok lekerekítettek. ${ }^{298}$

Szentes-Derekegyházi oldal, Berényi Benjamin földje, 4. sír (Csongrád m.). Kiszélesedő végü ezüst lemezkarperec, feltehetően lekerekedő véggel, a fényképes táblán élén fekszik, leírása hiányos. ${ }^{299}$

Szentes (Csongrád m.). „,A 391. sz. tanyán talált pántkarperec."1300

Szentes-Kistőke-Székhát, Búza Pál 222. sz. tanyája (Csongrád m.). Széll Márta szűkszavú leírása szerint 1932ben egy sírból egy lemezes bronz és csavart karperec került elő, de jegyzetben megjegyzi, hogy a Szentesszentlászlói 93. sír karperecével egyezik meg. A szentlászlói 95. sírban valóban volt pántkarperec gyengén kiszélesedő és lekerekedő pántvéggel, és mindkét pántvégen ütött lyuk volt. ${ }^{301}$

Szentes-Szentlászló 74. és 95. sír (Csongrád m.). 74. sír: a jobb karon lemezkarperec" anyagáról nem szól, táblarajza szerint keskeny pánt, kiszélesedő és kikerekedő véggel, rajta egy-egy ütött lyukkal. 95. sír: a jobb alkaron bronz lemezkarperec, a táblarajz szerint az egyik pántvég lekerekedő, a másik inkább kikerekedő, de ezeken is egy-egy ütött lyuk látható. ${ }^{302}$

Szered (ma: Sered, SI.). I. temetőből szórvány ezüst pántkarperec, egyenletes pántszélességü, lekerekített végekkel. ${ }^{303}$

Szered (ma: Sered, SI.). II. temető. 5/54. sír: keskeny, 1 centiméter széles bronzpánt férfi sírból, végei lekerekítettek, egyéb melléklet: vas nyílcsúcsok, kengyel (II. t. 5.). 6/54. sír: keskeny, 8 milliméter széles ezüst pánt, végei lekerekítettek. ${ }^{304} 2 / 55$. sír: férfi sír, 1 centiméter széles bronzpánt, lekerekedő végekkel. 4/55. sír: egyenletes szélességű, keskeny 7 milliméter széles bronzpánt, mindkét vége nagyjából derékszögú csúcsban végződik. A férfi sírjában tegez és nyílcsúcsok is voltak. 8/55. sír: enyhén kiszélesedő és lekerekített bronzpánt, mellette I. Henrik német király (919-936) denárával. ${ }^{305}$

Szinyér (ma: Svinice, SI.). Ezüst pántkarperec, kiszélesedő és kikerekedő véggel, a pántvégek közelében egyegy lyukkal. ${ }^{306}$

Szob-Ipolyparti temető 13. sír (Pest m.). Bronz pánt, egyik vége sincs meg, a töredéken poncolt, kettős vonalú háromszögsor látható, ami ritkán, de kikerekedő végű karpereceken is előfordul. ${ }^{307}$

Szolnok-Lenin tsz. 7. sír (Szolnok m.). A férfi lovas sírban a jobb combcsont alsó harmadában pántkarperecek rátét dísze került elö önállóan, ismeretlen funkcióban, karperec nélkül. ${ }^{308}$

Szolnok-Beke Pál halma III. temető 5. sír (Szolnok m.). Női sírból bronz pántkarperec, kiszélesedő és kikerekedő végén egy-egy lyukkal. ${ }^{309}$

Szolnok-Szanda, Kiss János u. 11. (Szolnok m.). Háton fekvő, nyújtott váznál két bronz lemezkarperec, a pántvégek leírása nélkül. ${ }^{310}$

Szolyva (ma: Svaljava, U.). Tarsolylemezes férfi sírból ezüst pántkarperec, végei felé kiszélesedő és kis ívben lekerekedő pánttal. ${ }^{311}$

Tengelic-Középhídvég, Bernwieder József pusztája (Tolna m.) Kikerekedő végű ezüst lemezkarperec. ${ }^{312}$

297 TÜRK - LÖRINCZY 2015, 20, 68-69, 41. kép

298 Révész 1996b, 301, 9. kép, 301, 12. kép 35-36; Kıss 1985, 263.

299 CSALLÁNY 1941, 183, II. t. 11.; KISS 1985, 263.

300 FehÉr - Éry - KRALovánSZKY 1962, 1029. tétel; KISS 1985, 263.

301 SzÉlL 1942, 132, X. t. 26.; KISS 1985, 263.

302 Szél. 1941, 238, VI. t. A. 10 a-b., VIII. t. A. 9.; KIss 1985, 263.

303 Тос̆ıк 1968, 48, 38. t. 10.; KIss 1985, 262.

304 ToČıK 1968, 50, 43. t. 11., 51, 43. t. 12.; KIss 1985, 262.

305 Тос̆ıк 1968, 53, 45. t. 11., 53, 45. t. 21., 55, 47. t. 19.; KIss 1985, 262.

306 HaMPEL 1907, 145, 32. t.

307 BAKAY 1978, 53, 29. t. 23.

308 MadARAS 1996, 67, VII. t. 4.

309 MaDARAS 2006, 320, 343, 6. kép 8.

310 MadARAS $1978,81$.

311 LeHOCZKY 1870, 201-206; HAMPel 1900, 709, 93. t.; KISS 1985, 263.

312 WoSINSKY 1896, 1040; ÓDOR 1999, 163, no. 64; KIsS 1985, 260. 
Tengelic (vagy Kistengelic, Tolna m.). 1896-ban a Nemzeti Múzeumba került egy kiszélesedő és egyenesen levágott végú, a sarkain lekerekített ezüst lemezkarperec.313

Tibolddaróc (Borsod-Abaúj-Zemplén m.). „... két bronzkargyürü és egy harmadik töredéke: az egyiken szépen kivitelezett szalagdíszítés. A végeik kissé kiszélesednek és lekerekítettek." Utal a hasonló szolyvai, verebi és szegedöthalmi karperecekre. ${ }^{314}$

Tiszaeszlár-Vörösmarty u. 2. sír (Szabolcs-Szatmár-Bereg m.). Női sírból sima, kiszélesedő és egyenesen levágott, de lekerekített sarkú ezüst pántkarperec. ${ }^{315}$

Tiszajenö-Eperjesi telep 4. sír (Szolnok m.). A női váz mindkét csuklóján egy-egy ezüstlemez karperec, a pántvég csak az egyiknél van megemlítve, az pödrött végú, a másik feltehetően ki-vagy lekerekedő típus. ${ }^{316}$

Tiszakécske (a lelőhely korábban Újkécske, Szolnok m.). Ezüst pántkarperec, egyenletesen széles pánt, végei lekerekítettek, rajtuk egy-egy lyuk. ${ }^{317}$

Tiszanána-Cseh tanya 2. sír (Heves m.). Ezüst pántkarperec, a pántvégek megnyúlt ovális formában kissé kiszélesednek, rajtuk egy-egy apró lyuk. ${ }^{318}$

Tiszapüspöki (Szolnok m.). A bal alkar közepén bronzlemez karperec, keskeny 7 milliméteres pánt, egyik vége kissé kiszélesedik és kikerekedik, a másik szintén kiszélesedik és a szabályos hatszög három oldalával zárul. Mindegyik pántvégen egy-egy ütött lyuk. ${ }^{319}$

Tiszaszederkény 1. sír (Borsod-Abaúj-Zemplén m.). Ezüstlemez karperec, 8 milliméter keskeny pántja kissé kiszélesedik és lekerekített. Ugyaninnen már korábban is megmentettek egy sírt két bronz pántkarpereccel. ${ }^{320}$

Tiszavasvári-Aranykerti tábla 13. sír (Szabolcs-Szatmár-Bereg m.). Ezüst pántkarperec, keskeny pántból, egyik vége egyenesen levágva, másik kis ívben lekerekített. Mindkét pántvégen egy-egy lyuk. ${ }^{321}$

Törtel (Pest m.). Rozettás lószerszámos női sírból ezüst pántkarperec, végei kissé kiszélesednek és félkörben lekerekednek. ${ }^{322}$

Tornóc 480. sír (ma: Trnovec nad Vahom, Sl.). Kiszélesedő és kikerekedő bronzpánt, bár a közölt fényképről a pántvég nehezen ítélhető meg, a sírleírás pedig hiányos. ${ }^{323}$

Velence (Fejér m.). „Velencéről származik állítólag a múzeum két pántos karperece ezüstből(?), az egyik kerekdeden kihajló a másik egyenesre vágott végekkel.'324

Vereb (Fejér m.). Az első honfoglaló magyar pántkarperec, ráadásul férfi sírból. Ezüst pánt, a végei felé kb. 2 milliméterrel kiszélesedik és félkörben lekerekedik. ${ }^{325}$

Veszkény-Tormostyán-dülő (Győr-Sopron-Moson m.). Három lovas sír egyikéből ezüst karperec jött elő. Csak vélelmezzük, hogy pántkarperec lehetett. ${ }^{326}$

Vésztő-Kót-puszta (Békés m.). Ezüst lemezből készült karperec, s bár a pántvégekről nem szól az ásató, Kovalovszki Júlia, a szarvasi karperec közlésekor azt írta a pántkarperecekről egy jegyzetben, hogy "Nagy részük emellett nyitott, de akad közöttük zárható is. Utóbbiak közül néhányat a végein keresztül kötötték át", és itt jegyzetben megemlíti a vésztő-kót-pusztai karperecet. És hogy egyértelmúbb legyen a kótpusztai jellege, nevezetesen, hogy kikerekedő és átlyukasztott végü, megemlíti, hogy más karperecek mindkét végét teljes szélességükben megpödrötték, s ezeken a csövecskéken át füzve valamiféle huzallal kötötték össze őket, ${ }^{327}$ mondja Hampel nyomán.

Vörs-Papkert "B" 395. és 690. sír. Előzetes ásatási beszámoló illusztrációjaként néhány sír anyagát mutatták be az ásatók. A nevezett két sírban pántkarpereceket láthatunk, keskeny pántokat félkörösen lekerekedő végekkel, és egy mérsékelten kikerekedő példány rajzát. Anyaguk ismeretlen, leírás sem készült róluk. ${ }^{328}$

\footnotetext{
313 HAMPEL 1900, 651, 65. t. 4.; ÓDOR 1999, 163, no. 63a; KIss 1985, 263.

314 NeEs 1932-33, 174, 95. kép a-e.

315 CSALLÁnY 1970, 206, 32. t.

316 Selmeczi 1996, 117, és 10. jegyzet; KIss 1985, 263.

317 MNM Itsz. 5/1932.2.; Fehér - ÉRY - Kralovánszky 1962, 1122. tétel; Kiss 1985, 263.

318 Révész 2008, 286, 73. t.; Kıss 1985, 263.

319 FODOR - KERTÉSZ 2015, 259-260, 3. kép

320 K. VÉGH 1992, 62-63, 2. kép 3.; K. VÉGH 1970, 86-87, 9. t. 1-2.

321 Тоттн 2014, 139, 102.t. 7.

322 Pósta 1896, 30-39; Hampel 1900, 726, 101. t.; Kiss 1985, 263.

323 Toс̌ı 1971, 176, 42. t. 21.

324 Marosi 1914, 63.

325 ÉRDY 1858, 14-27; HAMPEL 1900, 562, 22. t.; KISS 1985, 263.

326 Novákı 1959, 53; FeHÉR - ÉRY - KralovánszkY 1962, 1200. tétel; KIss 1985, 263.

327 Kovalovszkı 1960, 177, és 19. jegyzet. Az ásatásról ugyanő adott leírást a Békés megyei topográfia megfelelő kötetében: MRT 1982, 206;

KIss 1985, 264.

328 KöLtô - SZENTPÉTERI 2001, 3. t. 25-26., 4. t. 20.
} 
Zalkod-Szegfarka (Szabolcs-Szatmár-Bereg m.). Egyenletes szélességű, keskenyebb ezüstpánt félkörben lekerekedő végekkel, melyek egymást keresztezve fedik. ${ }^{329}$

\section{Pántkarperecek pontkörös díszítéssel}

Arad-Földvári-puszta (ma: Zimándúffalu, Ro.). Oválisan kikerekedő végú bronz pántkarperec, a pontkörök a pánt alsó és felső szélén húzódnak, a pántvégen érnek össze, a belső hurokban négy pontkörös beütés tölti ki a teret. ${ }^{330}$

Bakonszeg-Kovácsi (Hajdú-Bihar m.). Kiszélesedő és félkörben lekerekedő bronzpánt, a pántvégeken egyegy pontkörös beütés, ezt két sorban követi a többi. ${ }^{331}$

Brestovik (Srb.). Kikerekedő végú bronz pántkarperec, a pánton három sorban ponckörös beütések. 332

Csákberény-Öregtó, Lóállási legelő (Fejér m.). A 21. sírban „pántos lemezü karperec”, bronzból, a pántvégek kiszélesednek és félkörben záródnak. A pántvégeken keresztben négy pontkörös beütést követ két sor ponc, majd a másik pántvégen a két pontsor kétszer három sorosra vált, majd egy pontkörös beütéssel zár. ${ }^{333}$

Csanytelek-Dilitor 61. sír (Csongrád m.). Mindkét karon vékony bronzpánt, egyik vége kikerekedő alapformát utánoz szögletes formákkal, másik pántvég enyhén kiszélesedve kerekedik le. A szögletes pántvégen két poncbeütés van egymás alatt, ezt követi egy sor végig a pánton, és a másik pántvégen kétsorosra vált és egy beponcolással zár. A sírban egy I. István denár negyede volt. ${ }^{334}$

Csölle (ma: Rovinka, SI.). A 16. sírban kikerekedő végü, igénytelen kivitelú bronzpánt, egyik vége sérült. A pánton kétszeres körponcokban ülő pontból áll a szabálytalan sorban elhelyezett díszítés (IV. t. 8.). ${ }^{335}$

Dunaszekcső (Baranya m.). .,Hozzá tartozik (a nyakperechez) egy pántos karperecz sárgarézből, melynek díszítése 2-2 poncolt kör, kis mélyedéssel jelzett középpont körül. A körök sürün következnek egymásra, úgy hogy széleikkel érintkeznek, és a pánt kiszélesedö, kerekded végén két sorban helyezkednek el. A karperec egyik vége hiányzik."336

Fábiánsebestyén, Molnár F. F. tanya 4. sír (Csongrád m.). Kikerekedő végű bronzpánt egysoros kettőskörös poncbeütéssel díszítve. A pántvégeken keresztben álló négy ponccal töltötték ki a kiszélesedő felületet (IV. t. 1.). A szomszédos 5. sírban I. András denára volt. 337

Gyulafehérvár-Brandusei u. 137. sír (ma: Alba lulia, Ro.). Kikerekedő végú bronzpánt karperec, egysoros, de kétszeres egybeírt körökkel és ponttal díszítve, a pántvégeken négy-négy beütés van párosával. Mellette I. András denára volt fonott ezüstgyűrűvel. ${ }^{338}$

Hajdúszoboszló-Árkos halom 14. sír (Hajdú-Bihar m.). Egyenletes szélességü, keskeny bronzpánt, lekerekedő végekkel, kétszeres koncentrikus körben ponttal egysoros díszítéssel. ${ }^{339}$

Homokmégy-Székes 229. sír (Bács-Kiskun m.). Sárgaréz pántkarperec, egyik vége csonka, másik hiányzik. A csonk alapján kikerekedő típus volt. A pánton pontkörökből álló megszakadó inda látható. A pántvégen áttört lyuk nyoma látszik (IV. t. 7.). ${ }^{340}$

Igar-Sósdomb (Fejér m.). „pántos karperec kiszélesített átlyukasztott végekkel”. Anyagát nem közli Marosi, a díszítés dupla körös poncokból áll. ${ }^{341}$

Ismeretlen lelöhely (Szombathely, Smidt Múzeum). Bronz pántkarperec, kikerekedő végekkel, kettős körös ponttal egysoros díszítés az egész pánt hosszában. ${ }^{342}$

Kaba (Hajdú-Bihar m.). Majdnem a pántszélesség kétszeresére kiszélesedő és kikerekedő bronzpánt karperec, egyik vége csonka, egysoros pontkör mintával, amely a kiszélesedésnél kétsorossá válik és öt pontkörös ponccal veszi körbe a pánt szélét. A pontkörök négyszeres körből állnak. ${ }^{343}$

Körösszegapáti-Pál-lapály 6. sír (Hajdú-Bihar m.). Egyenletes szélességú bronzpánt, a pántvégek tompa csúcsban zárulnak. A pánt középvonalában a legvastagabb, metszete nagyon lapos háromszög alakú, a gerinc két oldalán kettős körökből álló pontkörös díszítés két sora látszik (IV. t. 4.). ${ }^{344}$

329 Jósa 1914, 177-178, 5. kép 5.; KIss 1985, 264.

330 Réthy 1898, 128; Kiss 1985, 261; Katalógus 1996, 300-301; Gáll 2013, 551.

331 CSÉPLÖ 1897, 440-441; KISS 1985, 258.

332 BÁlint 1991, 33. t. A. 3.

333 HAMPEL 1907, 162; SzÖKE 1954, XIV. t. 1. Szőke a szövegben nem említi, csak a rajzos típustábláján szerepel a karperec. Kıss $1985,258$.

334 SzÉl. 1941, 252, XII. t. B. 7-8.; KISS 1985, 258.

335 NemejCovÁ-PaVuKová 1962, 660, 225. kép 2.; Kiss 1985, 262.

336 Marosi 1914, 63; FehÉR - ÉRY - KralovánsZKY 1962, 259. tétel; KISS 1985, 259.

337 CSAllány 1905, 41-42; Bálint 1991, 219, 63. t. B. 5-6.; Bende - LÖRINCZY 1997, 228, 26. kép 7.; KISS $1985,259$.

338 GÁLL 2013, 137, 62. t.

339 NEPPER 2002, 61, 27. t.

340 GalLina - VARGA 2016, 117, 165, 102. t.

341 Marosi 1935, 88; FehÉR - ÉRY - KralovánsZKy 1962, 425. tétel; KISS 1985, 260.

342 KIss 2000, 269, 91. t.

343 Hampel 1897, II. 492; Hampel 1905, II. 537-538.

344 Nepper 2002, 124, 115. t. 9, 11.; Katalógus 1996, 251. 
Letkés II. temető 67. sír (Pest m.). Köznépi temetőben négy év körüli gyermek sírjában a jobb alkar helyén találták. Ezüst pántkarperec kiszélesedö, és kissé szögletesre vágott végekkel. A pánton kétsoros pontkörös poncokból álló díszítés, amely a két pántvégen nem szimmetrikus (IV. t. 6.). ${ }^{345}$

Mezőkovácsháza-Templomföldi temető (Békés m.). Vaskos bronzlemez, egyenletes pántszélességú karperec, a pántvégek előtt behúzott-beszűkülő nyak és a pánt szélességében kikerekedő pántvég. A pánt felületén egysoros kettős körökből álló pontkörös poncolt díszítés látható (IV. t. 5.). ${ }^{346}$

Nádudvar-Töröklaponyag 20. sír (Hajdú-Bihar m.). Bronz pánt 8 milliméter szélességú, amely a végein 10-11 milliméterre szélesedik ki, és lekerekedik. A pánton két sorban pontkörös poncolás, az egyik végen keresztben álló négy, a másikon hármas ponccal lezárva. A pánt szélei a pánt kivágásának szakaszait eldolgozatlanul mutatják (IV. t. 2.). ${ }^{347}$

Nagykapornak (Zala m.). Két darab bronz pántkarperec. Az egyik kiszélesedő végú és félkörben lekerekedő, rajta egysoros pontkörös díszítés, amely az egyik pántvégen hármas pontkörrel indul, és a másik végig egysoros marad. A másik karperec szintén kiszélesedő, de a két pántvég nem szimmetrikus: az egyik vég kis ívben lekerekített, a másik kevésbé szélesedik ki és majdnem kikerekedő. Rajta egysoros pontkör poncolás. ${ }^{348}$

Pusztasomorja-Timárdomb 6. sír (Győr-Moson-Sopron m.). Pusztai Rezső „pontkörös díszü lemezes karperecről" tudósít, Horváth Ciprián szerint lekerekített volt, de elveszett. ${ }^{349}$

Püspökladány-Eperjes 521. sír (Hajdú-Bihar m.). 11-12 éves kislány jobb karján vaskos bronz pántkarperec kikerekedő végekkel, egysoros, de háromszoros koncentrikus körökből és központi pontból álló díszítéssel (IV. t. 3.). ${ }^{350}$

Sármellék-Vasútállomás (Zala m.). Két darab bronz pántkarperecet említenek pontkörös díszítéssel. ${ }^{351}$

Szeged-Makkoserdő 13. sír (Csongrád m.). .,... az egyik karon kis körökkel díszített nyitott bronzlemez karkötö.1352

Taktaharkány (Borsod-Abaúj-Zemplén m.). Bronz pántkarperec hosszan kiszélesedő és félkörben lekerekedő véggel, a pántvégek egymást fedik részben. A pánton egysoros pontkörös díszítés, a pántvég legszélesebb szakaszán kétsoros a körponc. ${ }^{353}$

Tiszadob-Sós-szék 3. sír (Szabolcs-Szatmár-Bereg m.). Vékony bronzlemezből kivágott pántkarperec nagyjából félköríves töredéke, pontkörökkel díszítve, a pántvégek hiányoznak. ${ }^{354}$

Várfalva 42. sír (Moldovenesti, Ro.). Bronz pánt, középen 7 milliméter széles, a végeken 13 milliméterre szélesedik ki, majd félkörben záródik. A pántvégeken kétsoros, a keskenyebb szakaszon egysoros pontkörös díszítés. A pántvégek szélén egy-egy lyuk. A temető 11. század elejéről való sírcsoportjában (IV. t. 10.). ${ }^{355}$

Bezdéd 14. sír (Szabolcs-Szatmár-Bereg m.). Pödrött végú bronzpánt karperec, rajta három sorban teljesen egyforma körponcok. A pánt anyaga vitatott, Jósa még rosszezüstnek vélte. ${ }^{356}$

Galánta-Papföld (SI.). Pödrött végủ bronzpánt, rajta két sorban körponcok vagy pontkörös díszítés. ${ }^{357}$

Kistokaj-Gerenda-dülő 4. sír (Borsod-Abaúj-Zemplén m.). Ezüst pödrött végú pántkarperec, rajta váltakozóan egy és két pontkörös poncok sora (IV. t. 9.). ${ }^{358}$

\section{Pödrött végü pántkarperecek}

Aldebrö-Mocsáros 13. és 20. sír (Heves m.). 13. sír: hajfonatkorongos sírban bronz pödrött végủ karperec több töredéke, a pántvég keskenyedik. 20. sír: két keskeny pödrött végú ezüstpánt, lábperec. ${ }^{359}$

Ároktő-Dongóhalom (Borsod-Abaúj-Zemplén m.). Állítólag azonos sírból került elő egy vékony bronzlemez karperec, egyik vége letörött, másik bepödrött, és egy bordázott $S$ végú karika. ${ }^{360}$

Bánkeszi 18. sír (ma: Bánov, Sl.). Keskeny, 9 milliméter széles ezüstpánt, végig egyenletesen széles, töredékes. ${ }^{361}$

\footnotetext{
345 BAKAY 1978, 113, 53. t. 23.

346 BAKAY 1978, 69. t. 9.

347 MesteRHÁZY 1968, 136, II. t. 12: élére fektetett pánt; KISS 1985, 261.

348 Darnay 1907, 191; Hampel 1907, 176, 64. t.; Kiss 1985, 261.

349 Pusztal 1969, 67; Horváth 2014, 188; KISs 1985, 261.

350 Nepper 2002, 201, 213. t.; KatalóGus 1996, 251.

351 Fehér - ÉRY - Kralovánszky 1962, 871. tétel; MRt 1968, 138; Kiss 1985, 262.

352 SzÉlL 1940, 165, 30. t. 19 a-b.; KüRTı 1983, 35. grafikai melléklet; Kıss 1985, 262.

353 KovÁcs 2015, 47-48, 27. kép

354 ЈАКАВ 2014, 278, 290, 117.t. 3.

355 Roska 1914, 140, 7. kép 9.; Gáll 2013, 529, 284. t. 5.

356 JósA 1896, 405-406; Révész 2003, 213, 212. t.; KIss 1985, 263.

357 Točı̌ 1992, 149, 93. ábra 19.

358 K. VÉGH 1993, 54, 5. kép 6.

359 RÉvész 2008, 23, 3. t. 28., 8. t.

360 K. VÉGH 1970, 85, III. t. 1.

361 Тос̆ік 1968, 12, 3. t. 24.
} 
Békésszentandrás-Pálinkásér (Békés m.). Keskeny, 9 milliméter széles ezüst pántkarperec, pödrött végekkel. ${ }^{362}$ Bihar-Somlyóhegy 5. sír (Ro.). Lovas sírból bronz(?) pántkarperecek, keskeny pödrött végú pántdarabok és nagyobb pántmaradványok. Egyes veretek férfi sírra vallanak. ${ }^{363}$

Biharkeresztes-Bethlen G. u. 1. sír (Hajdú-Bihar m.). Pödrött végú bronz pántkarperec, rajta rezgő vonalú, fáziseltolódással bekarcolt széles zeg-zug minta, amely így fekvő rombuszokat alkot. A rombuszok belsejében kerek poncokból rozetták vannak (VI. t. 6.). Viszonylag jó párhuzama Csekejről való. A sírba szvasztika díszes hajfonatkorongok, rombusz alakú ingnyak díszek, és egy kikerekedő és egy-egy lyukkal átütött végú pántkarperec is volt. ${ }^{364}$

Csákvár-Rókahegy (Fejér m.). Pödrött végú pántkarperec, anyagát nem említik. ${ }^{365}$

Csekej 336. sír (ma: Čakajovce, SI.). Bronz pánt, a pántvégek a belső oldalra csavarodnak be, és mindegyik tekercsben egy-egy vékony ezüstkarika. A másik karperecnek csak töredékei vannak meg, rajtuk rezgővonalú rombusz minta, a rombuszok belsejében egy-egy pontkörös ponc (VI. t. 5.). ${ }^{366}$

Csetény-Szőlőhegy 19. sír (Veszprém m.). Lapos bronz karperec, a táblarajz szerint pödrött végú pánt. Mellette cyprea csiga, bronz hajkarika, négy szem gyöngy voltak. ${ }^{367}$

Eger-Szépasszonyvölgy (Heves m.). A számos szórványnak minősülő karperec között van egy bronz pödrött végú pántkarperec is. ${ }^{368}$

Gálospetri (ma: Galospetreu, Ro.). Női sírból bepödrött bronz pántkarperec, mellette két áttört öntött hajfonatkorong és egy edény voltak. ${ }^{369}$

Génye 7. sír (ma: Geňa, SI.). A jobb karcsonton a könyöknél bronz pánt, félpalmettás indadíszítéssel (VI. t. 2.). ${ }^{370}$

Gombos (ma: Bogojeva, Srb.). A jobb kéz alsó szárán, a könyökhöz közel bronz lemez karperec, 14 milliméter széles pánt bepödrött végekkel. ${ }^{371}$

Gyomaendrőd-Kádár tanya A sír (Békés m.). Pödrött végű ezüst pántkarperec női sírból. ${ }^{372}$

Gyulafehérvár-Mentőállomás (ma: Alba lulia, Ro.). Sírszám nélkül említett pödrött végű bronzkarperec. ${ }^{373}$

Gyulavarsánd-Laposhalom 15/1949. sír (ma: Varsand, Ro.). Ép és töredékes bronz pántkarperecek pödrött véggel. ${ }^{374}$

Harta-Miklapuszta 1. sír (Bács-Kiskun m.). Bronz pánt, egyik vége hiányzik. ${ }^{375}$

Ipolykiskeszi 104., 203., 256., 301. sír (ma: Malé Kossíhy, Sl.). 104. sír: nő hajfonatkorongokkal, ezüst karpereccel. 203. sír: bronz pántkarperec, végei egymásra érnek. 256. sír: ezüst pödrött végű félpánt. 301. sír: bronz pántkarperec, egyenletes szélességű pántján kettős vonalú, tǔzdelt zeg-zug minta (VI. t. 4.). ${ }^{376}$

Jászberény-Alsómuszáj (Szolnok m.). Pödrött végű bronz pántkarperec, bolygatott sírokból. ${ }^{377}$

Karancslapujtő 1. sír (korábban Bocsárlapujtő, Nógrád m.). Férfi(?) sírból 9 milliméter széles ezüst pántkarperec pödrött végekkel. A sírhoz való tartozása bizonytalan. ${ }^{378}$

Karos II. temető 73. sír (Borsod-Abaúj-Zemplén m.). Bronz pántkarperec, pödrött végü, a végei felé keskenyedő pántból, melynek alsó és felső szélét poncolt vesszősor szegélyezi. ${ }^{379}$

Karos III. temető 5. sír (Borsod-Abaúj-Zemplén m.). Bronz pánt töredékei, a pántvég majdnem a felére keskenyedik, ezt a részt pödörték meg. ${ }^{380}$

362 KreCSMARIK 1913, 33, 7. ábra; MRt 1989, 1/62. lelőhely, 64. t. 21., 65. t. 15.; KISS 1985, 258.

363 KarÁCSONYI 1903, 407, 410; HAMPEL 1907, 106-107, 6. t. 10-12.; GÁlL 2013, 54, 11-12. t.; KISS 1985, 258.

364 Nepper 2002, 28, 2. t.; KatalóGus 1996, 216-217.

365 MAROSI 1936, 43; SZÖKE 1962, 24; KISS 1985, 258.

366 REIHOLCOVÁ 1995, 36, 54. t.

367 MRT 1972, 79-80, 15. t. 32.; KIss 1985, 258.

368 Révész 2008, 112, 38. t. 10. Révész megjegyzi, hogy a pödrött végű karperec ugyan együtt van leltározva a többivel, de nem szerepel

Nagy Árpád feldolgozásában a szépasszonyvölgyi leletek között: RévÉsz 2008, 143. jegyzet

369 CHIDIOSAN 1965, 237; KIsS 1985, 259.

370 NeVIZÁNSZKY 2013, 187, 8. t. 5.

371 CZIRÁKy 1900, 266, II. ábra 3.; Kiss 1985, 258; StAnOJev 1989, 24, no. 122.

372 KovÁcs 2011a, 292, 4. ábra 11.; MRT 1989, 72. t. 8.

373 CiugudeAnu - PinteR - Rustolu 2006, 29, 117. kép

374 MedgyesI 1995, 102, 24. t. 1., 23. t. 1.; GÁll 2013, 214, 96. t.; Kiss 1985, 265.

375 MNM Itsz. 14/1929. FeHÉr - ÉrY - KralovánsZKY 1962, 379. tétel; KIsS 1985, 259.

376 HANULIAK 1994, 122, 23. t., 127, 44. t., 129, 50. t., 131, 61. t.

377 FehÉR - ÉRY - KralovánSZKy 1962, 505. tétel; KISs 1985, 260.

378 DienEs 1964, 22, 3. kép; KIss 1985, 258.

379 Révész 1996b, 32, 110. t. 3.

380 RÉvÉSz 1996b, 34, 114. t. 
Kál-Legelő 20., 35. sír (Heves m.). 20. sír: díszítetlen, pödrött végű bronzpánt. 35. sír: az előbbihez hasonló pödrött végú pántkarperec. ${ }^{381}$

Kecskemét-Lakihegy B. sír (Bács-Kiskun m.). Két bronzpánt karperec, végei felé mindkettő keskenyedik, és inkább csak visszahajlított, mint bepödrött pántvéggel. Az egyik pánton poncolt inda díszítés (VI. t. 1.). ${ }^{382}$

Kiskundorozsma-Jerney téglagyár (Bács-Kiskun m.). Pödrött végű pántkarperec, Kiss Attilánál kikerekedő típus szerepel. ${ }^{383}$

Kistokaj-Gerenda-dülő 4., 5., 17., 34., 45., 58., 68. és szórvány sír (Borsod-Abaúj-Zemplén m.). 4. sír: ezüstlemez karperec, a pánton váltakozóan egy, illetve kettő pontkörös poncbeütéssel. A temető egyik korai temetkezése a kísérőleletek alapján: kukoricacső alakú csüngős fülbevaló, rombikus fejú pántgyűrü, két pár gyöngykoszorús fülbevaló még szőlőfürt alakú csüngővel. 5. sír: ezüstlemez karperec, a pánton poncolt szaggatott kétsoros zeg-zug minta, az egyes háromszögekben négy-négy körponcolás. 17. sír: ezüst pántkarperec, a végei felé keskenyedik, felületén ellentétes ritmusban beponcolt háromszögekből fekvő rombuszsor minta (V. t. 9.). 34. sír: ezüst pánt, végei felé keskenyedik, a pánton poncolt kettős vonalú zeg-zug minta (V.t. 8.). 45. sír: bronz pánt, a végei felé keskenyedik, ferde sorokban három-három pontkörből alakított három sor pontkör díszíti (V. t. 10.). 58. sír: egyenletesen széles bronz pánt, rajta poncolt rovátkákból álló zeg-zug vonalú minta. 68. sír: férfi sírja, a vázon díszítetlen keskeny bronzpánt, egyenletes szélességú lemezből. A szórvány bronzpánton két sorban pontkörös poncokat láthatunk. ${ }^{384}$

Magyarhomorog-Kónya domb 11. sír (Hajdú-Bihar m.). Pödrött végú pántkarperec arany „hajkarika” rombusz alakú ingnyakdíszek társaságában. 385

Mezőtúr-Vízköz (Szolnok m.). Pödrött végủ bronz pántkarperec. ${ }^{386}$

Mezözombor-Bálványdomb 4. sír (Borsod-Abaúj-Zemplén m.). Ezüstpánt, egyik vége azonos a pánt középső részének szélességével, a másik vég keskenyedő. ${ }^{387}$

Miskolc-Reptér 4. sír (Borsod-Abaúj-Zemplén m.). Ezüstpánt karperec, a pántvégek keskenyednek, ez van bepödörve. A pánton poncolt alsó és fölső szegélyvonal között egymásba illeszkedő poncolt háromszögsorok (V. t. 7.). ${ }^{388}$

Murony-Soványhát (Békés m.). Ezüst bepödrött végủ pántkarperec. ${ }^{389}$

Nagyhalász-Kiszomborhegy 2. (4). sír (Szabolcs-Szatmár-Bereg m.). Egyenletes szélességü, 10 milliméteres ezüstpánt, négy darabra törve. 390

Nagykörü (Szolnok m.). Keskeny ezüst pánt, végei szűkülnek, gazdag női sírból. ${ }^{391}$

Nemeskosut-Remetedomb (ma: Košuty, SI). Pödrött végü, keskeny bronzlemez karperecek. ${ }^{392}$

Nyitra-Felsőköröskény 75. és 82. sirr (ma: Nitra-Horné Krškany, SI.). B. Chropovsky közöletlen ásatása. ${ }^{393}$

Orosháza-Nagy Albert tanya 2. sír (Békés m.). Bronz pántkarperec férfi lovas sírból, a jobb alkar közepéről és a bal felkarról könyök tájáról. Egyéb leletek: nyereg, tegez, ezüst „hajkarika”, Provencei Hugo és II. Lothar (931-947) ezüst denára. ${ }^{394}$

Penc (Nógrád m.). Szórvány bronz pántkarperec, bepödrött véggel. 395

Perse 101. sír (ma: Prša, Sl.). Ezüst pödrött végű pánt, szélessége 12 milliméter hét fülbevalóval, Nasr ibn Ahmed dirhemével, melyet al-Muktadir kalifa (908-932) uralkodása alatt veretett. ${ }^{396}$

Piliny (Nógrád m.). Bronz pántkarperec Nyáry Jenő gyűjteményéből, közelebbről nem ismert lelőhelyről. ${ }^{397}$

381 Révész 2008, 203, 206, 52. t., 54. t.

382 SZABÓ 1955, 124, 21. ábra, 30. t. 15.; KISS 1985, 260.

383 KÜRTı 1983, 251, 12. fénykép „"m”ábra; Kıss 1985, 260.

384 K. VÉGH 1993, 54, 5. kép, 54, 6. kép, 55, 8. kép, 56-57, 15. kép, 57, 18. kép, 58, 20. kép, 59, 22. kép, 59, 23. kép 13. Az 53. sírban Iszmail ibn

Ahmed szamanida emir (892-907) dirheme volt: K. VéGH 1993, 58.

385 DIENES 1963, 57-58; KISS 1985, 260.

386 MNM Itsz. 22/1930.4. FehÉr - ÉrY - KralovánszKY 1962, 663. tétel; KIss 1985, 260.

387 MeGAY 1963, 40-44; KovÁCS 2015, 24, 3. t. 21.

388 RÉvész 1992, 99, IV. t. 1.; KISS 1985, 260.

389 MRT 1998, 638-639, 10/IV. címszó, 4. jegyzet, 125. t. 17., MNM Itsz. 1912.16. 203.

390 JósA 1914, 183-184: Jósa sírszámozása szerint 4. sír, anyagmegjelölése bronz. Istvánovits 2003, 147, 134. t.; Kiss 1985, 261.

391 HAMPEL 1900, 661, 73. t. 1.; KISS 1985, 261.

392 CHROPOVSKY 1955, 267, V. t. 6.; KIss 1985, 260.

393 KISS 1985, 261; CHROPOVSKÝ 1978, 138; HANULIAK 1993, 113.

394 Dienes 1965, 141-142, 3. t.; KISS 1985, 261.

395 Patay 1957, 63, 13. t. 4.; Kiss 1985, 261.

396 ToČıK 1968, 39-40, 28. t. 22.; KIss 1985, 261.

397 Patay 1957, 63; Kiss 1985, 261; MNM Itsz. 44/1898-1069. 
Piliny-Sirmányhegy 5., 56., 58., 73. sír (Nógrád m.). 5. és 58. sír: ezüst pántok, rajtuk kettős vonalú, szaggatott poncolt zeg-zug minta. 56. sír: ezüst pánt, rajta befejezetlen félpalmettás inda díszítéssel. 73. sír: keskeny pánt, anyagát nem jelzik. ${ }^{398}$

Pozsonyvezekény-Első homok 1/41. sír (Vozokany, SI.). Pödrött végű ezüst pántkarperec, nagy csüngős veretek alsó tagja, préselt ruha díszítő korongok. ${ }^{399}$

Püspökladány-Eperjesvölgy 450. és 556. sír (Hajdú-Bihar m.). 450. sír: keskeny, 5 milliméter széles bronzpánt, beponcolt háromsoros széles zeg-zug vonallal. 556. sír: bronz pánt a könyöktől néhány centiméterre. ${ }^{400}$

Sárbogárd-Tringer tanya 19., 29., 64. sír (Fejér m.). 19. sír: bronz pödrött végű karperec. 29. sír: bronz pödrött végű pántkarperec. 64. sír: férfi sír, bizonytalan ékszer, a sírleírás nem szól róla, a fényképen nem egyértelmű. 401

Sárrétudvari-Hízóföld 139., 160., 220., 252. sír (Hajdú-Bihar m.). 139. sír: egyenletesen 13 milliméter széles bronz pánt. 160. sír: férfi temetkezés, kissé keskenyedő bronz pánt a bepödrés előtt. 220. sír: bronz pánt a bal csuklóra lecsúszva. 252. sír: jobb alkar közepén 17 milliméter széles ezüstpánt férfi sírban. ${ }^{402}$

Soltvadkert-Selymeserdő (Bács-Kiskun m.). Lovas sírban, pödrött végű pántkarperec anyagmegjelölés nélkül. Egyéb mellékletek: rombusz alakú ingnyakveretek, lószerszám. ${ }^{403}$

Sóshartyán-Hosszútető 30. sír (Nógrád m.). Női sírban a jobb karon 19 milliméter széles ezüstpánt, rajta rezgővonalú fekvő rombuszok sorával díszítve (V. t. 3.). Mellette hajfonatkorong pár, láncon lemezes csüngők. ${ }^{404}$

Szakony 28. sír (Győr-Moson-Sopron m.). Ezüst pánt, mellette rombikus metszetű bronzhuzal karperec, négy huzalból közbevetett filigránhuzalokkal csavart nyakperec, S végü hajkarika: egy bronz és egy ezüst, mindkettő kisméretü. ${ }^{405}$

Szeged-Bojárhalom 3. sír (Csongrád m.). Ezüst bepödrött végű pántkarperec a leggazdagabb női sírból. ${ }^{406}$

Szeged-Öthalom, V. homokbánya 150. sír (Csongrád m.). Bronzlemezből kivágott, keskeny pántok, egyiken a bepödrés előtt ütött lyuk (V.t. 6.). ${ }^{407}$

Szentes-Borbásföld 12. sír (Csongrád m.). Két ezüst pántkarperec, töredékben, rombusz alakú ingnyak díszek, préselt korongok mellett..408

Szentes-Nagyhegy, Bogyó Jánosné telke (Csongrád m.). Két lemezkarperec Bálint szerint bepödrött végekkel. ${ }^{409}$

Szentes-Kökényzug-Jaksor, Molnár Ignác földje (Csongrád m.). A lelőhely azonos a KunszentmártonKökényzug-Jaksor lelőhellyel (Szolnok m.). Töredék pántkarperec, bronz lemez, bepödrött véggel. ${ }^{410}$

Szentes-Nagyhegy, Gyarmati Sándor szőlője (Csongrád m.). Pödrött végű bronz pántkarperec.411

Szentes-Szentlászló 82. sír (Csongrád m.). Ezüst pántkarperec pár, pödrött végekkel, mindkét alkaron. ${ }^{412}$

Szob-Kiserdő 14. és 66. sír (Pest m.). 14. sír: bronz pántkarperec bepödrött végekkel, a pántot $V$ alakban elrendezett, finoman bekarcolt rovátkák díszítették, hasonló rovátkolt keretben. Ez a díszítés azonos az előzőekben többször említett poncolt zeg-zug mintával, amely poncolt szegélydíszítő keret között húzódott. A fényképes táblán élére fektetve a minta nem látszik. 66. sír: bronz lemezkarperec, a pántvégek elkeskenyedve lekerekítettek és visszahajlítottak, illetve az egyik pántvég kissé meg van pödörve. ${ }^{413}$

Szolnok-Szanda, Beke Pál halma, III. temető 4. sír (Szolnok m.). Bronz pánt, a pántvégek felé majdnem felére keskenyedik és ez a rész van bepödörve (V. t. 4.). ${ }^{414}$

Szőreg-Homokbánya A sír (Csongrád m.). Bronz pánt fele jelentősen leszűkülő pántvéggel, amelyet bepödörtek. A pánton poncolt kettős vonalú zeg-zug minta, amely a szögleteken kissé lekerekített, és így hullámvonalnak is hat. A háromszögek csúcsaiban kisebb kettős vonalú V mintákat poncoltak (V. t. 5.). A pánttöredék két

398 NYÁRY 1902, 210-240; HAMPEL 1907, 178, 65. t., 181, 67. t., 181, 68. t., 183, 70. t.; KISS 1985, 261.

399 TočIK 1968, 63, 54. t. 8.; KISS 1985, 264.

400 NepPER 2002, 193, 206. t., 204, 216. t.

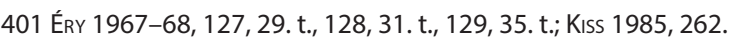

402 NePPER 2002, 326, 282. t., 329, 289. t., 343, 319. t., 348, 328. t.

403 BÁLINT 1991, 247-248, no. 222.; KISS 1985, 262.

404 Fodor 1973, 34, 5. kép 1.; Kıss 1985, 262.

405 GÖMÖRI 1984, 89, 9. kép

406 Reizner 1891, 101; Hampel 1900, 686, 83. t. 3.; LÁszló 1944, 152, XV. t.; KIss 1985, 262.

407 TÜRK - LÖRINCZY 2015, 32, 97. kép 2, 104. kép

408 RévÉSz 1996b, 301, 10. kép 28.; Kıss 1985, 263.

409 BÁlint 1991, no. 283.; FehÉr - Éry - KRALovÁnsZKY 1962, 1019. tétel; KIsS 1985. nem említi.

410 BENDE - LÖRINCZY 1997, 228, 26. kép 12.; KISS 1985, 260.

411 Csallány 1905, 39-40; Fehér - ÉRy - Kralovánszky 1962, 1020. tétel; Kiss 1985, 263.

412 SzÉLL 1941, 241, VII. t. A. 15, 19.

413 ВАКАY 1978, 14, 3. t. 16., 34, 19. t. 27. Mivel a leletkataszter címszavában nem említik a karpereceket, ezért Kiss Attila lelőhelylistájáról is

hiányoznak.

414 Madaras 2006, 220, 243, 6. kép 4. 
darabból van aklaszeggel összefogva. A sírban szív alakú csörgős veret, bronzlemez hajfonatkorong, sodrott bronz karperec is volt. ${ }^{415}$

Tiszabercel-Ráctemető 4. sír (Szabolcs-Szatmár-Bereg m.). A jobb alkaron pödrött végű bronz pántkarperec, mellette két hajfonatkorong, csüngős veretek rombikus felső taggal. ${ }^{416}$

Tiszabercel-Újsor 8. sír (Szabolcs-Szatmár-Bereg m.). A váz jobb karján 15 milliméter széles, pödrött végú pántkarperec. Anyagát nem említik, elveszett, rajz sem maradt róla. 417

Tiszadob-Sós-szék 5. sír (Szabolcs-Szatmár-Bereg m.). Két darab pödrött végú ezüst pántkarperec, a sírleírás szerint mindkettő a jobb kézen, a csukló felett, a sírrajz szerint mindkét kézen egy-egy karperec a csuklók felett. ${ }^{418}$

Tiszaeszlár-Vörösmarty u. 3. sír (Szabolcs-Szatmár-Bereg m.). Női sírból ezüst pántkarperec pödrött véggel. A rajzos táblán az eredeti közlemény semmitmondó fényképét rajzolták át. ${ }^{419}$

Tiszajenő-Eperjesi telep 4. sír (Szolnok m.). A sír két karperece közül az egyik pödrött végú és ezüst. ${ }^{420}$

Tornóc 330. sír (Trnovec nad Vahom, Sl.). Ezüst pántkarperec pödrött végekkel, pántszélesség nincs megadva. A női sírban egy pár sokkosaras ezüst fülbevaló mellett két pár gyöngykoszorúval és granulált szőlőfürtös csüngővel díszített fülbevaló is volt. ${ }^{421}$

Üllö-llona út 7. sír (Pest m.). Bronz pántkarperec, egyik vége letörött, a másik ép és bepödrött. ${ }^{422}$

Valkóvár 211. sír (ma: Vukovar-Lijeva-Bara, Hrv.). Keskeny bronzpánt egyenesen levágott és bepödrött végekkel (V. t. 2.). Mellette lépcsős fejü, pontkörös díszű gyűrü, kerek metszetű bronz huzalkarperec volt. ${ }^{423}$

Vágvörösvár 8. sír (ma: Červenik, Sl.). Női sírban bronz bepödrött végủ pántkarperec, keskeny, egyenletesen 7 milliméter széles lemezből, egyik vége letörött, mellette négy csüngős veret, csizmaveretek. ${ }^{424}$

Várpalota-Semmelweis u., 1. és 11. sír (Veszprém m.). 1. sír: ezüst vagy ónozott bronz pödrött végű pántkarperec, ezüstlánc és szív alakú csüngős veretek párta-veretekkel. 11. sír: ónozott bronz pántkarperec mindkét alkaron, végei keskenyednek. ${ }^{425}$

Vörs-Majori-dülö (Somogy m.). Előzetes jelentés díszítetlen, pödrött végű bronz pántkarperecről, sírszám és illusztráció nélkül.426

Vörs-Papkert „B" 406. sír (Somogy m.). Előzetes jelentés illusztrációjában bemutatott bepödrött végű pántkarperecek. ${ }^{427}$

Zsitvabesenyő-Sírdülő 30. és 107. sír (ma: Bešenov, SI.). 30. sír: pödrött végü bronz pántkarperecek, az egyiken páros, szaggatott vonalú poncolt zeg-zug mintalátható (V. t. 1.), a párja díszítetlen. 107. sír: egyenletes szélességú bronz pántkarperec, a pántvégek alig keskenyedve bepödröttek. A pánton alul és felül poncolt karikasor látszik. ${ }^{428}$

\section{Bandarmreifen der ungarischen Landnahmezeit}

\section{KÁROLY MESTERHÁZY}

Der Verfasser untersucht drei Haupttypen der Bandarmreifen. In dessen Interesse versuchte er all ihre Fundorte und Exemplare zu sammeln. Die Grundsuche wurde bereits vor 40 Jahren von Attila Kiss gemacht. Zu der Zeit betrug die Gesamtzahl der drei Typen etwa 190, heute ungefähr 240. Die Unsicherheit wird durch den unveröffentlichten Stücken verursacht. Die wichtigsten Daten wurden 1962 von Béla Szőke zusammengefasst und seine Feststellungen müssen in vielerlei Hinsicht ergänzt werden.

1. Einfache Blecharmreifen mit rundlich verbreiterten Enden. Das Band eines Teiles von ihnen verbreitet sich tatsächlich, die Bandbreite des anderen Teiles verändert sich nicht, das Ende des Bandes wird nur abgerundet. Beide Hauptformen haben weitere Variationen, z.B. ist das sich verbreitende Band in der Mitte geteilt und schließt sich mit zwei Halbkreisen. Sie sind aus silbernen oder bronzenen Blech gefertigt, aber es gibt Vergoldung und

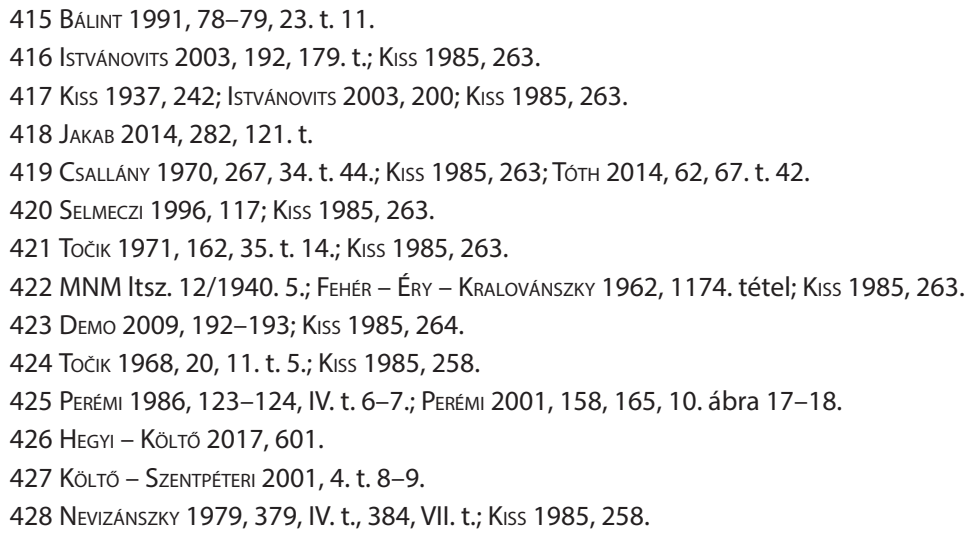


Bedeckung mit Gold. (Heves). Diese Art kommt fast ausschließlich in dem archäologischen Kreis vor, in dem die vornehmen Frauen ein rosettenverziertes Pferdegeschirr haben. Die Friedhöfe in Karos gehören zu diesem Kreis, und nur zwei der 23 Armbänder gehören zu anderen Arten. Sie sind in entscheidender Mehrheit Schmuckstücke der Frauengräber, aber dies ist auch nicht selten bei vornehmen Männern (Vereb, Hajduböszörmény-Vid, AradCsálya, usw.). An den schönsten Stücken ist eine Palmettenranke zu sehen (Mezőzombor, Fehéregyháza). An fast ein Dutzend Armbandpaaren ist an den Enden des Bandes eine Silberauflage mit Glaspasteneinlage zu sehen. Die Auflage ist entweder mit Löten oder mit Nietnagel befestigt. Meistens werden je 2 Niete verwendet, es gibt aber auch eine Befestigungsweise mit je 3 Niete. Manchmal ist die Auflage runtergefallen, dann verraten uns das nur noch die Nietlöcher. Bei fast 30 Armbändern jedoch gibt es nur je 1 Nietloch am Ende des Bandes. Ihre Beurteilung ist noch umstritten. Vielleicht waren sie an der Manschette angenäht, andere denken, dass das Armband und darunter der bauschige Ärmel, den sie für weit geschnitten hielten (siehe ungarische Tschikosgewand) mit dem in diese Löcher genähten Faden zusammengepresst wurden. Sie erscheinen zur Zeit der Landnahme im Karpatenbecken und kommen schon in den frühesten Gräbern vor, unter ihnen mit westlichen Denaren oder mit arabischen Dirhams datiert (Vereb, Sárospatak-Baksa-homok). Aber da die typischste Variante vom Dnjepr-Gebiet noch nicht aufgetaucht ist, werden sie von mehreren für später datiert. Ihre zahlreiche Varianten haben aber auch da eine Analogie (Korobčino, Subbotici), deswegen ist es nach der Ansicht des Autors nur noch eine Frage der Zeit, wann die fehlenden Parallelen dort auftauchen. In den Kurganen in Kostroma 250 km von Moskau entfernt kommen alle ungarischen Typen schon im 11. Jahrhundert vor. Dieser Typ ist im Karpatenbecken langlebig. Aber die späteren Varianten werden schon aus Bronzeblech hergestellt und sind mit Augenkreis/Punktkreis verziert. Diese Variante ist ab dem letzten Viertel des 10. Jahrhunderts üblich und erscheint auch mit der Münze vom König András (1046-1060) (Gyulafehérvár/ Alba lulia). Auch diese Verzierung hat mehrere Varianten, z.B. reihen sich die Augenkreise in ein, zwei oder drei Reihen am Band des Armreifens, usw. In Serbien wurden sie auch noch im 14. Jahrhundert verwendet.

2. Blecharmbänder mit eingerollten Enden. Sie kamen von etwa 80 Fundorten zum Vorschein, in einem Verhältnis von 50 zu 50 Prozent wurden sie aus Silber und aus Bronze hergestellt. Sie kennzeichnen die Gruppe der Landnahmezeit, in der die Frauenbekleidung auffallend reich war (in der anderen Gruppe war das Pferdegeschirr reich!) und der zweiteilige Silberanhänger das entscheidende Element ist. Die Bänder werden oft mit einem punzierten Zickzackmuster verziert, manchmal kommt auch eine Ranke vor. In einigen Gräberfeldern sind sie ungewöhnlich häufig (Kistokaj), anderswo kommen sie gar nicht vor (Halimba, Győr, Majs), und das hat nicht nur einen chronologischen Grund. Wahrscheinlich taucht dieser Typ während der Landnahme im Karpatenbecken auf und wir treffen sie auch am Anfang des 11. Jahrhunderts auf, obwohl sie mit ungarischen Münzen nicht erschienen. Auch dieserTyp ist für Frauengräber charakteristisch, wir kennen ihn aber ausnahmsweise aus einigem Männergrab. Man sagt, sie kommen von Gräberfeldern des Gemeinvolkes zum Vorschein, was auch wahr ist, aber aus den reicheren Gräbern. Sie waren also nicht Schmuckstücke des Gemeinvolkes sondern die der Mittelschicht.

3. Scharnierarmreifen. Der meist verzierte Typ der Bandarmreifen. Es gibt eine Variante mit einem Scharnier versehen, und eine andere Variante mit einem aus zwei Halbbändern gefertigten Doppelscharnier. Dies sind wahrscheinlich Nachahmungen byzantinischer Armreifen oder echte Importstücke. Der silberne Armreifen aus Szarvas ist mit einem Scharnier versehen. Am Band, vom dem heute 4 Bruchstücke vorhanden sind, standen fünf Greifen im Rundell sich gegenüber bzw. einander den Rücken zugedreht. Das letzte Rundell, da es am Band des Armreifens nicht mehr nötig war, wurde am Beginn abgeschnitten. Der silberne Armreifen aus Tiszaeszlár war mit zwei Scharnieren und mit drei Medallionen an einem Halbband versehen, an jedem Band werden je eine Palmette von zwei perlhuhnähnlichen Vögeln in die Mitte genommen. Diese sind aufgrund ihrer Parallelen fremdartige Typen, aber ihre Herstellungstechnik ist gleich mit der ungarischen Blecharbeit, alle Linien sind punziert, Hintergrund zurückhämmert, feuervergoldet. Der Armreifen aus Ártánd wurde aus Bronze gegossen, vergoldet, derzeit noch ohne Parallele.

4. Die goldenen aber zumeist silbernen Bänder, Schleifen, die am Handgelenk gefunden wurden, dienten zur Verzierung der Totenbekleidung und hatten an beiden Enden Löcher zur Befestigung. Sie können 15-20 cm lang sein, sie haben sich damals komplett um das Handgelenk gewickelt. Ein andermal wurden je zwei Stücke benutzt, es wurden für diesen Zweck sogar vier kleinere Bänder verwendet (Orosháza). Diese Bänder wurden an den Manschetten des Totenhemdes oder an die des Kaftans angenäht, aber sie konnten auch am Rande anderer Kleidungsstücke angenäht werden. 

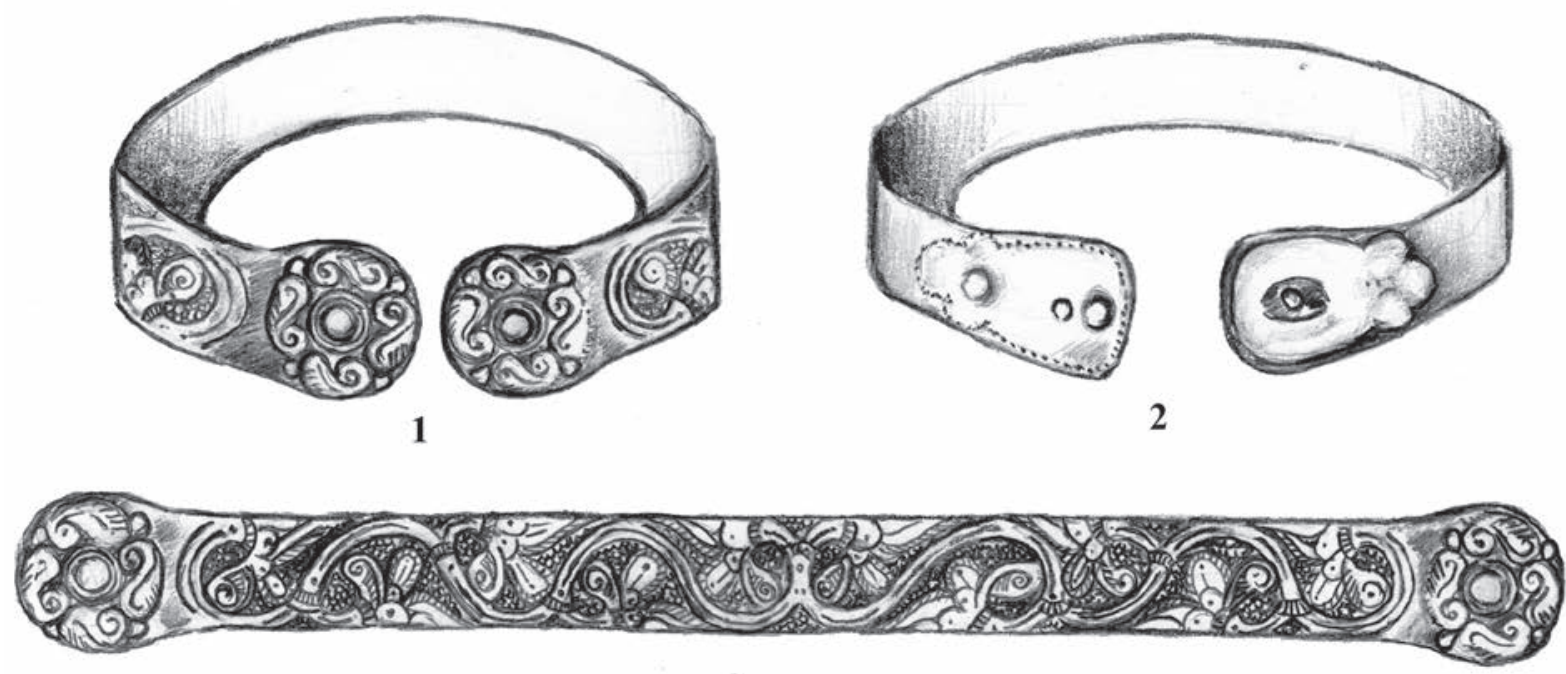

3

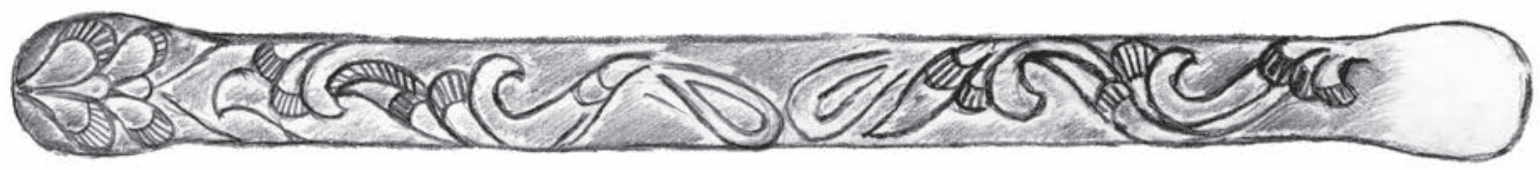

4

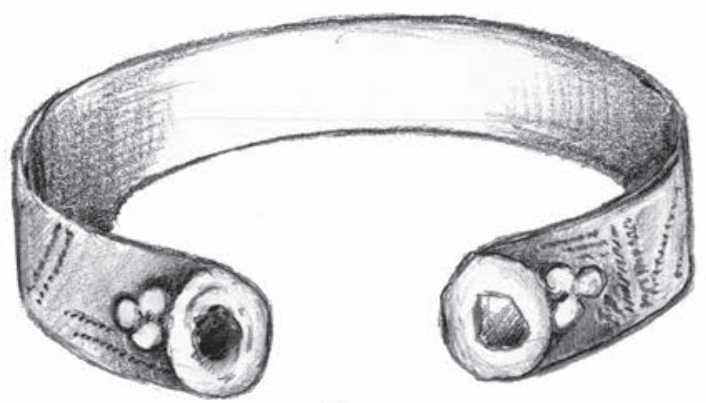

5

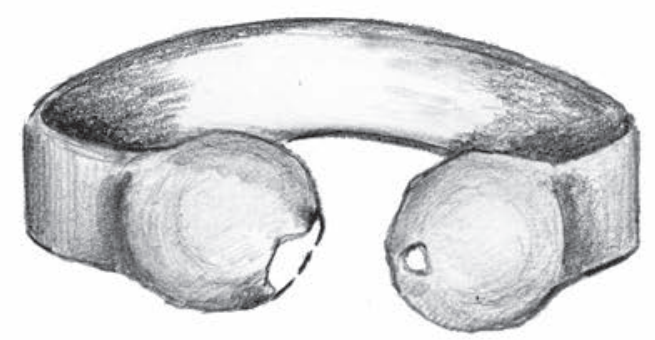

6

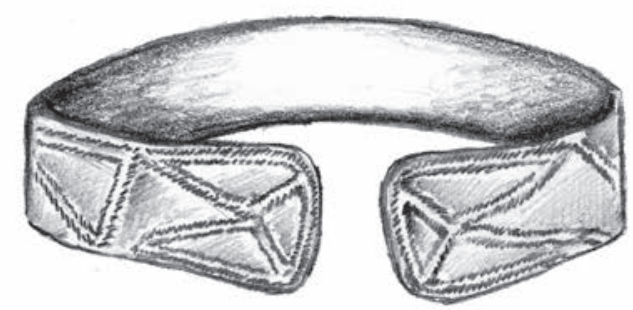

7

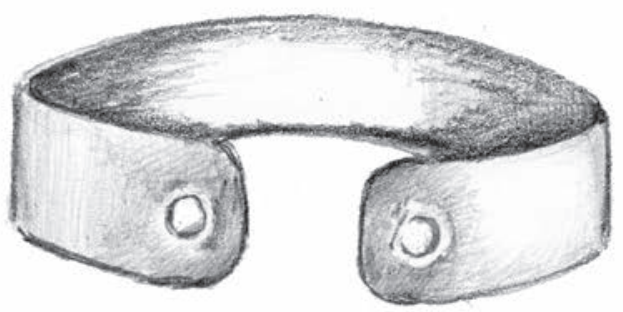

8

I. tábla. Ki-és lekerekedő végü pántkarperecek. 1, 3:Mezőzombor; 2: Madaras; 4: Kiskunfélegyháza-Ferencszállás; 5: Nagykáta; 6: Oroszlámos; 7: Sajólád; 8: Sárrétudvari-Hízóföld 167. sír 

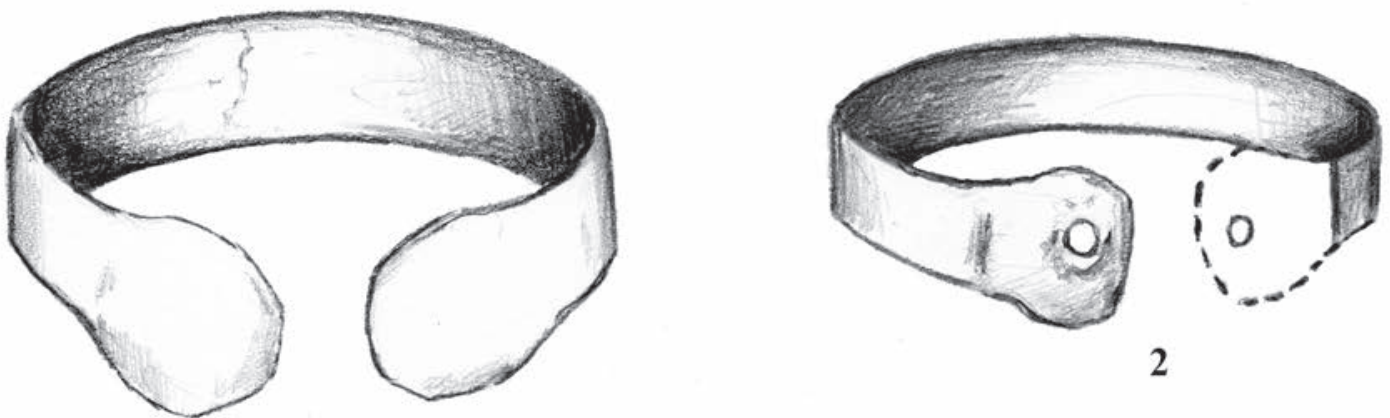

2

1
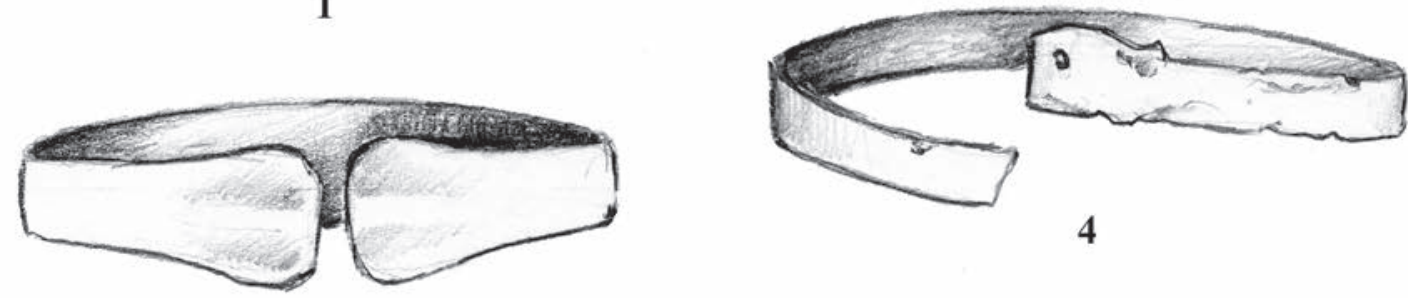

4

3

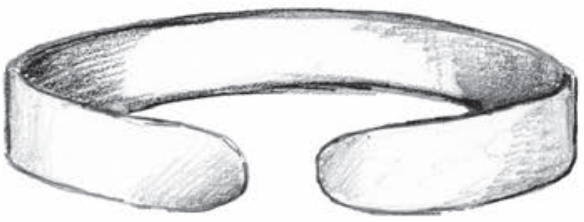

5

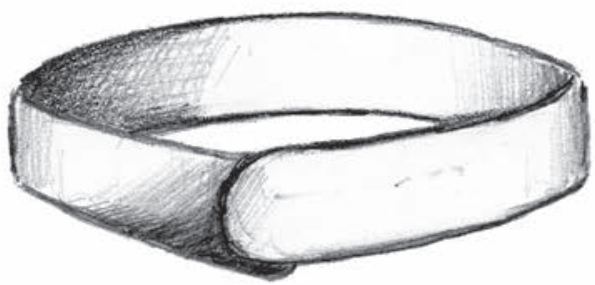

6
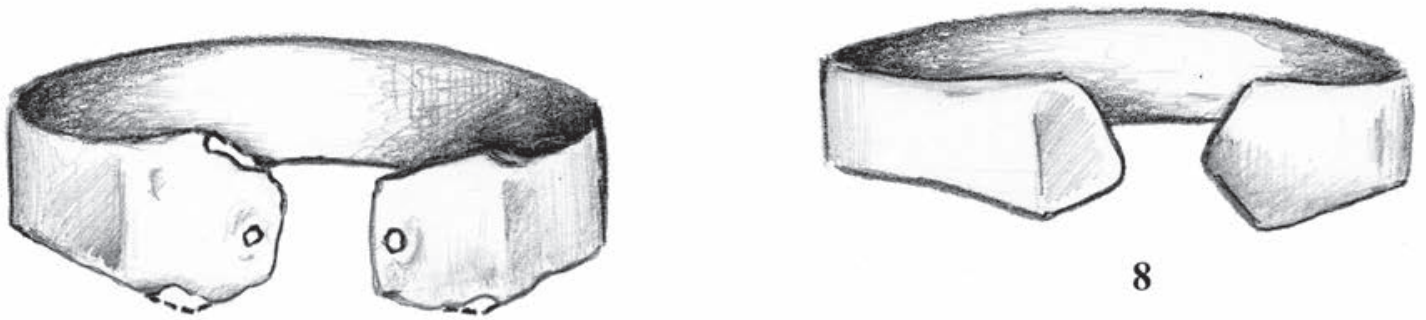

8

7

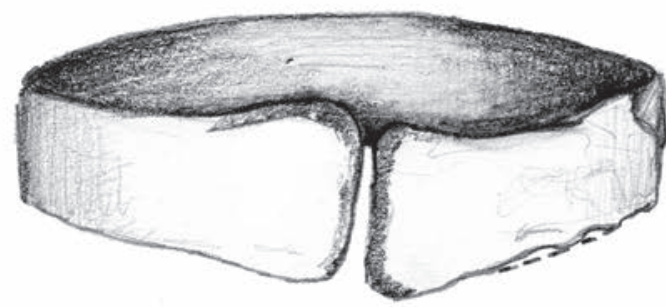

10

II. tábla. Ki-és lekerekedő végü pántkarperecek. 1: Nagyszokoly; 2: „Galgóc”; 3: Gáva, 4: Geszteréd; 5: Szered 5/54. sír; 6: Zalkod; 7: Gyulavarsánd; 8: Szakony; 9: Sárrétudvari-Hízóföld 33. sír; 10: Sajtény 


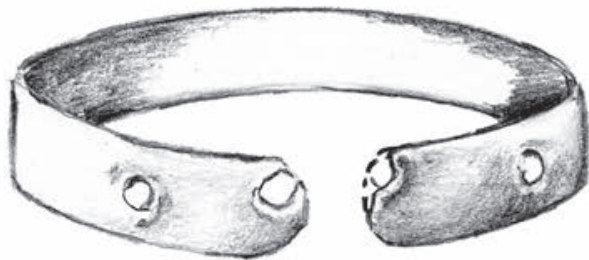

1

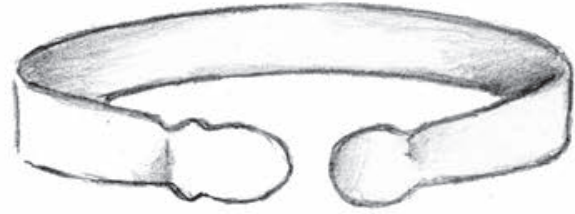

3

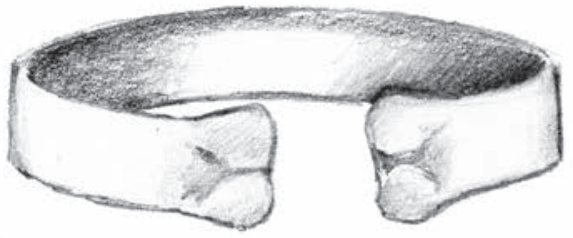

5

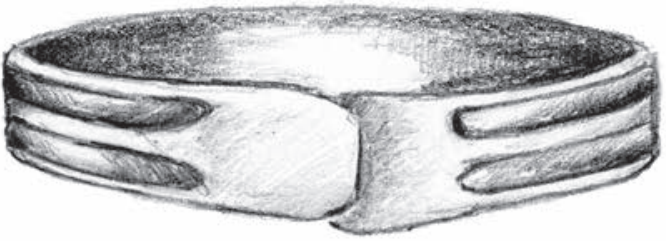

7

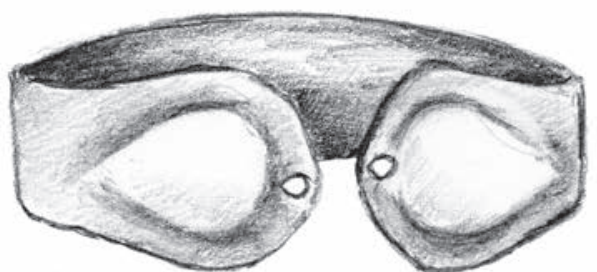

9

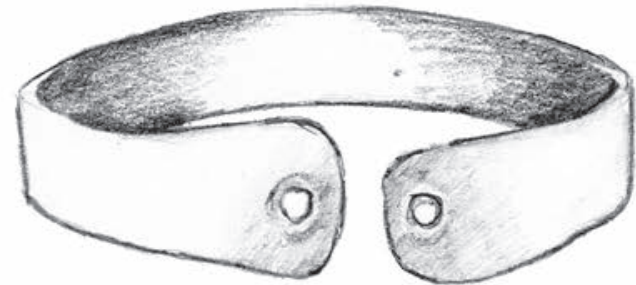

2
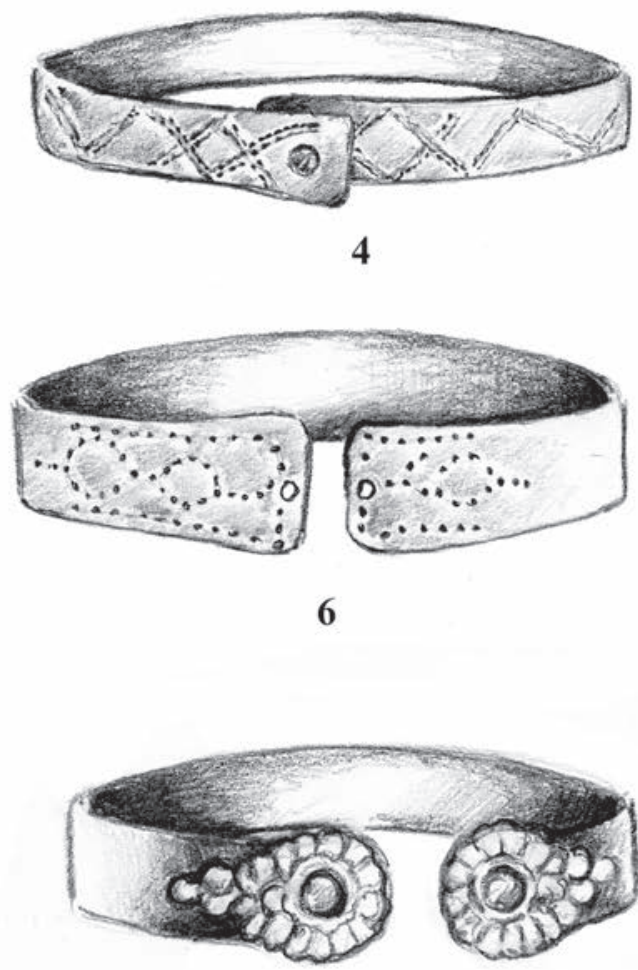

8

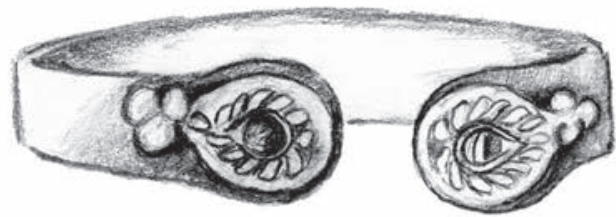

10

III. tábla. Ki-és lekerekedö végü pántkarperecek. 1: Bánkeszi 23. sír; 2: Biharkeresztes-Bethlen G. út; 3: Budapest-Soroksár; 4: Csekej 401. sír; 5: Galánta; 6: Hertelendyfalva; 7: Györ-Újszállások; 8: Egyek; 9: Ibrány-Esbóhalom; 10: Kistokaj 

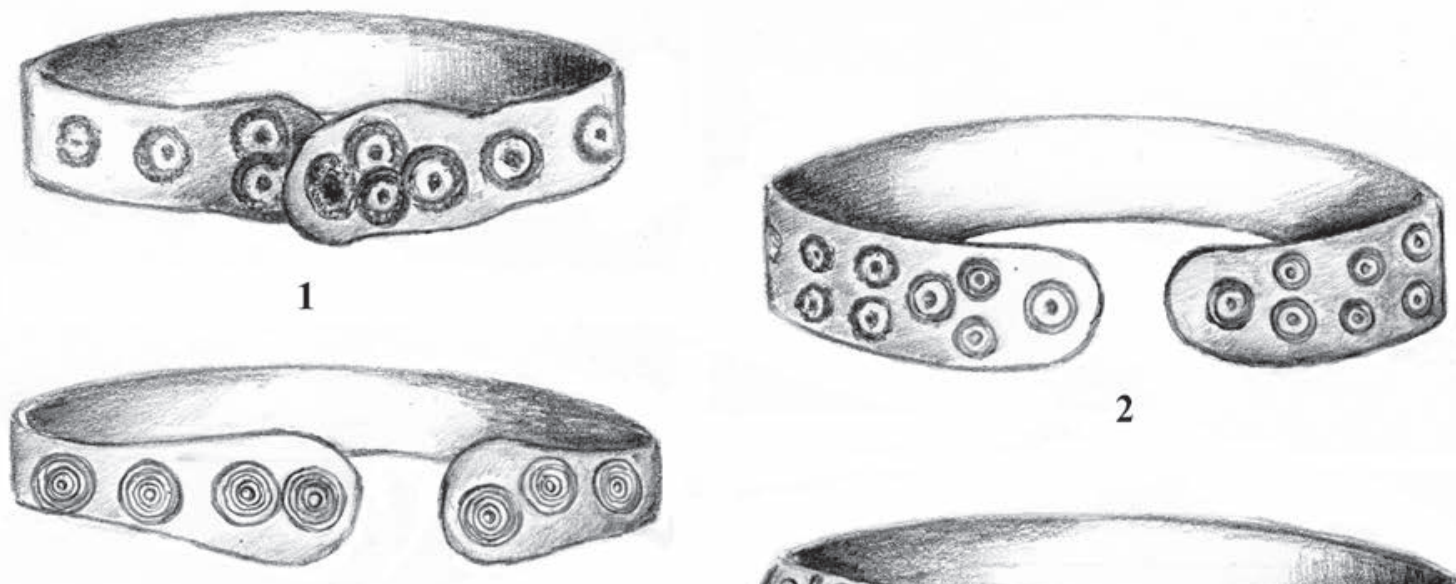

2
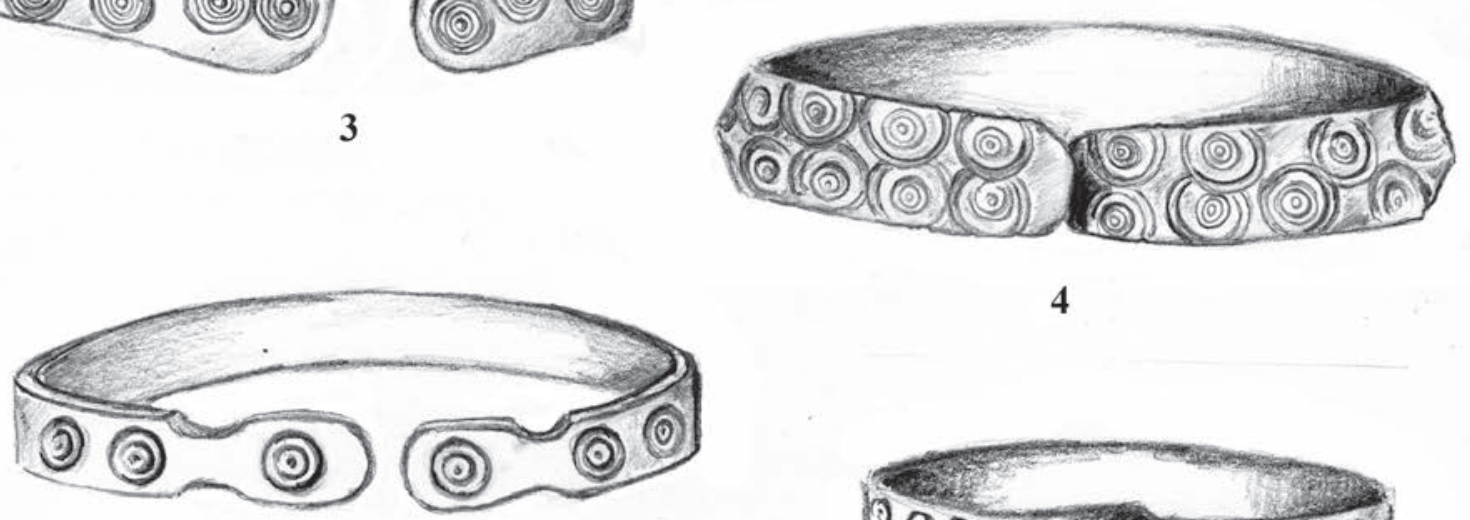

4

5

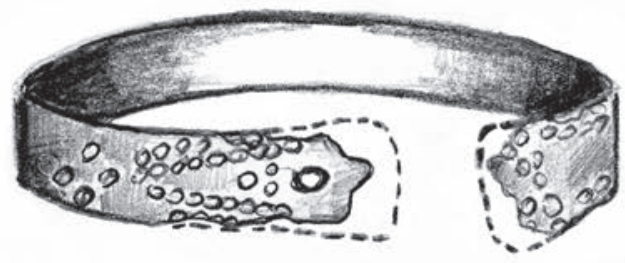

7

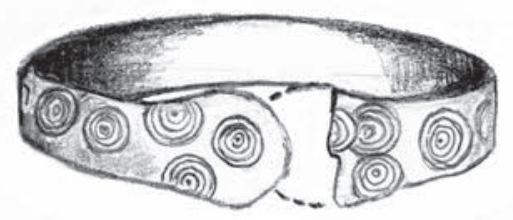

8
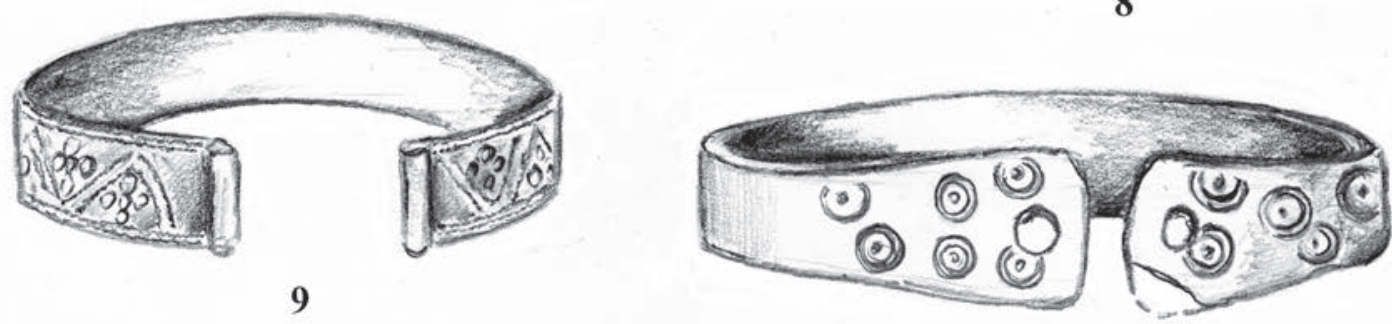

10

IV. tábla. Pontkörös díszitésü pántkarperecek. 1: Fábiánsebestyén; 2: Nádudvar-Töröklaponyag; 3: Püspökladány-Eperjes; 4: Körösszegapáti; 5: Mezökovácsháza; 6: Letkés II/67. sir; 7: Homokmégy-Székes; 8: Csölle; 9: Kistokaj; 10: Várfalva 42. sír 


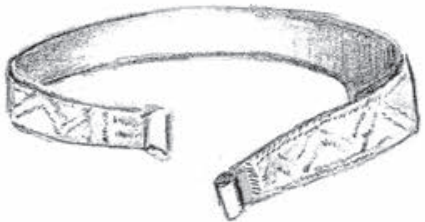

1

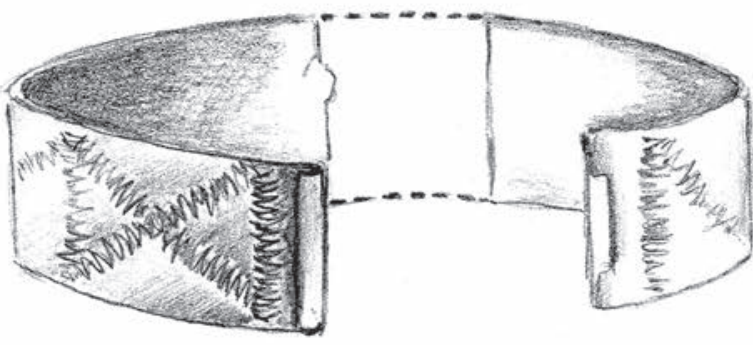

3

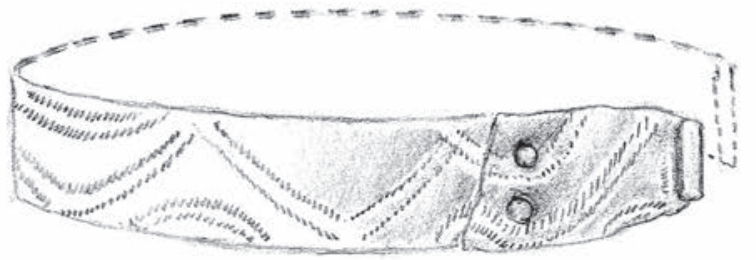

5

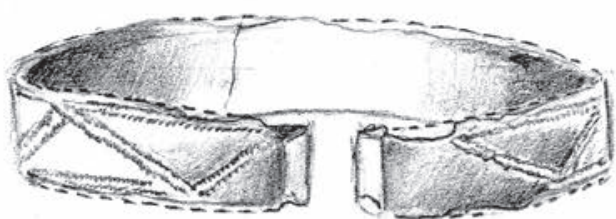

7

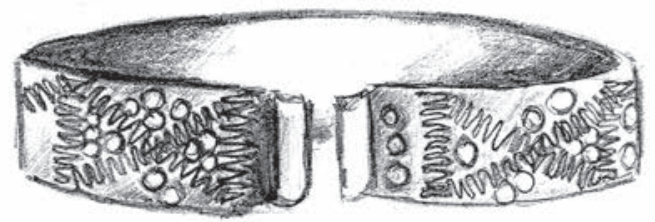

9

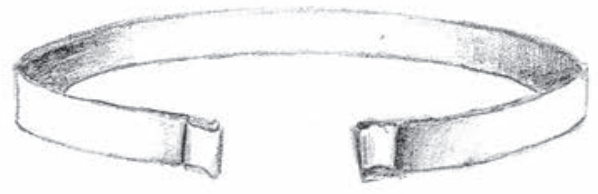

2

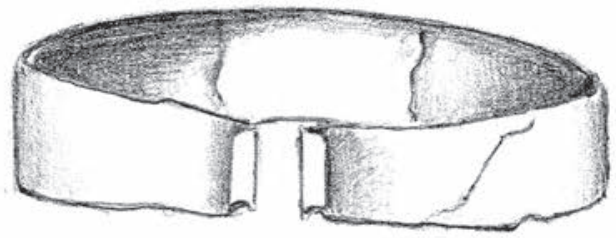

4

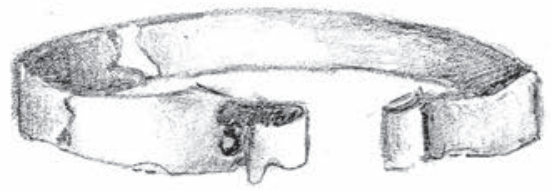

6

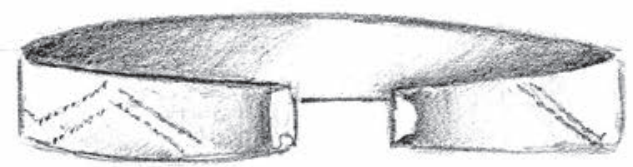

8

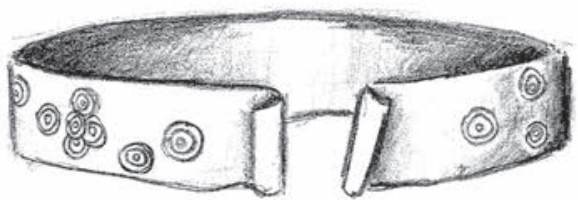

10

V. tábla. Pödrött végü pántkarperecek. 1:Zsitvabesenyő; 2: Valkóvár; 3: Sóshartyán; 4: Szolnok-Szanda; 5: Szöreg; 6: Szeged-Öthalom 150. sirr; 7: Miskolc-Repülötér; 8: Kistokaj 34. sír; 9: Kistokaj 17. sír; 10: Kistokaj 45. sír 


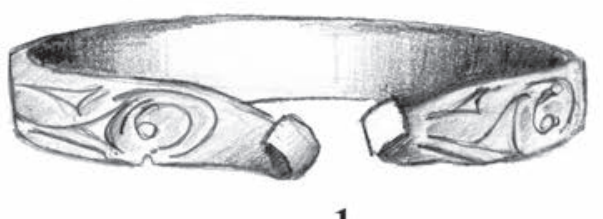

1

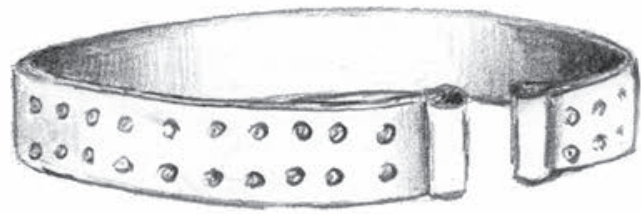

3

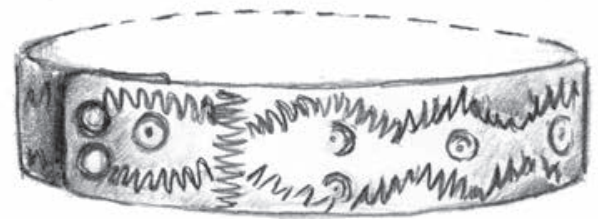

5

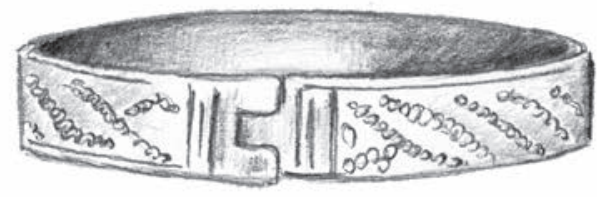

7

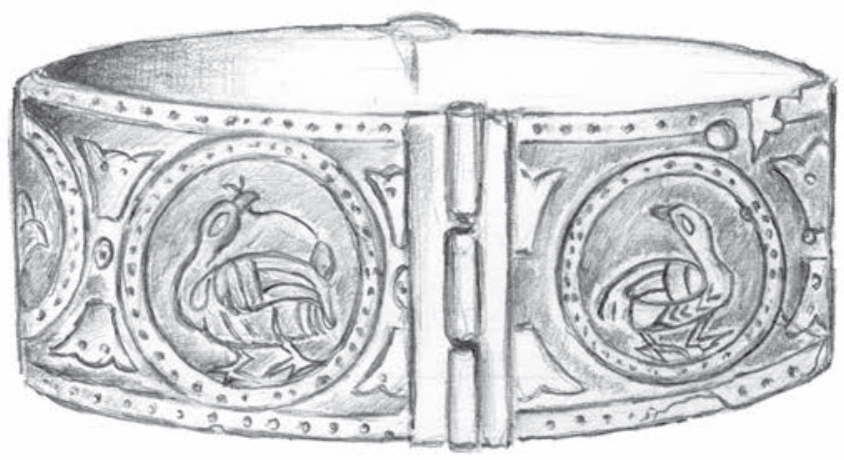

9

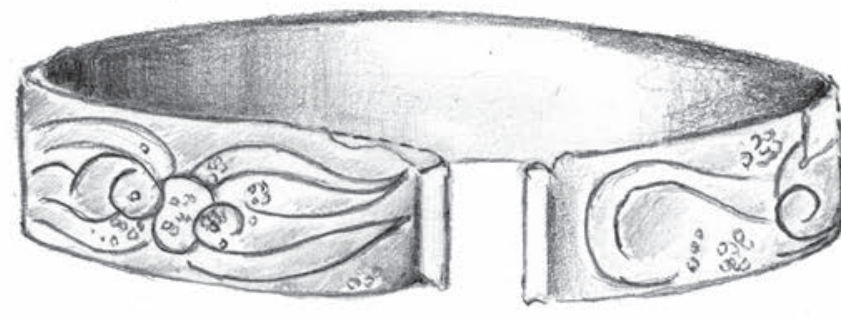

2

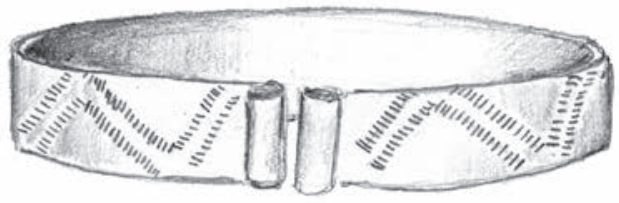

4

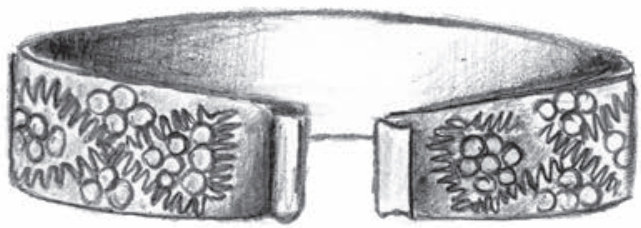

6

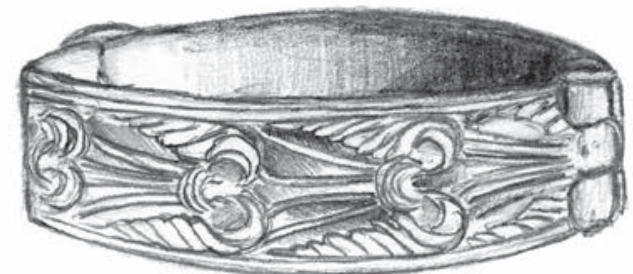

8

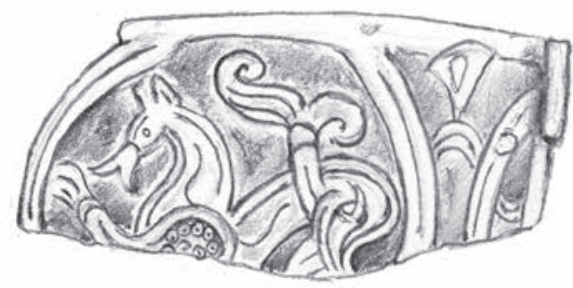

10

VI. tábla 1-6: Pödrött végü pántkarperecek. 1: Kecskemét-Lakihegy; 2: Génye; 3: Galánta; 4: Ipolykiskeszi; 5: Csekej 336. sír; 6: Biharkeresztes-Bethlen G. út; 7-10: Csuklós pántkarperecek; 7: Hajdúszoboszló-Árkoshalom 77. sír;

8: Ártánd-Nagyfarkasdomb; 9: Tiszaeszlár-Bashalom; 10: Szarvas 


\section{Irodalom}

Aцıмвау 2009 Alimbay, Nursan (ed.): Kazaktyn desturli riim-kesegi. Традиционная одежда казаков. Kazakh traditional garments. Almati, 2009.

AlmÁsSY - IstVÁNOvits - KuRUCZ 1997 Almássy Katalin - Istvánovits Eszter - Kurucz Katalin (szerk.): Aranyak a Jósa András Múzeumban. Nyíregyháza, 1997.

BAJALOVIĆ-BIRTAŠEVIĆ 1960 Бајаловиђ-Бирташевиђ, Марија: Средњевековна некропола у Миријеву (La necropole medievale dans le village de Mirievo). Beograd, 1960.

BAKAY 1965-66 Bakay Kornél: Gräberfelder aus dem 10-11. Jahrhunderten in der Umgebung von Székesfehérvár und die Frage der fürstlichen Residenz. Alba Regia 6-7. 43-88.

BAKAY 1978 Bakay Kornél: Honfoglalás- és államalapítás kori temetők az Ipoly mentén. Studia Comitatensia 6. Szentendre, 1978.

BALOGH 1938 Balogh Albin: Mindennapi élet Szent István korában. In: Serédi Jusztinián (szerk.): Emlékkönyv Szent István király halálának kilencszázadik évfordulóján. III. Budapest, 1938. 561-594.

BÁLINT 1932 Bálint Alajos: Honfoglaláskori sírok Ószentivánon és Bánkútom (Gräber aus der Landnahmezeit zu Ószentiván und Bánkút). Dolgozatok 19. 256-264.

BÁLINT 1968 Bálint Csanád: Honfoglalás kori sírok Szeged-Öthalmon. A Móra Ferenc Múzeum Évkönyve 1968. 47-88.

BÁLINT 1971 Bálint Csanád: X. századi temető a szabadkígyósi-pálligeti táblában (Tenth century cemetery in the Pál liget plot of Szabadkígyós). Békés Megyei Múzeumok Közleményei 1. 49-88.

BÁLINT 1991 Bálint, Csanád: Südungarn im 10. Jahrhundert. Budapest, 1991.

BANNER 1943 Banner Benedek: Honfoglaláskori sír Mezőmegyeren (Ein Grab aus der Landnahmezeit in Mezőmegyer). Dolgozatok 19. 172-175.

BeLLA 1895 Bella Lajos: Újabb csornai leletekről. Archaeologiai Értesítő 15. 253-256.

BenCZE - SzIGetı 2015 Bencze Zoltán - Szigeti Judit: A pesti síkság honfoglalás és kora Árpád-kori temetői (Soroksár, Pesterzsébet, Kispest-Szentlőrinc és a Csepel-sziget) (Cemeteries from the Hungarian conquest and Arpadian Ages ont he Pest Plains). Budapest Régiségei 48. 95-130.

BENDE - LóRINCzy 1997 Bende Lívia - Lőrinczy Gábor: A szegvár-oromdűlői 10-11. századi temető (Das Gräberfeld von Szegvár-Oromdűlő aus dem 10. bis 11. Jahrhundert). A Móra Ferenc Múzeum Évkönyve - Studia Archaeologica 3. 201-285.

BoкIJ - Pletnyova 1988 Бокий, Н. М - Плетнева, С. А.: Захоронение семьи воина-кочевника Х. в. в Бассейне Ингула. Советская Археология 1988/2. 99-115.

Bolıók 2015 Bollók Ádám: Ornamentika a 10. századi Kárpát-medencében. Formatörténeti tanulmányok a magyar honfoglalás kori díszítőmüvészethez. Budapest, 2015.

BónA 1971 Bóna István: Honfoglaláskori magyar sír Dunaújvárosban (Une tombe de l'époque de la conquete hongroise a Dunaújváros). Archaeologiai Értesítő 98. 170-174.

Bosselmann-RuickBIE 2011 Bosselmann-Ruickbie, Antje: Byzantinischer Schmuck des 9. bis frühen 13. Jahrhundert. Untersuchungen zum metallenen dekkorativen Körperschmuck der mittelbyzantinischen Zeit anhand datierten Funde. In: Spätantike. frühes Christentum, Byzanz. Reihe B: Studien und Perspektiven 28. Wiesbaden, 2011.

BÖRZsÖNYI 1912 Börzsönyi Arnold: Gyömörei sírlelet a honfoglalás korából. Archaeologiai Értesítő 32. 214-219.

ChIDIOSAn 1965 Chidiosan Nicolae: Mormintul din perioada feudalismului timpuriu de la Galospetreu (Raion Marghita). Studii si Comunicari 12. 237-243.

CHROPOvský 1955 Chropovský, Bohuslav: Výskum staromad'arského pohrebište v Košutoch, okr. Galanta. Slovenská archeológia 3. 264-275.

CHROPOvský 1978 Chropovský, Bohuslav: Nitra, čast Horné Krškany. In: Chropovský, Bohuslav (ed.): Vyznamne slovanské náleziska na Slovensku. Bratislava, 1978. 138-142.

Ciugudeanu - Pinter - Rustolu 2006 Ciugudeanu, Horia - Pinter, Karl Zeno - Rustoiu, T. Gabriel: Habitat-religie-etnicitate: Descoperiri archeologice din secolele IX-XI in Transilvania. Catalog de expoziţie. Alba lulia, 2006.

CSALLÁny 1899 Csallány Gábor: Római kori temetőről Öcsöd és Szt.András határában. Archaeologiai Értesítő 19. 41-44.

CSALLÁNY 1905 Csallány Gábor: Régi magyar emlékek a szentesi múzeumban. Archaeologiai Értesítő 25. 33-44.

CSAlLány 1941 Csallány Gábor: Újabb honfoglaláskori leletek Szentes környékéről (Neuere Funde der ungarischen Landnahmezeit aus der Umgebung von Szentes). Folia Archaeologica 3-4. 182-192.

Csallány 1959 Csallány, Dezső: Ungarische Zierscheiben aus dem X. Jahrhundert. Acta Archaeologica Hungaricae 10. 281-325. 
Csallány 1970 Csallány, Dezső: Weiblicher Haarflechteschmuck und Stiefelbeschläge aus der ungarischen Landnahmezeit im Karpatenbecken. Acta Archaeologica Hungaricae 22. 261-299.

CsÉplő 1897 Cséplő Péter: A csökmői és puszta kovácsi leletekről. Archaeologiai Értesítő 17. 437-441.

CZIRÁky 1900 Cziráky Gyula: Bogojeva régi emlékeiről. Archaeologiai Értesítő 20. 265-267.

Dемо 2009 Demo, Željko: Rannosrednjovjekovno groblje bjelobrdske kulture : Vukovar-Lijeva Bara (X-XI. stoljeće) - An Early Medieval Cemetery of the Bijelo Brdo Culture: Vukovar-Lijeva Bara $\left(10^{\text {th }}-11^{\text {th }}\right.$ Centuries). Zagreb, 2009.

DienEs 1963 Dienes István: Magyarhomorog-Kónyadomb. Régészeti Füzetek Ser. 1/16. 57-58.

DIENES 1964 Dienes István: A karancslapujtői honfoglalás kori öv és mordvinföldi hasonmása (La ceinture de Karancslapujtő de l'époque de la conquete hongroise et son pendant provenant du pays des Mordves). Archaeologiai Értesítö 91. 19-40.

DienES 1965 Dienes István: A honfoglaló magyarok. In: Nagy Gyula (szerk.): Orosháza története és néprajza. Orosháza, 1965. 136-174.

DienEs 1972 Dienes István: A honfoglaló magyarok. Budapest, 1972.

DienEs 1986 Dienes István: A Felső-Tisza-vidék a X. században. In: Entz Géza (szerk.): Szabolcs-Szatmár megye müemlékei I. Budapest, 1986. 92-114.

Dókus 1900 Dókus Gyula: Árpádkori sírleletek Zemplén vármegyében. Archaeologiai Értesítő 20. 39-61.

DuŠEk 1955 Dušek, Mikuláš: Kostrové pohrebište z X. a XI. storočie v Chotine na Slovensku. Slovenská archeológia 3. $244-263$.

EIsNer 1935 Eisner, Jan: Prehistorický výskum na Slovensku a Podkarpatské Rusi roku 1934. Sbornik Muzealnej Slovenskej Spoločnosti 29.51-80.

ÉRDY 1858 Érdy János: A verebi pogánysír. M. t. akadémia Évkönyvei 9. 14-27.

ÉRY 1967-68 Éry Kinga: Reconstruction of the tenth century population of Sárbogárd on the basis of archaeological and anthropological data. Alba Regia 8-9.93-147.

FARKAS 1892 Farkas Sándor: Népvándorláskori temető Mártélyon. Archaeologiai Értesítő 12. 413-422.

Fehér - ÉRY - Kralovánszky 1962 Fehér Géza - Éry Kinga - Kralovánszky Alán: A Közép-Duna-medence magyar honfoglalás-és kora Árpád-kori sírleletei. Régészeti Tanulmányok 2. Budapest, 1962.

FEтTICH 1931 Fettich Nándor: Adatok a honfoglaláskor archaeologiájához (Zur Archäologie der ungarischen Landnahmezeit). Archaeologiai Értesítő 45. 48-112, 305-329.

FEтTICH 1937 Fettich Nándor: A honfoglaló magyarság fémművessége (Die Metallkunst der landnehmenden Ungarn). Archaeologia Hungarica 21. Budapest, 1937.

FEттісH 1943 Fettich Nándor: Győr története a népvándorlás korban. Győr, 1943.

FoDOR 1973 Fodor István: Honfoglaláskori művészetünk iráni kapcsolatainak kérdéséhez (On the problem of the influence of Iranian art upon Hungarian art in the conquest period- 10th century). Archaeologiai Értesítő 100. 32-41.

FODOR - KERTÉSz 2015 Fodor István - Kertész Róbert: Honfoglalás kori sír Tiszapüspöki határában (A conquest period burial on the outskirts of Tiszapüspöki). Archaeologiai Értesítő 140. 257-263.

Galuina - VARGa 2016 Gallina Zsolt - Varga Sándor: A Duna-Tisza közének honfoglalás és kora Árpád-kori temetői, sír- és kincsleletei l. A kalocsai Sárköz a 10-11. században. Szeged-Budapest, 2016.

GÁDOR 1969 Gádor Judit: Sóshartyán-Zudó tető. Régészeti Füzetek Ser. 1/22. 51-52.

GÁl 2013 Gáll Erwin: Az Erdélyi-medence, a Partium és a Bánság 10-11. századi temetői. Szeged, 2013.

GIESLER 1981 Giesler, Jochen: Untersuchungen zur Chronologie der Bijelo Brdo-Kultur. Praehistorische Zeitschrift 56. 3-167.

GöMÖRI 1984 Gömöri János: XI. századi temető Szakonyban (Ein Gräberfeld aus dem XI. Jh. in Szakony). Communicationes Archaeologicae Hungariae 1984. 81-108.

HAMPEL 1892 Hampel József: A N. Múzeumi régiségtár gyarapodása. Archaeologiai Értesítő 12. 372-380.

Hampel 1894 Hampel József: A régibb középkor (IV-X. század) emlékei Magyarhonban I. rész. Budapest, 1894.

Hampel 1896/1900 Hampel József: A honfoglalási kor hazai emlékei. In: Pauler Gyula - Szilágyi Sándor (szerk.): A magyar honfoglalás kútföi. Budapest, 1896/1900. 505-878.

Hampel 1897 Hampel József: A régibb középkor (IV-X. század) emlékei Magyarhonban. 2. rész. Budapest, 1897.

HAMPEL 1905 Hampel, József: Alterthümer des frühen Mittelalters in Ungarn I-III. Braunschweig, 1905.

HAMPEL 1907 Hampel József: Újabb tanulmányok a honfoglalási kor emlékeiről. Budapest, 1907.

Hanulıak 1993 Hanuliak, Milan: Archeologický výskum k dejinam Nitry v 10-13. storoči. In: Pieta, Karol (ed.): Nitra. Príspevky k najstaršim dejinam mesta. Nitra, 1993. 109-124.

Hanulıak 1994 Hanuliak, Milan: Malé Kosihy I. Pohrebisko z 10.-11. storočia (archeologicko-historické vyhodnoténie). Nitra, 1994. 
HEGYI - KöLTŐ 2017 Hegyi Borbála - Költő László: Vörs-Majori-dűlő 10-11. századi temetője (The $10^{\text {th }}-11^{\text {th }}$ century cemetery at Vörs-Majori-dűlő). In: Türk Attila (szerk.): Hadak Útján 24/2. A népvándorláskor fiatal kutatóinak XXIV. konferenciája.

Budapest-Esztergom, 2017. 597-626.

HOREDT 1958 Horedt, Kurt: Untersuchungen zur Frühgeschichte Siebenbürgens. Bukarest, 1958.

HoRvÁTH 2014 Horváth Ciprián: Győr és Moson megyék honfoglalás és kora Árpád-kori temetői és sírleletei. Szeged, 2014.

IsTVÁNOVITS 2003 Istvánovits Eszter: A Rétköz honfoglalás és kora Árpád-kori leletanyaga. Nyíregyháza-Budapest, 2003.

JAKAB 2014 Jakab Attila: A tiszadob-sós-széki 10. századi temetőrészlet. In: Tóth Anikó: A nyíri Mezőség a 10-11. században. Szeged, 2014. 277-298.

JAKAB 2017 Jakab Attila: Görög feliratos honfoglalás kori gyűrű a Nyírségből. Határtalan Régészet 2017/4. 46-49.

JósA 1896 Jósa András: A bezdédi honfoglaláskori temető. Archaeologiai Értesítő 16. 385-412.

JósA 1914 Jósa András: Honfoglaláskori leletek Szabolcsban. Archaeologiai Értesítő 34. 169-184, 303-340.

Jotov - AtanAsov 1998 Йотов, Валери - Атанасов, Георги: Скала. Крепост om X-ХІ век до с. Кладенци, Тервелско. Szófia, 1998.

JuHÁsz 1978 Juhász Irén: Szarmata temető Endréden (Sarmatisches Gräberfeld in Endrőd). Békés Megyei Múzeumok Közleményei 5. 87-114.

KADA 1912 Kada Elek: Kecskemét vidékéről való leletek. Ferencszállási lelet. Archaeologiai Értesítő 32. 323-329.

KARÁCSONYI 1903 Karácsonyi János: A bihari honfoglaláskori lovas-sírokról. Archaeologiai Értesítő 23. 66-67, 405-412.

KATALÓGUs 1996 Fodor István (szerk.): A honfoglaló magyarság. Kiállítási katalógus. Budapest, 1996.

Katalógus 1997 Evans, Helen C. - Wixom, William D. (ed.): The Glory of Byzantium. Art and Culture of the Middle Byzantine Era. A.D. 843-1261. New York, 1997.

KESZI 1999 Keszi Tamás: 10. századi zárt lemezgyűrűk pajzs alakúan kiszélesedő fejjel, pentagramma és madár ábrázolással (Geschlossene Plattenringe aus X. Jahrhundert mit schildförmig ausgebreitetem Kopf, mit Darstellung von Pentagramma und Vogel). In: S. Perémi Ágota (szerk.): A népvándorláskor fiatal kutatói 8. találkozójának elöadásai. Veszprém, 1999. 133-148.

KIss 1985 Kiss, Attila: Studien zur Archäologie der Ungarn im 10. und 11. Jahrhundert. In: Friesinger, Herwig - Daim, Falko (Hrsg.): Die Bayern und ihre Nachbarn. Teil 2. Wien, 1985. 217-378.

Kıss 2000 Kiss Gábor: Vas megye 10-12. századi sír-és kincsleletei. Szombathely, 2000.

Kıss 1920-1922 Kiss Lajos: Eperjeskei honfoglaláskori temető. Archaeologiai Értesítő 39. 43-55.

Kıss 1937 Kiss Lajos: Honfoglaláskori sírok Tiszabercelen (Gräber aus der Landnahmezeit in Tiszabercel). Dolgozatok 13. 240-245.

Kıss 1938 Kiss Lajos: A geszterédi honfoglaláskori sírlelet (Das altungarische Grabfund von Geszteréd). Archaeologia Hungarica 24. Budapest, 1938.

Kovács 1984 Kovács László: A Hajdúböszörmény-Erdős tanyai honfoglaló sírlelet (Der landnahmezeitliche ungarische Grabfund von Hajdúböszörmény-Erdős tanya). Hajdúsági Múzeum Évkönyve 5. 19-53.

KovÁcs 1989 Kovács László: A nagyhalász-zomborhegyi 10. századi magyar temetőrészlet (Ungarischer Friedhofsteil von Nagyhalász-Zomborhegy aus dem 10. Jahrhundert). Communicationes Archaeologicae Hungariae 1989. 165-176.

Kovács 1993 Kovács László: A Móra Ferenc Múzeum néhány régi, honfoglalás kori leletanyagáról: Oroszlámos, Horgos, Majdán, Rábé,(Csóka) (Zu einigen alten, landnahmezeitlichen Fundmaterialien des Móra Ferenc Muzeums: Oroszlámos, Horgos, Majdán, Rábé, (Csóka)). A Móra Ferenc Múzeum Évkönyve 1991/92-1. (1993) 37-74.

KovÁCs 2011a Kovács László: Egy-egy apró 10. és 11. századi temetőmaradvány: Gyomaendrőd-Kádár-tanya, Gyomaendrőd-Ugari-dűlő I. In: Kővári Klára - Miklós Zsuzsa (szerk.): „Fél évszázad terepen” Tanulmánykötet Torma István tiszteletére 70. születésnapja alkalmából. Budapest, 2011. 287-301.

Kovács 2011 b Kovács László: A magyar kalandozások zsákmányáról (Über die Beute der ungarischen Streifzüge). Budapest, 2011.

Kovács 2015 Kovács László: A Takta-köz 10-11. századi sír- és szórványleletei, valamint a tiszalúc-sarkadi 11. századi temető. Szeged-Budapest, 2015.

Kovalovszkı 1960 Kovalovszki Júlia., A szarvasi honfoglaláskori ezüst karperec (Das Silberarmband von Szarvas aus der Zeit der Landnahme). Folia Archaeologica 12. 173-182.

KöHEGYI 1980 Kőhegyi Mihály: Das landnahmezeitliche Gräberfeld vom Madaras (Komitat Bács-Kiskun). Acta Archaeologica Hungaricae 22. 205-239.

KöLtő - SzENTPÉTERI 2001 Költő László - Szentpéteri József: Gondolatok az avar-magyar asszimilációról temetőelemzések alapján. In: Kiss Magdolna - Lengvári István (szerk.): „Együtt a Kárpát-medencében”. A népvándorlás fiatal kutatóinak VII. összejövetele. Pécs 1996. szeptember 27-29. Pécs, 2001. 119-134. 
KralovÁnszky 1967-68 Kralovánszky Alán: A móri és szabadegyházi honfoglaláskori temetkezések (Die landnahmezeitlichen Bestattungen von Mór und Szabadegyháza). Alba Regia 8-9. 249-52.

KRECSMARIK 1913 Krecsmarik Endre: A békésszentandrási honfoglaláskori jellegű temetkező helyről. Archaeologiai Értesítő 33. 27-37.

KüRTI 1973 Kürti Béla: Mezőberény területének története a honfoglalásig. In: Szabó Ferenc - Szilágyi Miklós (szerk.): Mezőberény története. Mezőberény, 1973. 17-69.

KüRTI 1978-79 Kürti Béla:Honfoglalás kori magyar temetőSzeged-Algyőn (Ein ungarisches Gräberfeld aus der Landnahmezeit in Szeged-Algyő). A Móra Ferenc Múzeum Évkönyve 1978-79/1. (1980) 323-347.

KüRTI 1983 Kürti Béla: A honfoglalás, megtelepülés, államalapítás (895-kb.1030) (Szegfü Lászlóval). In: Kristó Gyula (szerk.): Szeged története I. Szeged, 1983. 221-277.

KüRTI 1996 Kürti Béla: A honfoglaló magyar női viselet (Leletek és rekonstrukciók) (Die Frauentracht der landnehmenden Ungarn. Funde und Rekonstruktionen). In: Wolf Mária - Révész László (szerk.): A magyar honfoglalás korának régészeti emlékei. Miskolc, 1996. 148-161.

LAKATOS 2003 Lakatos Attila: 10-11. századi temető Köröstarján-Csordásdombon (Tarian, Romania) (Cemetery of the $10-11^{\text {th }}$ centuries at Köröstarján-Csordásdomb). Archaeologiai Értesítő 128. 211-226.

LANGó 2000 Langó Péter: Megjegyzések a Kárpát-medence X-XI. századi huzalkarpereceinek és sodrott karpereceinek viseletéhez és használati idejéhez (Beiträge zur Tracht und Benutzungszeit der Draht- und gedrehten Armringe im Karpatenbecken des 10.-11. Jahrhunderts). Jósa András Múzeum Évkönyve 42. 33-57.

LANGó 2012 Langó Péter: Notes on the dating of Byzantine coin finds from 10th century context in the Carpatian Basin. In: Tobias, Bendeguz (Hrsg.): Die Archäologie der frühen Ungarn. Chronologie, Technologie und Methodik. RGZM - Tagungen Bd. 17. Mainz, 2012. 49-66.

LANGó 2014 Langó Péter: Egyedi függő Kiszombor B lelőhelyről (A unique earring from the Kiszombor B site). Anders Alexandra - Balogh Csilla - Türk Attila (szerk.): Avarok pusztái. Régészeti tanulmányok Lőrinczy Gábor 60. születésnapjára. Budapest, 2014. 427-438.

LÁszLó 1943 László Gyula: A koroncói lelet és a honfoglaló magyarok nyerge (Der Grabfund von Koroncó und der altungarische Sattel). Archaeologia Hungarica 27. Budapest, 1943.

LÁszló 1943a. László Gyula: A honfoglaló magyarok müvészete Erdélyben. Kolozsvár, 1943.

LÁszLó 1944 László Gyula: A honfoglaló magyar nép élete. Budapest, 1944.

LÁszló é.n. László Gyula: A népvándorláskor müvészete Magyarországon. Budapest, é. n. (1970)

LÁszló 1988 László Gyula: Árpád népe. Budapest, 1988.

LeHoczky 1870 Lehoczky Tivadar: A szolyvai hun sír. Archaeologiai Értesítő 3. 201-206.

LeHoczky 1886 Lehoczky Tivadar: A szolyvai sírról. Archaeologiai Értesítő 6. 279-280.

Madaras 1979 Madaras László: Szolnok-Szanda, Kiss János u. 11. Régészeti Füzetek Ser. 1/32. 81.

MADARAS 2006 Madaras László: Honfoglalás kori temető Szolnok határában (Gräberfeld Szolnok-Szanda, Beke Pál-halma aus dem 10. Jahrhundert). Communicationes Archaeologicae Hungariae 2006. 213-251.

MAROSI 1914 Marosi Arnold: A székesfehérvári múzeum honfoglalás és Árpád-kori régiségei. Archaeologiai Értesítő 34. 60-63.

MARosı 1935 Marosi Arnold: Ősmagyar temető Igaron. Székesfehérvári Szemle 5. 81-88.

MARosi 1936 Marosi Arnold: Adatok Fejér megye honfoglaláskori archaeologiájához. Székesfehérvári Szemle 6. 43-48.

MeDGYESI 1995 Medgyesi Pál: Avar kori sírlelet (?) és 10-11. századi magyar köznépi temető részletei Gyulavarsánd-Laposhalomról (Awarenzeitlicher Grabfund und Teile eines ungarischen Gräberfeldes aus dem 10.-11. Jahrhundert von Gyulavarsánd-Laposhalom). In: A népvándorláskor fiatal kutatóinak IV. összejövetele. Altum Castrum IV. Visegrád, 1995. 98-118.

MEGAY 1956 Megay Géza: A miskolc-repülőtéri honfoglaláskori magyar temető. A Miskolci Herman Ottó Múzeum Közleményei 4. 14-21.

MegAY 1963 Megay Géza: A mezőzombor-bálványdombi honfoglaláskori magyar temető (Das landnahmezeitliche ungarische Gräberfeld von Mezőzombor-Bálványdomb). A Herman Ottó Múzeum Évkönyve 3. 37-53.

MesterHÁzy 1965 Mesterházy Károly: Beszámoló az 1965. évi biharkeresztes-ártándi ásatásról (Excavations at Biharkeresztes-Ártánd in the year 1965). A Debreceni Déri Múzeum Évkönyve 1965. 61-67.

MeSTERHÁZY 1968 Mesterházy Károly: Adatok a honfoglalás kori magyar köznépi család szerkezetéhez (Some facts on the structure of Hungarian commonalty joint families at the time of the conquest). A Debreceni Déri Múzeum Évkönyve 1966-67 (1968) 131-178. 
MESTERHÁZY 1978 Mesterházy Károly: A sárrétudvari (biharudvari) X-XI. századi temetők (Begräbnisstätten aus dem 10. und 11. Jahrhundert in Sárrétudvari/Biharudvari). A Bihari Múzeum Évkönyve 2. 29-44.

MESTERHÁZY 1977 Mesterházy Károly: A honfoglaló magyarok tárgyi emlékei. Életünk 1977/1. 30-67.

MESTERHÁzy 2006 Mesterházy, Károly: Die Kunst der landnehmenden Ungarn im Kraftfeld der iranischen, byzantinischen und islamischen Welt. In: Gálik, Marian - Štefanovičová, Tatiana (ed.): Trade, journeys, inter- and intracultural communication in East and West (up to 1250). Bratislava, 2006. 218-231.

MESTERHÁZY 2013 Mesterházy Károly: A honfoglaló magyarok aranya (Hungarian gold at the time of the landnahm (10 th century). Tisicum 22. 203-213.

MÉszÁros 1962 Mészáros Gyula: Honfoglaláskori sírlelet Nagyszokoly határából (Grabfund der Landnahmezeit aus dem Dorf Nagyszokoly). A szekszárdi Balogh Ádám Múzeum Tudományos Füzetei 2. Szekszárd, 1962.

MRT 1966 Bakay Kornél - Kalicz Nándor - Sági Károly: Veszprém megye régészeti topográfiája. A keszthelyi és tapolcai járás. Magyarország Régészeti Topográfiája 1. Budapest, 1966.

MRT 1969 Éri István - Kelemen Márta - Németh Péter - Torma István: Veszprém megye régészeti topográfiája. A veszprémi járás. Magyarország Régészeti Topográfiája 2. Budapest, 1969.

MRT 1972 Dax Margit - Éri István - Mithay Sándor - Palágyi Sylvia - Torma István: Veszprém megye régészeti topográfiája. A pápai és a zirci járás. Magyarország Régészeti Topográfiája 4. Budapest, 1972.

MRT 1979 Horváth István - H. Kelemen Márta - Torma István: Komárom megye régészeti topográfiája. Esztergom és a dorogi járás. Magyarország Régészeti Topográfiája 5. Budapest, 1979.

MRT 1982 Ecsedy István - Kovács László - Maráz Borbála - Torma István: Békés megye régészeti topográfiája. A szeghalmi járás. Magyarország Régészeti Topográfiája 6. Budapest, 1982.

MRT 1998 Jankovich B. Dénes - Medgyesi Pál - Nikolin Edit - Szatmári Imre - Torma István: Békés megye régészeti topográfiája. Békés és Békéscsaba környéke. Magyarország Régészeti Topográfiája T 10. Budapest 1998.

NAGY 1892 Nagy Géza: A magyar pogánykor emlékei Fejér megyében. Archaeologiai Értesítő 12. 299-315.

NAGY 1893 Nagy Géza: A magyarhoni lovassírok. Archaeologiai Értesítő 13. 223-234.

NeEs 1932-33 Nees, Mechthildis: A tibolddaróci kincslelet (Ein Depotfund aus Tibolddaróc). Archaeologiai Értesítő 46. $164-174$.

Nemejcová-Pavuková 1962 Nemejcová-Pavuková, Viera: Belobrdské pohrebisko v Rovinke, okres Bratislava-Vidiek (Bjelo-Brdo-Gräberfeld in Rovinka, in der Umgebung von Bratislava). Archeologické Rozhledy 14. 657-669.

NÉMETH 1996 Németh Péter: A honfoglalás kor (X. század) régészeti kutatásának története. In: KATALÓGUs 1996. 19-26.

M. NepPer 2002 M. Nepper Ibolya: Hajdú-Bihar megye 10-11. századi sírleletei I-II. Budapest-Debrecen, 2002.

NevizÁnsZky 1979 Nevizánszky Gábor: Pohrebisko z konca 9. a z 10. storočia v Bešeňove. Slovenská archeológia 27. 375-404.

NEVIZÁNSZky 2013 Nevizánszky Gábor:Egyújabb honfoglalás koritemetőazAlsó-Garammentén (Ein neuereslandnahmezeitliches Gräberfeld am unteren Teil des Flusses Garam). In: Révész László - Wolf Mária (szerk.): A honfoglalás kor kutatásának legújabb eredményei. Tanulmányok Kovács László 70. születésnapjára. Szeged, 2013. 185-202.

NEVIZÁNSZky - KoŠTA 2009 Nevizánszky, Gábor - Košta, Jiři: Výskum staromad'arského jazdeckého pohrebiska v Strede nad Bodrogom v rokoch 1926 a 1937. Slovenská archeológia 57. 301-354.

NeVIZÁNSZKY - RATIMORSKA 1991 Nevizansky, Gabriel - Ratimorska, Priska: Staromadarské kostrové pohrebiska z 10. storočia v Nesvadoch. Archeologické Rozhledy 43. 259-280.

NovÁkı 1959 Nováki Gyula: Veszkény-Tormostyán dűlő. Régészeti Füzetek Ser. 1/11. 53.

NYÁRY 1902 Nyáry Albert: Temető királyságunk első századából. Archaeologiai Értesítő 22. 210-240.

ÓDOR 1999 Ódor János: Honfoglalás- és kora Árpád-kori soros temetők sírleleteinek katasztere Tolna megyében. A Wosinsky Mór Megyei Múzeum Évkönyve 21. 151-171.

PATAKI 1939 Pataki Vidor: A hevesi honfoglaláskori női sírlelet (Der Grabfund von Heves aus der Landnahmezeit). Folia Archaeologica 1-2. 200-208.

PataY 1957 Patay Pál: Adatok a nógrádi dombvidék X-XI. századi településtörténetéhez (Contributions a l'histoire du peuplement aux Xe et Xle siecles, de la region de collines de Nógrád). Archaeologiai Értesítő 84. 58-66.

PÁrducz 1943 Párducz Mihály: Árpádkori temető Hódmezővásárhely-Kopáncson (Gräberfeld der Árpádenzeit in Hódmezővásárhely-Kopáncs). Dolgozatok 19. 183-192

PÁrducz - TARY 1939 Párducz Mihály - Tary László: A csongrád-vendelhalmi honfoglaláskori lelet (Les trouvailles de Csongrád-Vendelhalom de l'epoque de la conquete du pays hongrois). Folia Archaeologica 1-2. 189-199.

PeRÉmI 1986 Perémi Ágota: Honfoglaláskori leletek Veszprém megyében (Funden aus der Zeit der Landnahme im Komitat Veszprém). Veszprém Megyei Múzeumok Közleményei 18. 115-133. 
PeRÉm 2001 Perémi Ágota: A Várpalota-Semmelweis utcai honfoglaláskori köznépi temető (Ein Volksfriedhof aus der Zeit der ungarischen Landnahme an der Semmelweis-Strasse in Várpalota). In: Kiss Magdolna - Lengvári István (szerk.): „Együtt a Kárpát-medencében". A népvándorlás fiatal kutatóinak VII. összejövetele. Pécs 1996. szeptember 27-29. Pécs, 2001. 137-213.

Poulou-Papadimitriou - Tzavella - Ot 2012 Poulou-Papadimitriou, Natalia - Tzavella, Elli - Ott, Jeremy: Burial practices in Byzantine Greece: archaeological evidence and methodological prblems for its interpretation. In: Salamon, Maciej - Woloszyn, Marcin - Musin, Alexander - Spehar, Perica (ed.): Rome, Constantinople and Newly-Converted Europe. Archaeological and Historical Evidence. I. Krakow-Leipzig-Rzeszów-Warszawa, 2012. 377-428.

PóstA 1896 Posta Béla: A törteli magyar pogánykori leletek. Archaeologiai Értesítő 16. 30-39.

Pulszky 1891 Pulszky Ferenc: A magyar pogány sírleletek. Értekezések a történelmi tudományok köréből 14. 1891. 1-21.

Pusztal 1969 Pusztai Rezső: Pusztasomorja-Tímárdomb. Régészeti Füzetek Ser. 1/22. 67.

ReiHolcova 1976 Reiholcová, Maria: Pohrebisko z 10. a 11. storočia v Hurbanove-Bohatej. Slovenská archeológia 24. $191-234$.

Reirolcová 1995 Reiholcová, Maria: Pohrebisko v Čakajovciach (9.-12. storočie). Katalog. Nitra, 1995.

REIZNER 1891 Reizner János: Magyar pogánykori sírleletek (Szeged-Királyhalmi és Bojárhalmi lelet). Archaeologiai Értesítő 11. 97-114.

RÉTHY 1898 Réthy László: Két Árpád-kori temető Arad megyében. Archaeologiai Értesítő 18. 128-131.

RÉvÉsz 1992 Révész László: Honfoglalás és államalapítás kori temetők Miskolcon (Friedhöfe aus der Zeit der Landnahme und der Staatsgründung in Miskolc). In: Rémiás Tibor (szerk.): Régészeti tanulmányok Miskolc korai történetéből. Miskolc, 1992. 91-120.

RÉvész 1996a Révész László: Honfoglalás kori temető Szentes-Borbásföldön (Szabó János Győző ásatása nyomán) (Ein landnahmezeitliches Gräberfeld in Szentes-Borbásföld, nach der Ausgrabung von J. Gy. Szabó). A Móra Ferenc Múzeum Évkönyve - Studia Archaeologica 2. 299-336.

RÉvész 1996b Révész László: A karosi honfoglalás kori temetők. Régészeti adatok a Felső-Tisza-vidék X. századi történetéhez (Die Gräberfelder von Karos aus der Landnahmezeit). Miskolc, 1996.

RÉvész 1997 Révész László: Ein landnahmezeitliches Frauengrab in Békéscsaba-Erzsébethely. Acta Archaeologica Hungaricae 49. 419-451.

RÉvész 2008 Révész László: Heves megye 10-11. századitemetői (Die Gräberfelder des Komitates Heves im 10-11. Jahrhundert). Budapest, 2008.

Roska 1914 Roska Márton: Árpádkori sírok Várfalván (Cimitiere l'epoque des Árpádes á Várfalva). Dolgozatok 5. 121-168, 169-187.

Roska 1936 Roska Márton: A honfoglalás és Erdély. In: Asztalos Miklós (szerk.): A történeti Erdély. Budapest, 1936. $163-173$.

Ross 1965 Ross, Marvin C.: Catalogue of the Byzantine and early medieval antiquities in the Dumbarton Oaks Collection. I-II. Washington, 1962/1965.

Ross - Downey 1956-57 Ross, Marvin C. - Downey, Glanville: An Emperor's Gift and Notes on Byzantine Silver Jewelry of the Middle Period. The Journal of the Walters Art Gallery 19-20. 22-33.

SeLMECZI 1996 Selmeczi László: A Tiszajenő-Eperjesi telepi honfoglalás kori temető (Der Begräbnisplatz einer Siedlung aus der Zeit der Landnahme in Tiszajenő-Eperjes). In: Wolf Mária - Révész László (szerk.): A magyar honfoglalás korának régészeti emlékei. Miskolc, 1996. 117-121.

SÖREGI 1948 Sőregi János: Jelentés az 1947. évről. Debreceni Déri Múzeum Évkönyve 1943-47. 4-8.

Stefan - BARneA - Comsa - Comsa 1967 Stefan, Gheorghe - Barnea, lon - Comsa, Maria - Comsa, Eugen: Dinogetia I. Asezarea feudala timpurie de la Bisericuta-Garvan. Bibliotheca de Arheologie 13. Bukarest, 1967.

Straub 1999 Straub Péter: A honfoglalás kori tegezcsontok időrendjéhez (Zur Chronologie der landnahmezeitlichen Knöcherknochen). A Móra Ferenc Múzeum Évkönyve - Studia Archaeologica 5. 409-422.

SuPKA 1911 Supka Géza: Honfoglaláskori leletről Gödöllőn. Archaeologiai Értesítő 31. 180-182.

SzABó 1978-79 Szabó János Győző: Árpád-kori telep és temetője Sarud határában (Árpádenzeitliche Siedlung und ihr Friedhof in der Gemarkung von Sarud). Egri Múzeum Évkönyve 16-17. 45-136.

SzABó 1938 Szabó Kálmán: Az alföldi magyar nép művelődéstörténeti emlékei (Kulturgeschichtliche Denkmäler der ungarischen Tiefebene). Bibliotheca Humanitatis Historica 3. Budapest, 1938.

SzABó 1955 Szabó Kálmán: Honfoglaláskori párták (Девичие головные уборы периода занятия родины). Folia Archaeologica 7. 123-125.

SZARIANIDI 1983 Сарианиди, Виктор Иванович: Афганистан: сокровища безымянных царей. Moszkva, 1983.

Szedov 1982 Седов, Валентин Васильевич: Востточные славяне в VI-ХIII вв. Археолология CCCP. Moszkva, 1982. 
SzélL 1940 Széll Márta: Elpusztult falvak, X-XVI. századbeli régészeti leletek Szeged és Hódmezővásárhely határában. Dolgozatok 16. 159-180.

SzÉLL 1941 Széll Márta: XI. századi temetők Szentes környékén. Folia Archeologica 3-4. 231-265.

SzélL 1942 Széll Márta: Elpusztult falvak, XI-XII. századbeli régészeti leletek Szentes határában. Dolgozatok 18. $128-134$.

SzŐKE 1941 Szőke Béla: Honfoglaláskori magyar sírok Naszvadon (Gräber der ungarischen Landnahmezeit in Naszvad). Folia Archaeologica 3-4. 214-222.

SzŐKE 1954 Szőke Béla: Adatok a Kisalföld IX. és X. századi történetéhez. Archaeologiai Értesítő 81. 119-137.

SzŐKE 1962 Szőke Béla: A honfoglaló és kora Árpád-kori magyarság régészeti emlékei. Régészeti Tanulmányok 1. Budapest, 1962. Sztanojev 1989 Stanojev, Nebojsa: Nekropolen aus dem 10.-15. Jahrhundert in der Vojvodina. Novi Sad, 1989.

TerGINA 1880 Tergina Gyula: Az ordasi lelet. Archaeologiai Értesítő XIV. 336-340.

TALICKIJ 1940 Талицкий, М. В.: Кочергинский могильник. МИА 1. 159-163.

Točık 1968 Točik, Anton: Altmagyarische Gräberfelder in der Südwestslowakei. Bratislava, 1968.

Točı 1971 Točik, Anton: Flachgräberfelder aus dem IX. und X. Jh. in der Südwestslowakei. Slovenská archeológia 19. 135-276.

Točık 1992 Točik, Anton: Materialy k dejinam južného Slovenska v 7.-14. storoči (Materialien zur Geschichte der Südwestslowakei im 7.-14.Jahrhundert). Študijné Zvesti AUSAV 28. 5-248.

Tóтн 2014 Tóth Anikó: A nyíri Mezőség a 10-11. században. Szeged, 2014.

Türk 2014 Türk Attila: A honfoglalás kori régészeti hagyatékkal kapcsolatot mutató keleti lelőhelyek. In: Sudár Balázs - Petkes Zsolt (szerk.): A honfoglalók viselete. Budapest, 2014. 36-64.

TüRK - LőRINCZY 2015 Türk Attila - Lőrinczy Gábor: Régészeti adatok és természettudományi eredmények a Maros-torkolat nyugati oldalának 10. századi történetéhez. Budapest, 2015.

VARÁZsÉJl 1880 Varázséji Gusztáv: A szeged-öthalmi őstelep és temető. Archaeologiai Értesítő XIV. 323-336.

K. VÉGH 1970 K. Végh Katalin: Honfoglalás- és kora Árpád-kori sírleletek a miskolci múzeumban (Landnahme- und frühárpádenzeitliche Grabfunde im Miskocer Museum). A Herman Ottó Múzeum Évkönyve 9. 79-107.

K. VÉGH 1993 K. Végh Katalin: A kistokaji honfoglalás kori temető (Bestattungsort aus der Zeit der Landnahme in Kistokaj). A Herman Ottó Múzeum Évkönyve 30-31/1. (1991-92) 53-103.

WiNKLER 1912 Winkler Pál: Keceli sírleletek (Pest m.). Archaeologiai Értesítő 32. 322-323.

Wolf 2016 Wolf Mária: Adatok a 10. századi magyarság csontművességéhez (Data on the bone-working in tenth century Hungary). In: Kovács László - Révész László (szerk.): Népek és kultúrák a Kárpát-medencében. Tanulmányok Mesterházy Károly tiszteletére. Budapest, 2016. 649-665.

WosINSKY 1896 Wosinsky Mór: Tolnavármegye az őskortól a honfoglalásig I-II. Budapest, 1896.

YASHAYEVA 2010Yashayeva, Tatiana:Würfel. In:Daim, Falko-Fleck, Robert (Hrsg.):Byzanz, Prachtund Alltag. Ausstellungskatalog. Bonn, 2010. 208-209, No. 135.

ZolTA - SÖREG 1927 Zoltai Lajos - Söregi János: Ásatások. A hajdúböszörményi vidi pusztán. Debreceni Déri Múzeum Évkönyve 1927. 16-19. 